\author{
UNIVERSIDADE DE SÃO PAULO \\ FACULDADE DE MEDICINA DE RIBEIRÃO PRETO
}

PABLO DIEGO MOÇO

Estabelecimento de uma plataforma para produção de vetores lentivirais para modificação de linfócitos $T$ com CAR anti-CD19

Ribeirão Preto 
PABLO DIEGO MOÇO

\title{
Estabelecimento de uma plataforma para produção de vetores lentivirais para modificação de linfócitos T com CAR anti-CD19
}

\author{
Versão corrigida. A versão original encontra-se disponível tanto na Biblioteca \\ da Unidade que aloja o Programa, quanto na Biblioteca Digital de Teses e \\ Dissertações da USP (BDTD)
}

\begin{abstract}
Dissertação apresentada à Faculdade de Medicina de Ribeirão Preto da Universidade de São Paulo para obtenção do título de Mestre em Ciências.

Área de concentração: Células-Tronco e Terapia Celular

Orientadora: Profa. Dra. Virgínia Picanço e Castro
\end{abstract}

Ribeirão Preto 
Autorizo a reprodução e divulgação total ou parcial deste trabalho, por qualquer meio convencional ou eletrônico, para fins de estudo e pesquisa, desde que citada a fonte.

Moço, Pablo Diego

Estabelecimento de uma plataforma para produção de vetores lentivirais para modificação de linfócitos T com CAR antiCD19. Ribeirão Preto, 2018.

113 p. : il. ; $30 \mathrm{~cm}$

Dissertação de Mestrado, apresentada à Faculdade de Medicina de Ribeirão Preto da Universidade de São Paulo. Área de concentração: Células-tronco e Terapia Celular.

Orientadora: Castro, Virgínia Picanço e.

1. Imunoterapia. 2. Receptor quimérico de antígeno. 3. CD19. 4. Linfócitos T-CAR. 5. Vetores lentivirais. 6. Concentração. 
Nome: MOÇO, Pablo Diego

Título: Estabelecimento de uma plataforma para produção de vetores lentivirais para modificação de linfócitos T com CAR anti-CD19

Dissertação apresentada à Faculdade de Medicina de Ribeirão Preto da Universidade de São Paulo para obtenção do título de Mestre em Ciências.

Área de concentração: Células-Tronco e Terapia Celular

Aprovado em: 23 de julho de 2018

\section{Banca Examinadora}

Dr. Rodrigo do Tocantins Calado de Saloma Rodrigues

Instituição: $\quad$ FMRP - USP

Julgamento:

Dr. Cristiano Gonçalves Pereira

Instituição: FEARP - USP

Julgamento:

Dra. Carolina Caliári Oliveira

Instituição: In Situ Terapia Celular

Julgamento: 


\section{AGRADECIMENTOS}

Aos meus pais, Antônio e Maura, e irmã, Bianca, por sempre acreditarem em mim e me apoiarem em todas as minhas decisões, nem que isso significasse ficar meses sem poder visitá-los.

À minha amada Bárbara, por todo o companheirismo, amor e incentivo recebidos dia após dia.

À professora Virgínia Picanço e Castro, pela orientação no desenvolvimento deste trabalho.

A todos do grupo de CAR-T cells, Amanda Mizukami, Letícia Delfini, Marcelo Pereira, Renata Silvestre, e professoras Kamilla Swiech e Kelen Farias, por todas as contribuições a esse trabalho.

Às colegas do Laboratório de Biotecnologia e Laboratório de Transferência Gênica, Marcela Freitas, Aline Bonfim, Luiza Reis e Daianne Macielly.

A todos os pesquisadores, alunos e funcionários do Hemocentro. Em especial à Patrícia Bonini e Camila Menezes pelo auxílio na elaboração de experimentos e análises por citometria de fluxo, ao Mário Abreu por todo o suporte prestado, e à Carmen Simão por estar sempre disposta a ajudar.

À secretaria do programa, em especial à Adriana Fuzaro e ao Vinícius Godoi pela ajuda com os assuntos burocráticos relacionados ao programa.

À FAPESP (Processo número 2016/08374-5) pelo auxílio financeiro e incentivo à pesquisa.

Aos membros da banca, por se disponibilizarem a analisar este trabalho.

$E$ a todos que não nomeei, mas estiveram envolvidos direta ou indiretamente no desenvolvimento deste trabalho. 


\section{RESUMO}

MOÇO, Pablo Diego. Estabelecimento de uma plataforma para produção de vetores lentivirais para modificação de linfócitos T com CAR anti-CD19. 2018. 112 f. Dissertação (Mestrado em Oncologia Clínica, Células-Tronco e Terapia Celular) - Faculdade de Medicina de Ribeirão Preto, Universidade de São Paulo, Ribeirão Preto, 2018.

A imunoterapia utilizando linfócitos $T$ modificados com receptor quimérico de antígenos (CAR) tem se mostrado eficaz no tratamento de leucemia e linfomas resistentes à quimioterapia. A proteína CD19 é considerada um alvo ideal porque é expressa na maioria dos tumores de linfócitos $B$ e linfócitos $B$ normais, mas não em outras células. Estudos clínicos recentes mostraram excelentes respostas de linfócitos T-CAR em uma variedade de tumores de células B. Os vetores lentivirais são o método mais comumente utilizado para modificação genética em ensaios clínicos. Este estudo teve como objetivo desenvolver uma plataforma eficiente para a produção de lentivírus e testar a funcionalidade desses vetores para que possam ser usados para modificar geneticamente linfócitos T. A transfecção transiente de céulas HEK293T com plasmídeos na proporção de 3:1:1:1 (transgene:gag-pol:VSV-G:rev) utilizando lipossomos catiônicos e $5 \mathrm{mM}$ de butirato de sódio resultou nos títulos virais mais elevados. Isso representa um aumento de 17 vezes no título viral da transfecção com polietilenoimina ( $\mathrm{PEI})$. Três métodos para concentracao lentiviral foram utilzados nesse trabalho, ultracentrifugação, filtração tangencial e ultrafiltração. A ultrafiltração sobre membrana com corte de peso molecular (MWCO) de $100 \mathrm{kDa}$ resultou na maior taxa de recuperação de partículas virais viáveis, aproximadamente $82 \%$. As partículas virais produzidas por este processo demonstraram ser funcionais para a transdução de linfócitos $T$. Além disso, o receptor quimérico (CAR) se mostrou específico contra o antígeno CD19 de células B, resultando na ativação dos linfócitos T-CAR e gerando citotoxicidade contra células $\mathrm{CD} 19^{+}$in vitro. Houve uma redução de aproximadamente $87 \%$ das células alvo, quando analisado por citometria de fluxo e uma citotoxicidade média de $50 \%$ foi observada por ensaios colorimétricos.

Palavras-chave: Imunoterapia. Receptor quimérico de antígeno. CD19. Linfócitos TCAR. Vetores lentivirais. Concentração. 


\begin{abstract}
MOÇO, Pablo Diego. Establishment of a platform for the production of lentiviral vectors for the modification of anti-CD19 CAR-T cells. 2018. $112 \mathrm{f}$. Dissertação (Mestrado em Oncologia Clínica, Células-Tronco e Terapia Celular) - Faculdade de Medicina de Ribeirão Preto, Universidade de São Paulo, Ribeirão Preto, 2018.

Immunotherapy using T cells modified with chimeric antigen receptor (CAR) has been proven effective in the treatment of leukemia and lymphomas resistant to chemotherapy. CD19 protein has been shown to be an ideal target because it is expressed on most B-cell tumors and normal B cells, but not in other cells. Recent clinical studies have shown excellent responses of CAR T-cells in a variety of B-cell tumors. Lentiviral vectors are the most commonly used method for genetic modification in clinical trials. This study aimed to develop an efficient platform for lentiviral production and to test the functionality of those vectors so that they can be used in to genetically modify T cells. Transient transfection of HEK293T cells with plasmids in a 3:1:1:1 ratio (transgene:gag-pol:VSV-G:rev) using cationic liposomes and $5 \mathrm{mM}$ sodium butyrate resulted in the highest viral titers. That represents a 17-fold increase in viral titer from polyethylenimine (PEI) transfection. Three methods for lentiviral concentration were used in this work, ultracentrifugation, tangential filtration and ultrafiltration. Membrane ultrafiltration with $100 \mathrm{kDa}$ molecular weight cutoff (MWCO) resulted in the highest recovery rate of viable viral particles, approximately $82 \%$. The viral particles produced by this process have been shown to be functional for the transduction of $\mathrm{T}$ cells. In addition, the chimeric receptor (CAR) was shown to be specific against the B cell antigen CD19, resulting in the activation of CAR-T cells and generating cytotoxicity against $\mathrm{CD}^{+} 9^{+}$cells in vitro. There was a reduction of approximately $87 \%$ of the target cells when analyzed by flow cytometry and an average cytotoxicity of $50 \%$ was observed by colorimetric assays.
\end{abstract}

Keywords: Immunotherapy. Chimeric antigen receptor. CD19. CAR-T cells. Lentiviral vectors. Concentration. 


\section{LISTA DE FIGURAS}

Figura 1 - Estrutura básica de um receptor quimérico de antígenos (CAR) .............19

Figura 2 - Evolução dos receptores quiméricos de antígeno...................................20

Figura 3 - Expressão de marcadores de superfície em linfócitos B e neoplasias

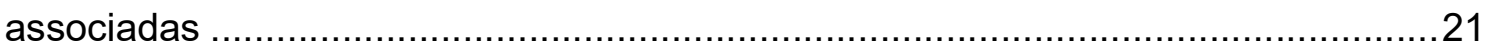

Figura 4 - Representação esquemática de vetores derivados do HIV-1 ….............27

Figura 5 - Fluxograma ilustrativo das etapas de desenvolvimento do projeto ............35

Figura 6 - Esquema dos vetores utilizados na produção viral através da co-transfecção

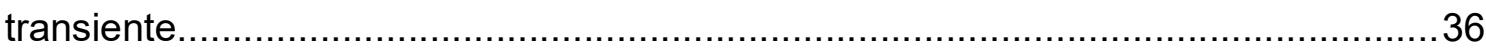

Figura 7 - Visualização dos fragmentos gerados após digestão enzimática dos vetores

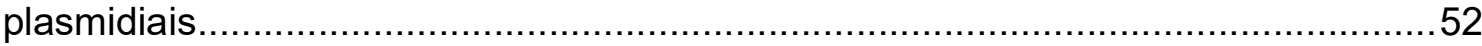

Figura 8 - Comparação dos métodos de cálculo do título viral ................................53

Figura 9 - Efeito do tempo de coleta do sobrenadante viral ..................................54

Figura 10 - Efeito da proporção de plasmídeos na produção viral ..........................55

Figura 11 - Efeito do Butirato de Sódio na produção viral ........................................56

Figura 12 - Otimização da produção dos vetores lentivirais ………………….......57

Figura 13 - Recuperação de partículas virais pré e pós-concentração.......................58

Figura 14 - Rendimento de concentração dos métodos analisados .........................61

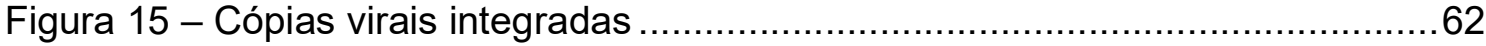

Figura 16 - Ativação das células CAR na presença do antígeno CD19 …...............63

Figura 17 - Porcentagem de células $\mathrm{CAR}^{+}$ao longo da expansão...........................64

Figura 18 - Análise de citotoxicidade celular in vitro por citometria de fluxo..............65

Figura 19 - Análise de citotoxicidade in vitro por espectrofotometria.......................66 


\section{LISTA DE TABELAS}

Tabela 1 - Terapias com linfócitos T CAR em desenvolvimento ……………….....23

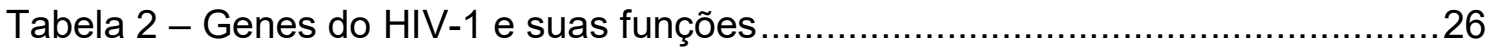

Tabela 3 - Teste QuixStand 1 - Eficiência da filtração tangencial de sobrenadante

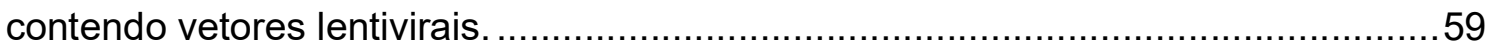

Tabela 4 - Teste QuixStand 2 - Eficiência da filtração tangencial de sobrenadante

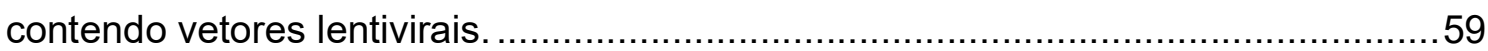

Tabela 5 - Teste QuixStand 3 - Eficiência da ultrafiltração tangencial de sobrenadante

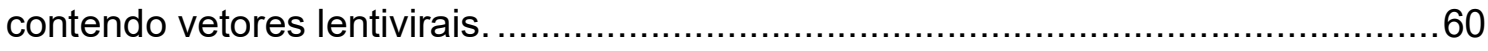

Tabela 6 - Partículas virais recuperadas após a filtração tangencial seguida de

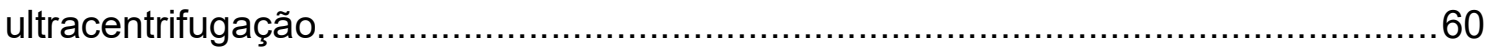

Tabela 7 - Efeito do soro no meio de transdução na eficiência de modificação de linfócitos T primários. ......................................................................................64 


\section{LISTA DE ABREVIATURAS E SIGLAS}

BMC background do meio de cultivo

CAEV caprine arthritis encephalitis virus (vírus da artrite encefalite caprina)

CAR chimeric antigen receptor (receptor quimérico de antígeno)

$\mathrm{CMV} \quad$ promotor do citomegalovírus

$\mathrm{CO}_{2}$ dióxido de carbono

CPPT central polypurine do HIV-1

CRS cytokine release syndrome (síndrome de liberação de citocina)

CTH células-tronco hematopoiéticas

CV correção de volume

$\mathrm{DEcH}$ doença do enxerto contra o hospedeiro

DMEM Dulbecco's modified Eagle's medium

DMSO dimetilsufóxido

ECA liberação espontânea de LDH pela célula alvo

ECE liberação espontânea de LDH pela célula efetora

EDTA ethylenediaminetetraacetic acid (ácido etilenodiamino tetra-acético)

eGFP enhanced green fluorescent protein (proteína verde fluorescente melhorada

EIAV equine infectious anemia virus (vírus da anemia infecciosa equina)

FcRc Fc receptor (receptor Fc)

FDA Food and Drug Administration

FITC fluorescein isothiocyanate (isotiocianato de fluoresceína)

FIV feline immunodeficiency virus (vírus da imunodeficiência felina)

$\mathrm{HCl}$ ácido clorídrico

HIV human immunodeficiency virus (vírus da imunodeficiência humana)

ITAM immunoreceptor tyrosine-based activation motif (motivo de ativação baseado em tirosina do imunorreceptor)

LB Luria Bertani

LDH lactato desidrogenase

LLA leucemia linfoide aguda

LLC leucemia linfoide crônica 


\begin{tabular}{|c|c|}
\hline LTR & long terminal region (repetição terminal longa) \\
\hline MCA & liberação máxima de LDH pela célula alvo \\
\hline $\mathrm{MgCl}_{2}$ & cloreto de magnésio \\
\hline $\mathrm{MgSO}_{4}$ & sulfato de magnésio \\
\hline $\mathrm{MHC}$ & $\begin{array}{l}\text { major histocompatibility complex (complex principal de } \\
\text { histocompatibilidade) }\end{array}$ \\
\hline $\mathrm{MOI}$ & multiplicity of infection (multiplicidade de infecção) \\
\hline MWCO & molecular weight cut-off (corte de peso molecular) \\
\hline $\mathrm{NaBu}$ & butirato de sódio \\
\hline $\mathrm{NaCl}$ & cloreto de sódio \\
\hline $\mathrm{NAD}^{+}$ & nicotinamida adenina dinucleotídeo (oxidado) \\
\hline $\mathrm{NADH}$ & nicotinamida adenina dinucleotídeo (reduzido) \\
\hline nef & negative regulatory factor (fator de regulação negativa) \\
\hline PBMC & $\begin{array}{l}\text { peripheral blood mononuclear cells (células mononucleares do sangue } \\
\text { periférico) }\end{array}$ \\
\hline PBS & phosphate buffered saline (tampão fosfato salino) \\
\hline PCR & $\begin{array}{l}\text { quantitative polymerase chain reaction (reação em cadeia da } \\
\text { polimerase) }\end{array}$ \\
\hline PEI & polietilenoimina \\
\hline qPCR & PCR quantitativo \\
\hline RPMI & Roswell Park Memorial Institute medium \\
\hline RRE & $\begin{array}{l}\text { Rev-responsive element do HIV-1 (elemento de resposta a rev do HIV- } \\
\text { 1) }\end{array}$ \\
\hline RSV & promotor do Rous sarcoma virus \\
\hline $\mathrm{scFv}$ & single-chain variable fragment \\
\hline SFB & soro fetal bovino \\
\hline SIN & self-inactivating vector (vetor autoinativante) \\
\hline SIV & simian immunodeficiency virus (vírus da imunodeficiência símia) \\
\hline SV40 & simian vacuolating virus 40 (vírus vacuolante símio 40) \\
\hline TAE & tampão Tris-EDTA acetato \\
\hline TCR & $T$ cell receptor (receptor de células $\mathrm{T}$ ) \\
\hline TIL & tumor-infiltrating lymphocyte (linfócito infiltrante de tumor) \\
\hline
\end{tabular}




\begin{tabular}{|c|c|}
\hline TM & transmembrana \\
\hline $\mathrm{V}_{\mathrm{H}}$ & região variável pesada \\
\hline vif & viral infectivity fator (fator de infectividade viral) \\
\hline$V_{L}$ & região variável leve \\
\hline$v p r$ & viral protein $R$ (proteína viral $R$ ) \\
\hline vpu & viral protein $U$ (proteína viral U) \\
\hline VSV-G & $\begin{array}{l}\text { vesicular stomatitis virus glycoprotein (glicoproteína do vírus da } \\
\text { estomatite vesicular) }\end{array}$ \\
\hline WPRE & $\begin{array}{l}\text { woodchuck hepatites virus posttranscriptional regulatory element } \\
\text { (element regulatório pós-transcricional do vírus da hepatite da } \\
\text { marmota) }\end{array}$ \\
\hline
\end{tabular}




\section{LISTA DE SÍMBOLOS E UNIDADES}

\begin{tabular}{|c|c|}
\hline$\Psi$ & sinal de empacotamento \\
\hline$\times g$ & vezes gravidade \\
\hline $\mathrm{kDa}$ & kilodalton \\
\hline TM & trademark \\
\hline$g$ & grama \\
\hline L & litro \\
\hline $\mathrm{mL}$ & mililitro \\
\hline$\mu \mathrm{L}$ & microlitro \\
\hline ng & nanograma \\
\hline $\min$ & minuto \\
\hline${ }^{\circ} \mathrm{C}$ & grau Celsius \\
\hline $\mathrm{mM}$ & milimolar \\
\hline $\mathrm{h}$ & hora \\
\hline$\mu g$ & micrograma \\
\hline $\mathrm{mg}$ & miligrama \\
\hline rpm & rotações por minuto \\
\hline $\mathrm{nm}$ & nanômetro \\
\hline (®) & marca registrada \\
\hline UI & unidade internacional \\
\hline $\mathrm{N}$ & normalidade \\
\hline $\mathrm{pb}$ & par de base \\
\hline$\mu \mathrm{m}$ & micrômetro \\
\hline TU & transfection unit (unidade infectante) \\
\hline $\mathrm{cm}^{2}$ & centímetro quadrado \\
\hline hpt & horas pós-transfecção \\
\hline $\mathrm{kb}$ & kilobase \\
\hline
\end{tabular}




\section{SUMÁRIO}

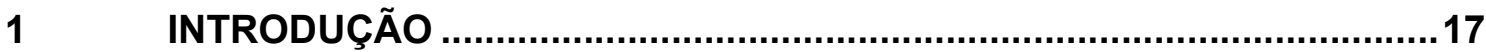

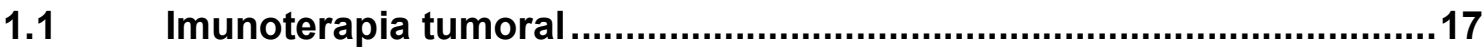

$1.2 \quad$ Receptor quimérico de antígenos ............................................................

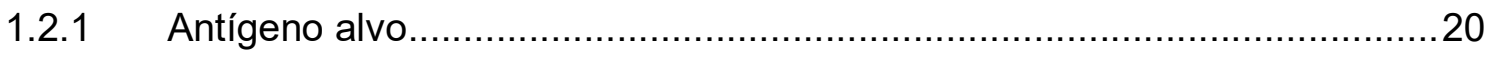

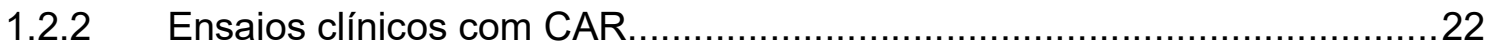

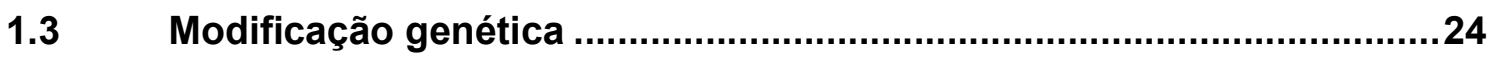

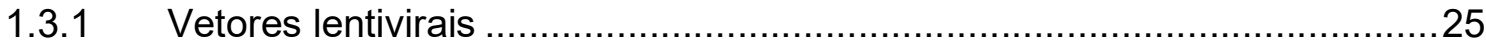

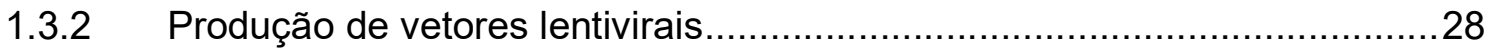

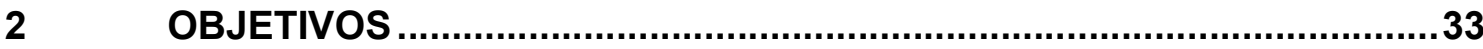

$2.1 \quad$ Objetivo geral............................................................................................

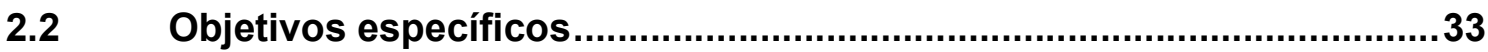

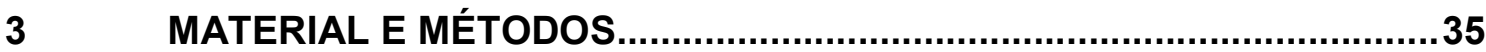

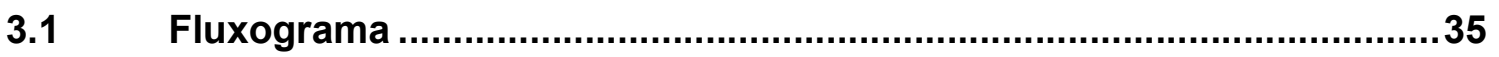

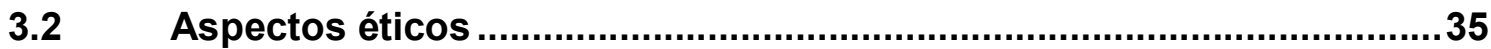

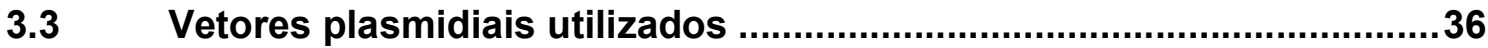

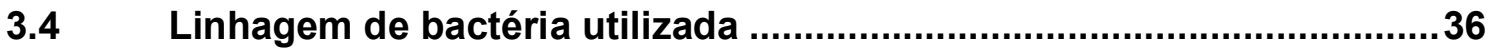

3.5 Meios para cultura de bactérias ..............................................................

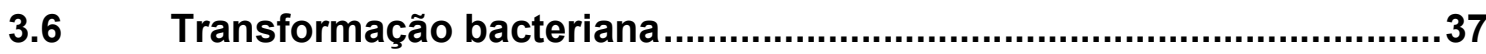

3.7 Max-preparação de plasmídeos ……...................................................37

3.8 Quantificação dos ácidos nucleicos....................................................38

3.9 Digestão enzimática do DNA plasmidial.................................................38

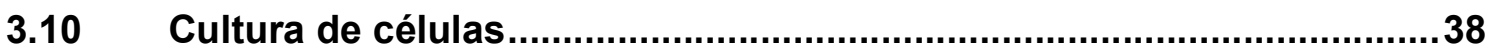

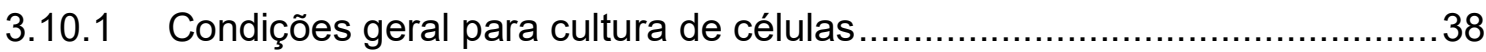

3.10.2 Cultivo de células HEK293T …………................................................

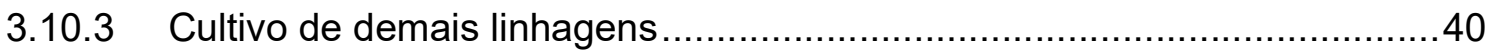

3.11 Transfecção transiente da linhagem empacotadora HEK293T ............40 
3.12 Concentração por ultracentrifugação....................................................

3.13 Concentração por filtração tangencial ...................................................41

3.14 Concentração por ultrafiltração em membrana …................................41

3.15 Rendimento de concentração ……....................................................... 42

3.16 Titulação lentiviral por PCR em tempo real........................................42

3.17 Titulação lentiviral por citometria de fluxo..............................................43

3.18 Transdução de linhagem celular .........................................................4

3.19 Ensaio de ativação de linhagem celular modificada .............................44

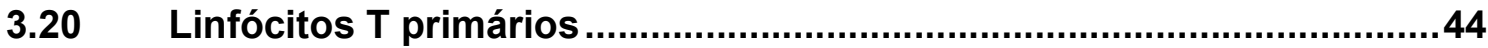

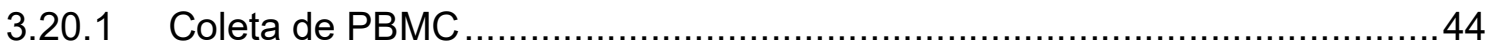

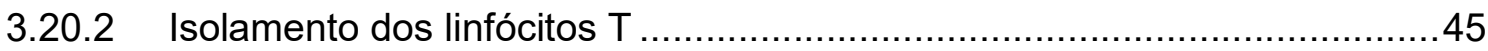

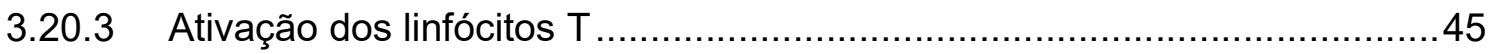

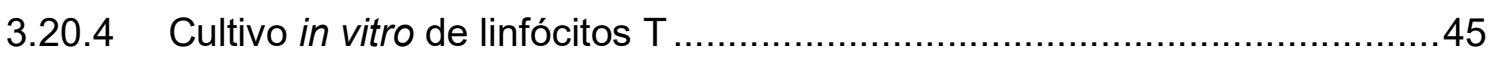

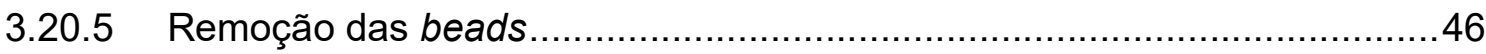

3.21 Imunofenotipagem por citometria de fluxo …......................................46

3.22 Transdução de linfócitos T primários....................................................46

3.23 Ensaio de citotoxicidade in vitro - citometria.......................................47

3.24 Ensaio de citotoxicidade in vitro - LDH .............................................47

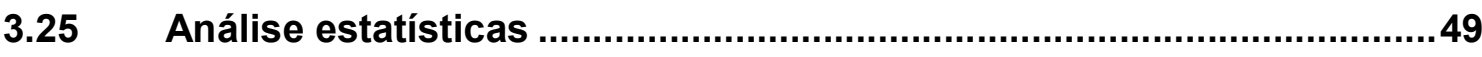

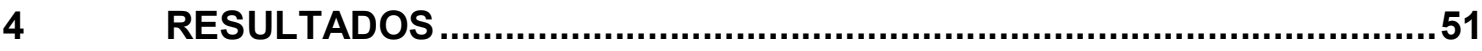

4.1 Verificação da integridade dos vetores plasmidiais .............................51

4.2 Produção das partículas lentivirais e determinação do título viral......52

4.3 Otimização da produção de vetores lentivirais para CAR anti-CD19 ..53

4.3.1 Determinação do número de coletas do sobrenadante .............................53

4.3.2 Determinação da proporção dos plasmídeos ...........................................54

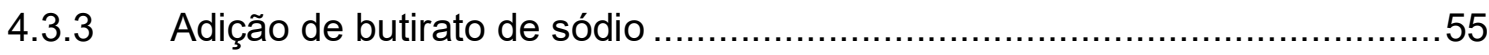

4.3.4 Transfecção transiente com lipossomo catiônico $\left(\right.$ Lipofectamine $\left.{ }^{\circledR}\right)$.............56 


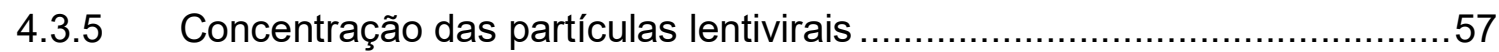

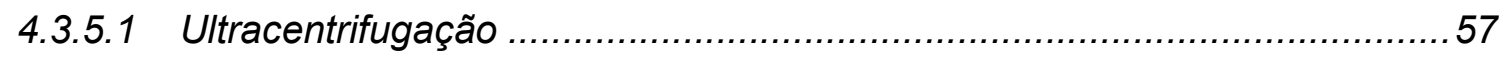

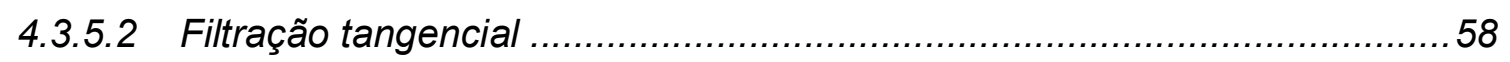

4.3.5.3 Ultrafiltração - Centrifugação sobre membrana...................................60

Ensaio funcional da molécula CAR anti-CD19 .................................61

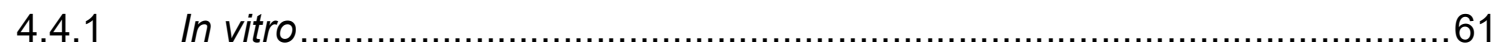

4.4.2 Ensaio de ativação do CAR anti-CD19 ..........................................62

4.5 Ensaio funcional do CAR anti-CD19 em linfócitos T primários............63

4.5.1 Potencial citotóxico in vitro dos linfócitos T CAR .....................................64

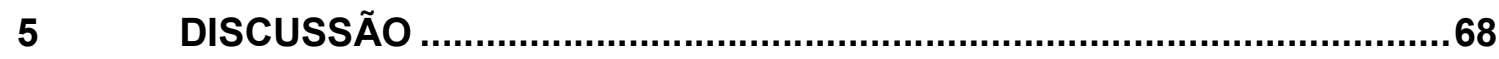

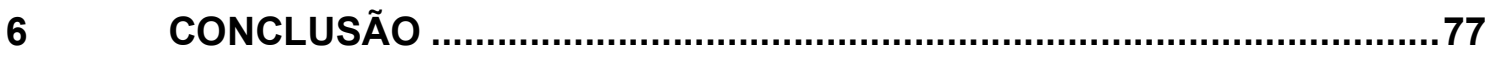

REFERÊNCIAS BIBLIOGRÁFICAS .............................................................. 79

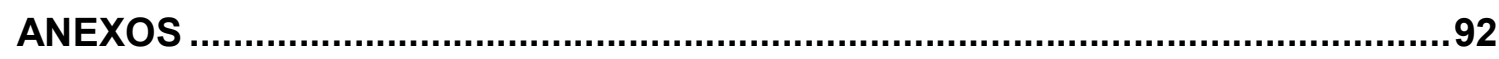


Introdução 


\section{INTRODUÇÃO}

\subsection{Imunoterapia tumoral}

Os tratamentos convencionais para o câncer, como a quimioterapia, apresentam limitações: não são seletivos ou específicos, afetando tanto as células tumorais como as normais; de maneira geral, não eliminam as células-tronco tumorais; muitas vezes são apenas paliativos; e acabam por debilitar o paciente (MROSS; KRATZ, 2011). Nesse contexto, a utilização de moléculas seletivas, capazes de bloquear vias específicas envolvidas na regulação do crescimento tumoral, significou um enorme progresso para o tratamento do câncer (RIBAS; WOLCHOK, 2018).

Sendo assim, a imunoterapia consiste em abordagens tecnológicas que utilizam componentes do sistema imunológico no tratamento de doenças neoplásicas, inflamatórias e imunomediadas (MATHIS; VALLAT; MAGY, 2016). A imunoterapia para o tratamento do câncer é, atualmente, a terapia mais promissora tendo em vista a sua seletividade, o seu potencial curativo e a sua baixa toxicidade. Este tipo de terapia foi descrito como o grande acontecimento científico de 2013 pela revista Science (COUZIN-FRANKEL, 2013) com destaque para as terapias com anticorpos monoclonais anti-CTLA-4 e anti-PD1 (FLEMMING, 2012; HODI et al., 2010) e para os linfócitos $T$ geneticamente modificadas com receptores de antígenos quiméricos, que foram capazes de induzir potente resposta antitumoral (KOCHENDERFER et al., 2010).

A imunoterapia celular é caracterizada pela utilização de células do sistema imune com finalidades terapêuticas (KERSHAW et al., 2014). Os linfócitos T são muitas vezes os imunomediadores finais da regressão do câncer. Com a descoberta de antígenos tumores-associados (ROBBINS; KAWAKAMI, 1996), novas estratégias que utilizam diretamente os linfócitos $\mathrm{T}$ tumor-reativos como uma terapia foram desenvolvidas (JUNE, 2007). Nesta abordagem, denominada de transferência adotiva de células, os linfócitos T citotóxicos são expandidos fora do ambiente potencialmente imunossupressor de um tumor e são reinfundidos em grande número para o paciente com câncer. Historicamente, os linfócitos T antitumorais eram extraídas a partir da remoção cirúrgica de uma metástase do câncer de modo a obter os linfócitos infiltrantes de tumor (TIL). Os TILs demonstram reatividade variável contra diversos tipos de tumores, tais como melanoma (LEE; MARGOLIN, 2012) e tumor 
gastrointestinal (KONO et al., 2002). Apesar da eficácia comprovada, a identificação e isolamento de TILs é de extrema dificuldade o que impede a sua ampla aplicação clínica.

Progressos em tecnologias de engenharia genética tem simplificado a geração de linfócitos $T$ antitumorais, superando muitas das barreiras práticas que têm limitado a ampla utilização de TIL. Ao se introduzir de maneira artificial um receptor de células T (TCR) antígeno-específico em linfócitos T citotóxicos, pode-se aumentar a afinidade destas células por células tumorais (KERSHAW; WESTWOOD; DARCY, 2013). No entanto, esta abordagem ainda depende da apresentação do antígeno alvo pelo complexo principal de histocompatibilidade $(\mathrm{MHC})$ da célula tumoral; limitação que pode ser superada pela introdução de uma estrutura de reconhecimento sintético chamado de receptor quimérico de antígenos (CAR) (ESHHAR et al., 1993; GROSS; WAKS; ESHHAR, 1989). A terapia celular utilizando linfócitos T-CAR é uma abordagem imunoterapêutica emergente para uma variedade de doenças neoplásicas, incluindo linfomas e leucemias. Estes linfócitos T-CAR reconhecem moléculas presentes na superfície das células do tumor independente do sistema MHC, tornando a resposta antitumoral mais efetiva (BRENTJENS et al., 2007; KOCHENDERFER et al., 2009). Essa independência do MHC permite que os linfócitos T-CAR possam ser utilizados para tratar qualquer paciente cujo tumor expresse o antígeno de alvo.

\subsection{Receptor quimérico de antígenos}

A especificidade dos linfócitos $T$ pode ser redirecionada, artificialmente, pela introdução do receptor CAR. Tais receptores possuem um domínio de reconhecimento extracelular, um domínio transmembrana e domínios de sinalização intracelulares (Figura 1).

O domínio extracelular é geralmente formado pelas porções variáveis das cadeias leves e pesadas de uma imunoglobulina (scFv) unidos por um linker flexível. Este domínio é capaz de reconhecer qualquer antígeno a qual possua afinidade. $O$ domínio de reconhecimento do antígeno é ligada ao domínio transmembrana pelo spacer, normalmente derivado da região hinge do IgG1 (RAMOS; DOTTI, 2011). O domínio transmembrana proveniente do CD28 é o que até o momento resulta na maior estabilidade do receptor (ZHANG et al., 2017). O domínio intracelular pode combinar 
sinais do complexo de receptores, como o $\mathrm{CD} 3 \zeta$, e de moléculas co-estimulatórias dos linfócitos T (FINNEY et al., 1998; MAHER et al., 2002).

Figura 1 - Estrutura básica de um receptor quimérico de antígenos (CAR)

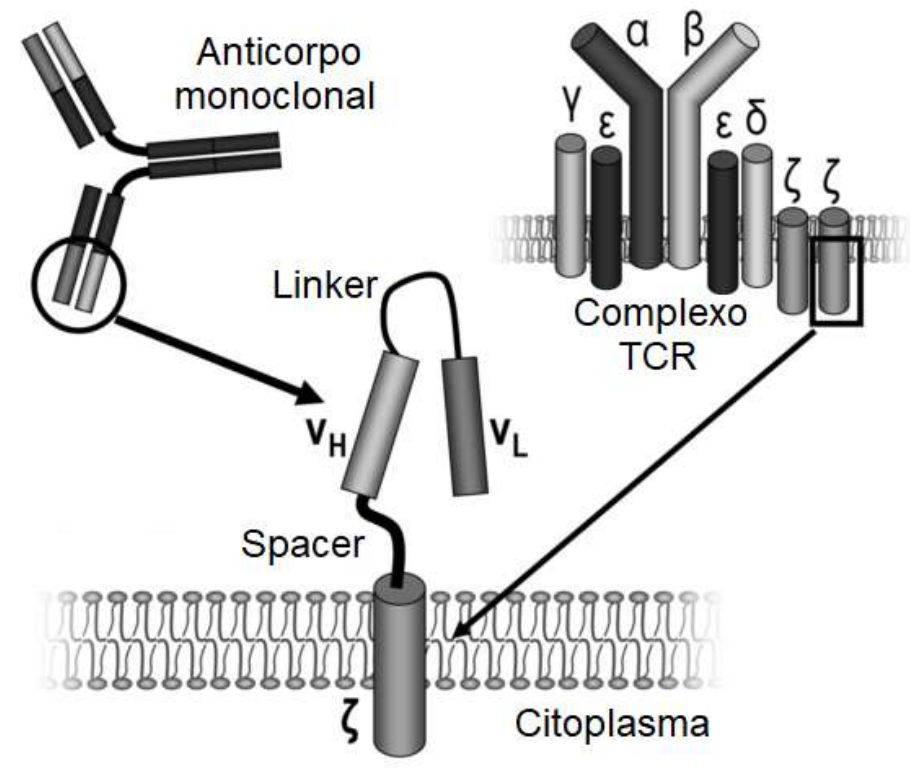

O CAR combina o sítio de reconhecimento de um anticorpo monoclonal na porção extracelular, formado pelos fragmentos variáveis leve $\left(\mathrm{V}_{\mathrm{L}}\right)$ e pesado $\left(\mathrm{V}_{\mathrm{H}}\right)$ unidos por um linker, e o domínio de sinalização $\zeta$ do complexo do receptor de células T (TCR). Adaptado de Ramos e Dotti (2011).

De maneira geral, existem 3 gerações das estruturas do CAR (Figura 2). A primeira consiste apenas de uma estrutura de receptor extracelular baseado em anticorpo e um domínio intracelular que inclui o Motivo de Ativação Baseado em

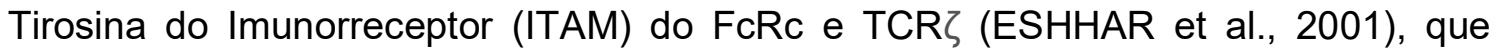
apesar de apresentar atividade in vitro, tem eficácia e persistência baixas in vivo (TILL et al., 2008).

Ao se adicionar domínios de sinalização co-estimulatórios, como CD28, CD137 (4-1BB) ou CD134 (OX40), são obtidos os CARs de segunda geração (KRAUSE et al., 1998; MILONE et al., 2009). Esses CARs apresentam proliferação, citotoxicidade, persistência e eficácia clínica melhoradas (FINNEY et al., 1998; KOWOLIK et al., 2006; MILONE et al., 2009).

A terceira geração compreende CARs que possuem dois ou mais domínios citosólicos de co-estimulação, entre eles CD27, CD28, ICOS, 4-1BB, OX40 (MAUS 
et al., 2014; TILL et al., 2012), o que em tese aumentaria a potência desses linfócitos T contra tumores. Porém, ensaios clínicos usando CARs com CD28 e 4-1BB como co-estimuladores não apresentaram respostas melhores quando comparados com os de segunda geração (MORGAN et al., 2010; TILL et al., 2012). Além disso, o tratamento com CAR de terceira geração levou à morte de um paciente com câncer colorretal, devido a uma exacerbada toxicidade provocada pelos linfócito-T CAR (MORGAN et al., 2010).

Figura 2 - Evolução dos receptores quiméricos de antígeno

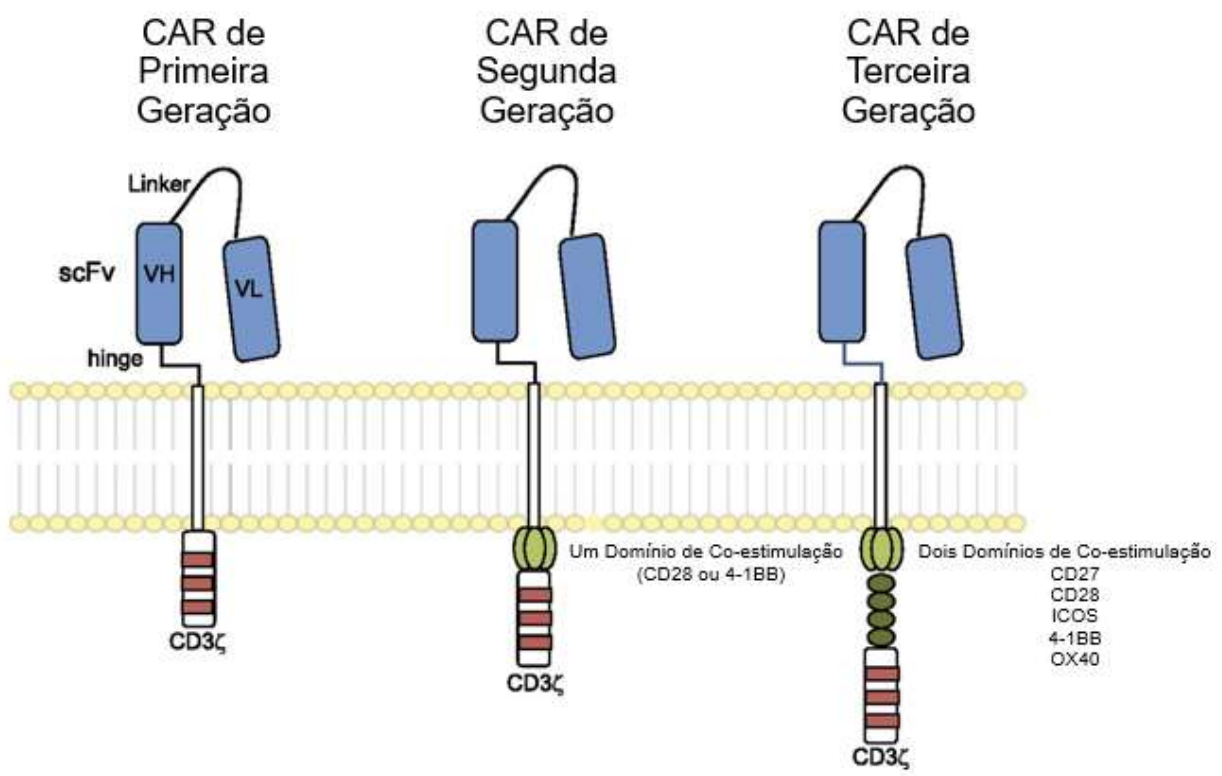

Primeira geração contém apenas o $\mathrm{CD} 3 \zeta$ na porção intracelular. Moléculas co-estimulatórias, como CD28 ou 4-1BB foram inseridas na região de transdução do sinal na segunda geração. Uma molécula co-estimulatória adicional foi incorporada à região de transdução do sinal na terceira geração (CD27, CD28, ICOS, 4-1BB ou OX40). Adaptado de Maus et al. (2014).

\subsubsection{Antígeno alvo}

Para se escolher um antígeno alvo é necessário levar em conta os benefícios e os riscos. O antígeno ideal é aquele que deve estar expresso apenas nas células cancerosas, não presente em células do tecido normal, ou quando estiver, estas células não devem ser indispensáveis (MAUDE; BARRETT, 2015). Os primeiros trabalhos com CARs focaram suas atenções no antígeno CD19, devido ao seu envolvimento no desenvolvimento dos linfócitos B. Esta molécula de superfície está presente apenas em células dendríticas foliculares e linfócitos B (SCHRIEVER et al., 
1989; TEDDER, 2009). A expressão de CD19 é perdida durante a diferenciação terminal dos linfócitos B em plasmócitos (Figura 3). Entre todas os demais antígenos presentes na superfície do linfócito B, CD19 é altamente expresso em praticamente todas as leucemias e linfomas de linhagem $B$, incluindo leucemia linfoide crônica e aguda e diversos linfomas não-Hodgkin (SCHEUERMANN; RACILA, 1995), o que o torna um ótimo candidato para desenvolvimento de CARs contra estes tumores (BOULASSEL; GALAL, 2012). Estes motivos, além do fato desta molécula não ser expressa nas células-tronco hematopoiéticas, tornaram o CD19 o alvo ideal no desenvolvimento de CAR e o alvo para ensaios clínicos mais bem sucedido (BARRETT et al., 2014).

Figura 3 - Expressão de marcadores de superfície em linfócitos B e neoplasias associadas

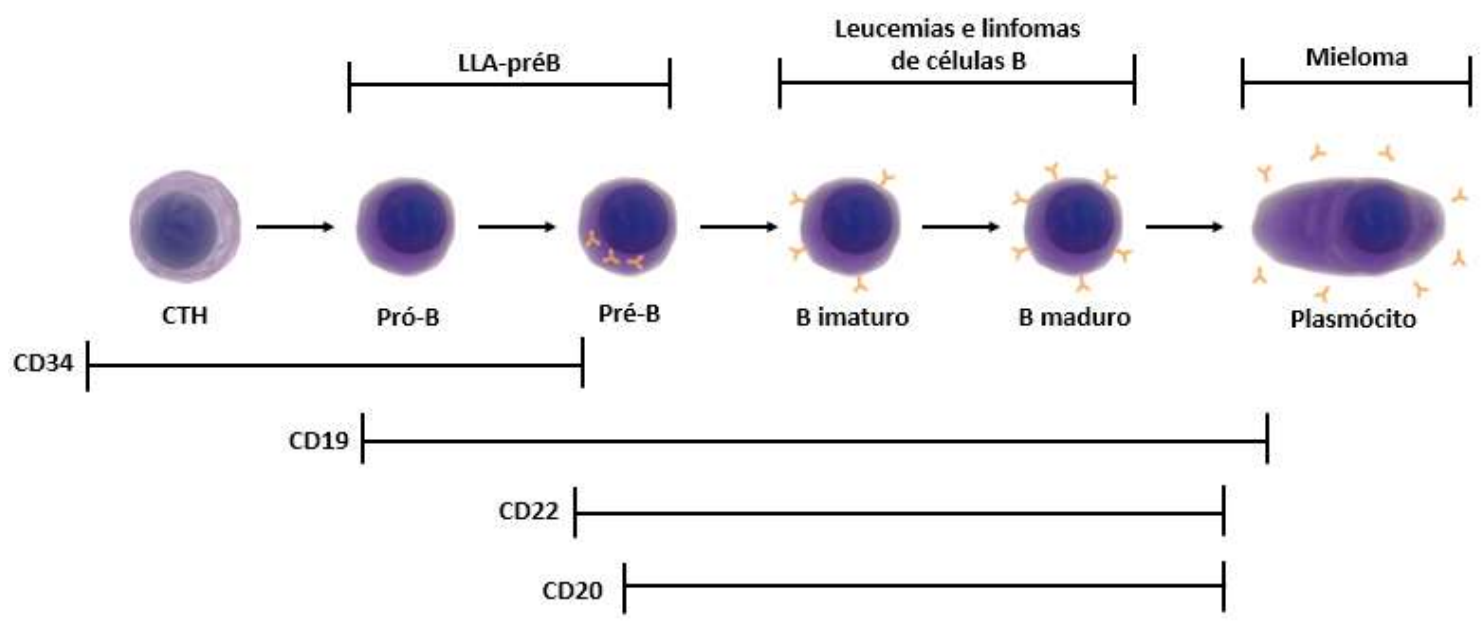

Células-tronco hematopoiéticas (CTH) são positivas para CD34, mas negativas para marcadores de linhagem B. Células pró-B se comprometeram com a linhagem B e passam a expressar CD19 durante todos os estágios de maturação, passando a expressar também CD20 e CD22. Plasmócitos terminalmente diferenciados perdem a expressão destes marcadores. Adaptado de Scheuermann e Racila (1995).

Pacientes de leucemia linfoide aguda (LLA) que passam por transplante alogênico de células-tronco hematopoiéticas ou infusão de linfócitos correm o risco de sofrerem da doença do enxerto contra o hospedeiro (DEcH). A DEcH ocorre quando os linfócitos transplantados reconhecem os tecidos do hospedeiro como não-próprios, atacando-os (GOKER; HAZNEDAROGLU; CHAO, 2001). Ao se utilizar linfócitos TCAR autólogos ao invés do transplante alogênico de células-tronco hematopoiéticas, evita-se a DEcH em pacientes de LLA (MAUDE et al., 2015). 


\subsubsection{Ensaios clínicos com CAR}

Diversos ensaios clínicos estão sendo realizados a partir do desenvolvimento de terapias com linfócitos T-CAR, tanto para tumores hematológicos quanto sólidos (Tabela 1). Terapias com linfócitos T-CAR anti-CD19 são, atualmente, as mais testadas contra neoplasias de linfócitos B. Respostas clínicas surpreendentes e atividade robusta foram demonstradas em ensaios clínicos, induzindo remissão em crianças e jovens adultos com leucemias linfoides (BRENTJENS et al., 2011; DAVILA et al., 2014; KOCHENDERFER et al., 2013; LEE et al., 2015; MAUDE et al., 2014). Ensaios clínicos em leucemia linfoide crônica (LLC) mostram que linfócitos T-CAR anti-CD19, contendo o domínio de co-estimulação 4-1BB conseguem proliferar com sucesso in vivo, eliminando a doença e apresentando atividade funcional por mais de 3 anos (KALOS et al., 2013). Estudos de 3 diferentes grupos relatam taxas de remissão completa de $70 \%$ a $90 \%$ dos pacientes com LLA tratados com linfócitos T CAR anti-CD19 (DAVILA et al., 2014; LEE et al., 2015; MAUDE et al., 2014). 
Tabela 1 - Terapias com linfócitos T CAR em desenvolvimento

\begin{tabular}{|c|c|}
\hline Tumores hematológicos & Alvo \\
\hline \multicolumn{2}{|l|}{ Hematológicos } \\
\hline Neoplasias de células B (ensaios amplos) & $\begin{array}{l}\text { CD19, CD22, CD30, CD19/CD20 } \\
\text { bi-específico, kappa } 28\end{array}$ \\
\hline Neoplasias de células T (ensaios amplos) & CD5, CD30 \\
\hline Leucemia linfoide aguda & $\begin{array}{l}\text { CD19, CD22, CD19/22 bi- } \\
\text { específico }\end{array}$ \\
\hline Leucemia mieloide aguda & CD33, CD123, ligante NKG2D \\
\hline Leucemia linfoide crônica & CD19 \\
\hline Linfoma difuso de células B grandes & CD19, CD19/22 bi-específico \\
\hline Linfoma de Hodgkin & RNA CD19, CD30 \\
\hline Linfoma de células do manto & CD19 \\
\hline Mieloma múltiplo & CD19, BCMA, ligante MKG2D \\
\hline Síndrome mielodisplásica & Ligante MKG2D \\
\hline Linfoma não-Hodgkin & CD19, CD20, CD30 \\
\hline Neoplasias ROR1 ${ }^{+}$ & ROR1 \\
\hline Linfoma linfocítico de pequenas células & CD19 \\
\hline \multicolumn{2}{|l|}{ Sólidos } \\
\hline Tumores sólidos (ensaios amplos) & $\begin{array}{l}\text { CD70, GD2, glipicano-3, } \\
\text { mesotelina, ligante NKG2D }\end{array}$ \\
\hline Adenocarcinoma & CEA \\
\hline Mama & RNA cMet, mesotelina \\
\hline Glioblastoma & EGFR, HER2, IL-13(R) \\
\hline Carcinoma hepatocelular & Glipicano-3 \\
\hline Melanoma & VEGF(R) \\
\hline Mesotelioma & Mesotelina \\
\hline Neuroblastoma & GD2, CD171 \\
\hline Pâncreas & CD19, PSCA, SS1 \\
\hline Próstata & PSMA \\
\hline Carcinoma renal & VEGF(R) \\
\hline Neoplasias ROR1 ${ }^{+}$ & ROR1 \\
\hline Sarcoma & GD2, HER2 \\
\hline
\end{tabular}

Adaptado de Littman e Hexner (2017).

Em um recente ensaio com pacientes com LLC que haviam passado sem sucesso por tratamento com ibrutinib, medicamento que bloqueia sinais que levam os linfócitos B malignos a crescerem e se dividirem, a resposta completa ou parcial foi de 
71\% após 4 semanas da infusão dos linfócitos T-CAR (TURTLE et al., 2017). A persistência dos linfócitos T-CAR parece ser superior em pacientes com LLC, apesar das taxas de remissão completa serem superiores no tratamento de LLA (BROWN; PORTER; O'BRIEN, 2014). Em um caso relatado, um paciente com mieloma múltiplo passou por transplante autólogo e tratamento com linfócitos T-CAR anti-CD19, resultando em resposta completa sem evidência de progressão do tumor, 12 meses após o tratamento (GARFALL et al., 2015). Todos os pacientes que respondem ao tratamento desenvolvem aplasia de linfócitos B e hipogamaglobulinemia. Apesar de serem considerados como resultado de toxicidade on-target, também são uma medida de persistência funcional (MAUDE et al., 2015).

\subsection{Modificação genética}

Diversas plataformas de transferência gênica têm se desenvolvido e estão disponíveis para introduzir o transgene do CAR em linfócitos T primários. A inserção do transgene pode ser realizada por transdução mediada por vírus (BRENTJENS et al., 2013; KALOS et al., 2011; KOCHENDERFER et al., 2013, 2015), transfecção de RNA mensageiro (BEATTY et al., 2014), transposons Sleeping Beauty (HULS et al., 2013; SINGH et al., 2013), transposons piggyBac (MORITA et al., 2018), ou transferência não viral de plasmídeos de DNA (JENSEN et al., 2000). A maioria dos estudos atuais utilizam de vetores retrovirais, como vetores lentivirais e $\gamma$-retrovirais (SUERTH; SCHAMBACH; BAUM, 2012). A escolha desses vetores está diretamente associada à sua alta eficiência de transferência gênica, e persistência da expressão do transgene durante a expansão in vivo das células transduzidas.

Assim que o vetor viral entra no linfócito $T$, seu material genético é introduzido. O material genético dos retrovírus é o RNA, que passa por transcrição reversa em DNA dentro da célula hospedeira. Esse material genético irá codificar a expressão do receptor CAR. O DNA é então integrado no genoma celular de modo permanente. Após transcrição e tradução do gene CAR, o receptor é expresso na superfície do linfócito T modificado (LEVINE et al., 2017).

Recentemente, os lentivírus têm substituído o uso de y-retrovírus por apresentarem características que tornam seu uso mais seguro, como tendência à menor genotoxicidade e à não integração em genes regulatórios (MCGARRITY et al., 2013; MONTINI et al., 2006, 2009). Enquanto os retrovírus tendem a se integrar em 
regiões promotoras, os lentivírus se inserem principalmente na cromatina aberta (NESCHADIM et al., 2007). Outras vantagens dos lentivírus sobre os Y-retrovírus são sua habilidade de infectar células que não estão em divisão (LEWIS; EMERMAN, 1994), menor propensão ao silenciamento, habilidade de transferir grandes transgenes (PFEIFER et al., 2002).

\subsubsection{Vetores lentivirais}

Os vetores lentivirais são derivados principalmente de lentivírus de primatas como o vírus da imunodeficiência humana (HIV-1 e HIV-2) ou símia (SIV), além de lentivírus de não-primatas como o vírus da anemia infecciosa equina (EIAV), o vírus da imunodeficiência felina (FIV) e o vírus da artrite encefalite caprina (CAEV) (SCHWEIZER; MERTEN, 2010), sendo que o mais utilizado nas pesquisas são os vetores derivados do HIV-1.

O genoma do HIV-1 (Tabela 2) é composto por 9 genes e é basicamente organizado pelos genes gag, pol e env. O gene gag é responsável pela formação das

partículas virais e pelo empacotamento do RNA genômico viral. O gene env é responsável pela formação do envelope viral, que irá se ligar e permitir a entrada na célula hospedeira. O gene pol codifica a transcriptase reversa, que transcreve o RNA em DNA, a integrase que catalisa a integração do DNA no genoma celular, e a protease envolvida na maturação do vírion (ESCORS; BRECKPOT, 2010). 
Tabela 2 - Genes do HIV-1 e suas funções

\begin{tabular}{|c|c|}
\hline Genes & Funcões \\
\hline \multicolumn{2}{|c|}{ Genes regulatórios } \\
\hline tat & Transativação da expressão gênica \\
\hline rev & $\begin{array}{l}\text { Exportação nuclear de mRNAs tardios; promoção da } \\
\text { ligação a RNAs que contêm RRE }\end{array}$ \\
\hline \multicolumn{2}{|c|}{ Genes acessórios } \\
\hline vif & Melhoramento da transmissão viral \\
\hline$v p r$ & $\begin{array}{l}\text { Transporte nuclear do DNA pró-viral; indução de parada } \\
\text { em } \mathrm{G}_{2} \text { em células em divisão }\end{array}$ \\
\hline vpu & Degradação de CD4; maturação e liberação viral \\
\hline nef & $\begin{array}{l}\text { Supressão de CD4 e MHC-I; melhoramento da replicação } \\
\text { viral }\end{array}$ \\
\hline \multicolumn{2}{|c|}{ Genes estruturais } \\
\hline gag & $\begin{array}{l}\text { Formação das partículas virais; empacotamento do RNA } \\
\text { genômico viral }\end{array}$ \\
\hline pol & Transcrição reversa, integração e maturação do vírion \\
\hline env & Ligação e entrada na célula hospedeira \\
\hline
\end{tabular}

Adaptado de Ramezani e Hawley (2002).

Além disso, o genoma lentiviral contém sequências de atuação em cis, como as duas repetições terminais longas (LTR), responsáveis pela regulação da transcrição dos genes virais e pela integração do material genético viral no genoma da célula hospedeira. O genoma viral contém ainda um sinal de empacotamento $\Psi$, responsável pelo empacotamento do RNA nos vírions recém-formados (ESCORS; BRECKPOT, 2010; WATANABE; TEMIN, 1982).

Existem atualmente três gerações de vetores lentivirais derivados do HIV-1 (Figura 4). A primeira geração foi obtida ao se separar os genes do HIV-1 em 3 cassetes distintos: expressão, capsídeo e envelope. Além disso, deletou-se os genes env, vpu e o sinal de empacotamento $\Psi$ do cassete do capsídeo. O LTR 5' do cassete do capsídeo também foi substituído pelo promotor do citomegalovírus (CMV) e o LTR 3' foi substituído por uma cauda poli(A). O envelope original do lentivírus foi substituído pelo envelope do vírus da estomatite vesicular (VSV-G). O cassete que codifica este envelope é composto promotor CMV e do gene para a glicoproteína VSV-G. Por fim, o cassete de expressão contém o transgene com um promotor interno, como o CMV, e os LTRs e sequências que atuam em cis do HIV-1 intactas. A utilização dessa 
conformação diminui as chances de que vírus replicantes sejam produzidos pelas células hospedeiras (DUBRIDGE et al., 1987).

Figura 4 - Representação esquemática de vetores derivados do HIV-1

A derivado do HIV-1

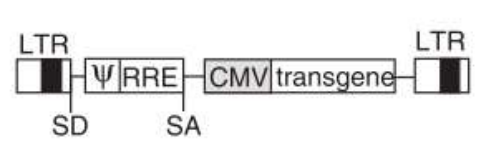

SA

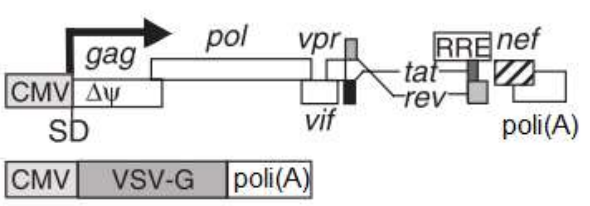

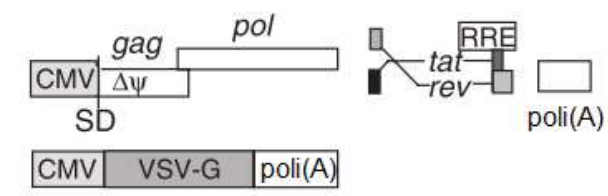

B derivado do HIV-1
Vetor de segunda geração

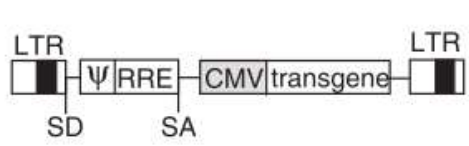

LTR \begin{tabular}{|l|l|l|}
\hline CMV & VSV-G & poli(A) \\
\hline
\end{tabular}

C

Vetor de terceira geração derivado do HIV-1
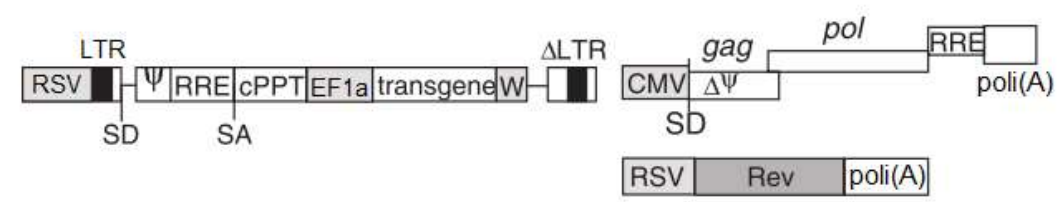

\begin{tabular}{|l|l|l|}
\hline CMV & VSV-G & poli(A) \\
\hline
\end{tabular}

(A) Primeira geração expressando todas as proteínas do HIV-1 exceto Vpu e Env. As partículas são pseudotipadas com VSV-G expresso em um plasmídeo separado. (B) Vetor de segunda geração, no qual todos os genes acessórios foram removidos. (C) Vetor de terceira geração independente de Tat. Os dois cassetes do capsídeo codificam apenas as proteínas Gag, Pol e Rev. O vetor representado possui contém o CPPT para transferência nuclear eficiente e utiliza o promotor EF-1a (EF1a) e o WPRE (W). O sinal de empacotamento está representado por $\Psi$ e $\Delta$ representa deleções. Adaptado de Ramezani e Hawley (2002).

A segunda geração foi criada ao se observar que nenhum dos genes acessórios do HIV-1 eram necessários nem para replicação do HIV-1 nem para geração de vetores lentivirais com VSV-G (MILLER; SARVER, 1997; ZUFFEREY et al., 1997). Esta remoção também traz mais segurança além de proporcionar que o vetor viral possa carregar um transgene maior.

Para a criação da terceira geração, diversas modificações foram feitas para evitar a potencial geração de vírus competentes em replicação: deleção na região LTR 3' do cassete de expressão; substituição da região U3 do LTR 5' do cassete de expressão pelos promotores CMV e do vírus do Sarcoma de Rous (RSV); e deleção do gene tat do cassete do capsídeo sem que a eficiência de transdução fosse afetada. 
O genes gag-pol e rev podem ser expressos em dois cassetes separados, refinando o sistema de empacotamento (DULL et al., 1998; PICANÇO-CASTRO et al., 2008; RAMEZANI; HAWLEY, 2002). A deleção da região enhancer e do promotor na região U3 do LTR 3' levou à criação dos vetores autoinativantes (SIN) (MIYOSHI et al., 1998). Após a transcrição reversa, esta deleção é transferida para a região U3 do LTR 5' do DNA pró-viral. Isto leva à inativação transcricional do LTR e impedindo a expressão do RNA do vetor, minimizando a possibilidade de se gerar vírus competentes em replicação. Os vetores SIN necessitam de um promotor interno para que o transgene seja expresso (PICANÇO-CASTRO et al., 2008; ZUFFEREY et al., 1998). Um promotor interno amplamente utilizado é o EF-1a, que promove uma elevada expressão do transgene (GOPALKRISHNAN et al., 1999; KIM et al., 1990, 2007). A adição da sequência cPPT (central polypurine tract) facilita a entrada do DNA viral no núcleo, aumentando a eficiência de transdução tanto de células em divisão quanto estacionárias (ZENNOU et al., 2000). O elemento regulatório WPRE do vírus da hepatite pode ser adicionado na região 3' do transgene, aumentando a estabilidade do transcrito e, por consequência, sua expressão (ZUFFEREY et al., 1999).

O envelope original do HIV pode ser substituído por diversos envelopes glicoproteicos, mas o mais amplamente utilizado é o VSV-G devida à sua capacidade de infectar diversos tipos celulares (BURNS et al., 1993). O envelope VSV-G também irá tornar as partículas virais mais resistentes ao congelamento e descongelamento, e a métodos de concentração e purificação (KUTNER; ZHANG; REISER, 2009; TRANSFIGURACION et al., 2003)

\subsubsection{Produção de vetores lentivirais}

A produção de vetores virais pode ser realizada de diferentes maneiras, mas as mais predominantes, segundo Merten et al. (2004, 2011), envolvem o uso de células de mamíferos em sistemas de células aderentes ou em suspensão.

O método mais utilizado para geração de vetores lentivirais é a transfecção transiente de células HEK293 com os vetores contendo os cassetes de expressão, o capsídeo (um ou dois plasmídeos) e o envelope (VAN DER LOO; WRIGHT, 2016). Estas células, derivadas de rim embrionário humano, são amplamente utilizadas por serem altamente transfectáveis (PICANÇO-CASTRO et al., 2008). Criado por DuBridge et al. (1987) a partir da transfecção estável de células HEK293T, a linhagem 
celular HEK293T possui uma versão termo-sensível do grande antígeno $\mathrm{T}$ do vírus vacuolante símio 40 (SV40). Devido à presença deste antígeno T, plasmídeos transfectados que contenham a origem de replicação do SV40 serão replicados, resultando no aumento de vetores lentivirais produzidos pelas células HEK293T (GAMA-NORTON et al., 2011; MERTEN et al., 2011). O antígeno T também aumenta a transferência dos vetores de expressão para o interior do núcleo celular (GRAESSMANN et al., 1989).

As células HEK293T são aderentes e seu uso está normalmente associado à produção de partículas virais em pequena escala, seja em placas de Petri, frascos $\mathrm{T}$, ou garrafas multi-andares. O aumento da produção para satisfazer a quantidade necessária para utilização em ensaios clínicos se faz geralmente pelo escalonamento e aumento da área de superfície para o crescimento celular (MERTEN; HEBBEN; BOVOLENTA, 2016).

Diversos compostos são usados como reagentes de transfecção, sendo o fosfato de cálcio o mais amplamente usado por oferecer uma boa relação custo benefício (PICANÇO-CASTRO et al., 2008). No entanto, a transfecção com fosfato de cálcio é altamente sensível a variações no $\mathrm{pH}$, resultando em baixa reprodutibilidade (KURODA et al., 2009). Outros métodos menos laboriosos existem, como o uso do polímero Polietilenoimina (PEI) (BOUSSIF et al., 1995; DONG et al., 2007; LONGO et al., 2013) e os lipídeos catiônicos (FELGNER et al., 1987; MA et al., 2007). O PEl é um polímero catiônico que forma um complexo com o DNA, e neutraliza as cargas negativas presentes nos ácidos nucleicos (BOUSSIF et al., 1995). Esse complexo sofre então endocitose e o DNA é liberado dentro do citoplasma celular. De forma semelhante, os lipídios catiônicos formam lipossomos com o DNA e se fundem à membrana celular, permitindo que o DNA seja introduzido na célula (DALBY, 2004).

A variabilidade na eficiência de transdução e a falta de escalonabilidade e reprodutibilidade são pontos que requerem controle rigoroso, quando se refere à produção de vetores lentivirais para uso clínico (VAN DER LOO; WRIGHT, 2016). A produção com lipídeos catiônicos não sofre com variabilidade e pode ser realizada em diversas células humanas (MA et al., 2007). No entanto, estes lipídios catiônicos apresentam um custo elevado quando comparados com o fosfato de cálcio e o PEI, o 
que pode inviabilizar a sua utilização para produções em larga escala (KAROLEWSKI et al., 2003; SEGURA et al., 2010).

A produção de vetores virais em células aderentes tem limitações quanto a escalonabilidade, apesar de ser considerado o método padrão, pois demanda uma grande superfície na qual a célula irá aderir (SCHWEIZER; MERTEN, 2010). Desta forma, o método mais conveniente para produções industriais é a utilização do cultivo celular em biorreatores, com células em suspensão (ANSORGE et al., 2009; BALDI et al., 2008).

A concentração dos estoques de partículas virais, para aumento do título viral e remoção de impurezas, é normalmente feita por ultracentrifugação de 20.000 a $90.000 \times g$ (BURNS et al., 1993; KOWOLIK; YEE, 2002; KUTNER; ZHANG; REISER, 2009; YACOUB et al., 2007). No entanto, a ultracentrifugação pode levar à perda de vírus viáveis devido ao dano sofrido pelos vírions por causa das tensões de cisalhamento. Partículas virais com o envelope VSV-G são mais resistentes ao processo de concentração (BURNS et al., 1993). A ressuspensão dos pellets de vírus pode gerar variabilidade ao processo de concentração por ultracentrifugação, além disso este método é limitado pela capacidade de volume dos rotores (ZHANG et al., 2001). Existe também a possibilidade de se co-concentrar debris celulares e impurezas de alto peso molecular (TRANSFIGURACION et al., 2003).

Outras técnicas, como a cromatografia (KUTNER; ZHANG; REISER, 2009; SEGURA et al., 2010), a ultrafiltração sobre membrana (BANDEIRA et al., 2012; COLEMAN et al., 2003; REISER, 2000; SENA-ESTEVES et al., 2004), e a filtração tangencial (COOPER et al., 2011; GERAERTS et al., 2005) também são amplamente empregadas. Tanto a ultrafiltração quanto a filtração tangencial utilizam membranas com corte molecular que variam de 100 a 500 kDa (BANDEIRA et al., 2012; MERTEN et al., 2011). Enquanto a ultrafiltração é limitada pelo volume das unidades filtradoras, a filtração tangencial é uma tecnologia altamente escalonável podendo ser empregada em produções em larga escala (SCHWEIZER; MERTEN, 2010).

A Organização Mundial da Saúde estimou a existência de quase 33 milhões de pessoas vivendo com câncer em todo o globo no ano de 2012. No mesmo ano, foram diagnosticados 14,1 milhões de casos novos e morreram 8,2 milhões de pessoas em decorrência da doença, totalizando $13 \%$ das mortes por ano no mundo (FERLAY et 
al., 2015). O Instituto Nacional de Câncer José Alencar Gomes da Silva (2017) projetou para 2018 a ocorrência de 635 mil casos novos de câncer no Brasil, o que representa um incremento de 10\% na incidência projetada para 2014. Destes, 21 mil casos serão de leucemias e linfomas não-Hodgkin.

Linfócitos $T$ modificados para expressarem receptores quiméricos têm se mostrado eficazes como terapia celular no tratamento de leucemias linfoides, sendo que os vetores lentivirais são o método de modificação genética mais utilizados nos ensaios clínicos. Diversas metodologias podem ser empregadas na produção destes vetores e precisam ser adaptadas e otimizadas para cada vetor produzido que carregue um transgene diferente. Dentro deste contexto, o presente estudo teve como proposta a avaliação e otimização da metodologia para produção de vetores lentivirais contendo o transgene CAR anti-CD19 para modificação de linfócitos T. Nossa hipótese é de que a transfecção transiente de células aderentes com lipídeo catiônico e adição de butirato de sódio poderia gerar grandes quantidades de vetores lentivirais anti-CD19. 
Objetivos 


\section{OBJETIVOS}

\subsection{Objetivo geral}

$\checkmark$ Estabelecimento de condições otimizadas para produção de vetores lentivirais destinados à expressão de receptores quiméricos de antígeno anti-CD19.

\subsection{Objetivos específicos}

$\checkmark$ Produção dos DNAs plasmidiais utilizados na produção lentiviral;

$\checkmark$ Avaliação de diferentes condições de transfecção;

$\checkmark$ Avaliação de diferentes tempos de coleta do sobrenadante celular contendo as partículas lentivirais;

$\checkmark$ Concentração das partículas lentivirais;

$\checkmark$ Avaliação da funcionalidade e especificidade do vetor CAR anti-CD19 através de ensaios de potencial citotóxico in vitro dos linfócitos T-CAR 
Material e métodos 


\section{MATERIAL E MÉTODOS}

\subsection{Fluxograma}

A Figura 5 apresenta o fluxograma das etapas do projeto.

Figura 5 - Fluxograma ilustrativo das etapas de desenvolvimento do projeto

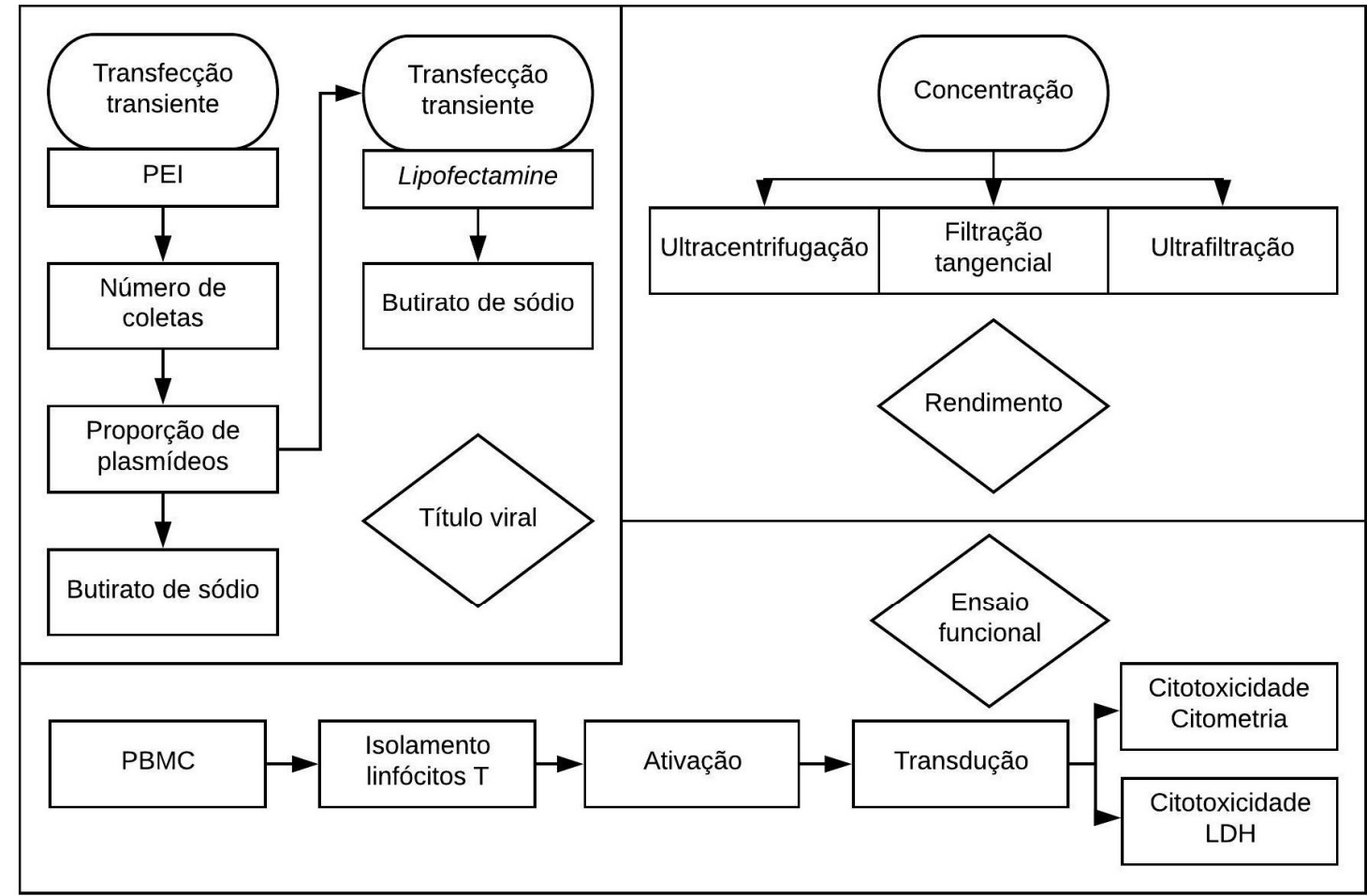

\subsection{Aspectos éticos}

A produção do vetor lentiviral CAR anti-CD19 foi aprovada pelo Comitê de Biossegurança (Processo CIBio/CTNBio número 297/2015.010-02). Os protocolos de coleta de sangue proveniente do filtro de leucorredução proveniente da doação de plaquetas por indivíduos saudáveis foram aprovados pelo Comitê de Ética em Pesquisa do Hospital das Clínicas da Faculdade de Medicina de Ribeirão Preto (Processo CEP-HCFMRP número 1.996.240), e pela Comissão Nacional de Ética em Pesquisa (Processo CONEP número 2.183.633). Os documentos de aprovação estão disponíveis em anexo. 


\subsection{Vetores plasmidiais utilizados}

- pCAR19 - cassete de expressão: contém o gene para o receptor quimérico de antígenos (CAR) anti-CD19 e com 4-1BB como domínio de co-estimulação;

- LentiArt ${ }^{\mathrm{TM}}$ pHelp1 - cassete do capsídeo: contém os genes virais gag, pol e $R R E$; responsável pelo empacotamento do vírus;

- LentiArt ${ }^{\mathrm{TM}}$ pHelp2 - cassete do envelope: contém o gene para o envoltório viral VSV-G;

- LentiArt ${ }^{\mathrm{TM}}$ pHelp3 - cassete do capsídeo: contém o gene viral rev; responsável pelo empacotamento do vírus.

Todos os plasmídeos (Figura 6) foram adquiridos da Creative Biolabs.

Figura 6 - Esquema dos vetores utilizados na produção viral através da co-transfecção transiente

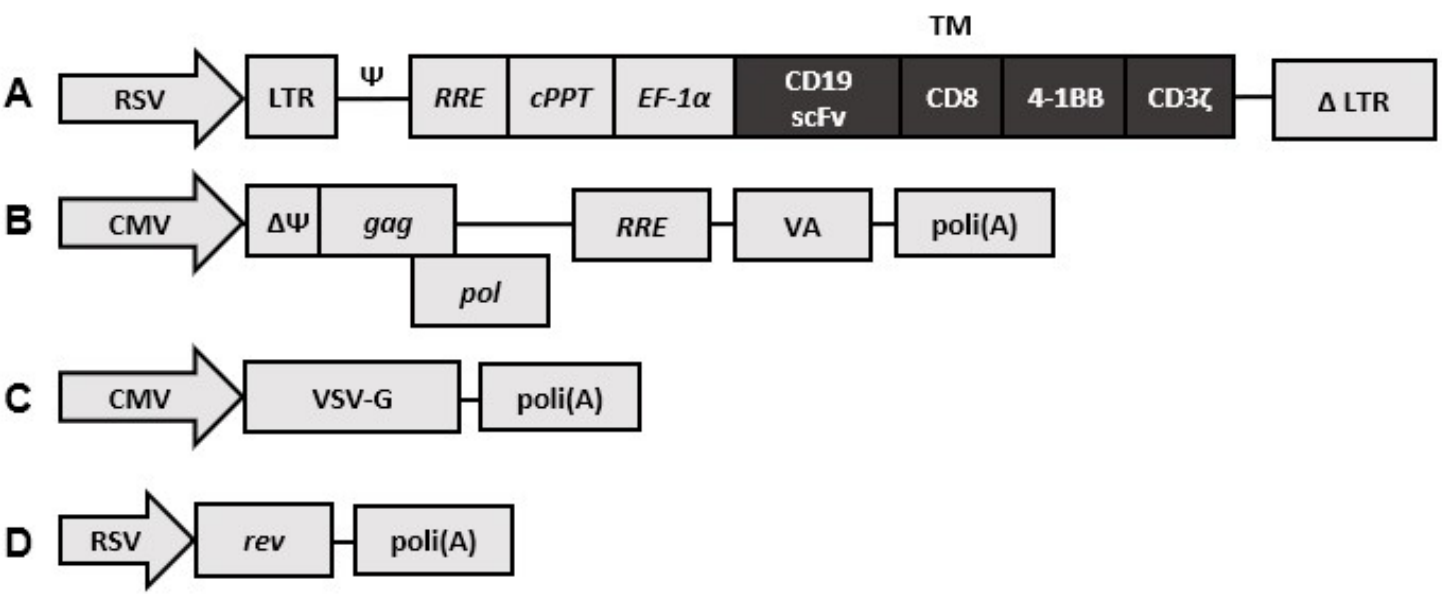

Vetores de terceira geração derivados do HIV-1. (A) Cassete de expressão (pCAR) contendo o promotor RSV, o cPPT e o promotor interno EF-1a. O transgene CAR (em cinza escuro) contém o fragmento variável de cadeia única (scFv) anti-CD19, porção transmembrana (TM) do CD8, domínio de co-estimulação 4-1BB e cadeia CD3ろ do receptor de células T. (B) Cassete do capsídeo (pHelp1) contendo o promotor CMV e os genes necessários para o empacotamento. (C) Cassete do envelope (pHelp2) para pseudotipagem com VSV-G. (D) Cassete do capsídeo (pHelp3). O sinal de empacotamento está representado por $\Psi$ e $\Delta$ representa deleções. Adaptado de Creative Biolabs.

\subsection{Linhagem de bactéria utilizada}

Em todas as transformações foram utilizadas Escherichia coli quimicamente competentes (HANAHAN, 1983). Vetores lentivirais transformados em linhagens RecA podem sofrer recombinação no seu material genético e para evitar possíveis 
recombinações, neste trabalho, foi utilizada a linhagem RecA negativa Stb/3 ${ }^{\mathrm{TM}}$ (Invitrogen) que possui o seguinte genótipo: $\mathrm{F}^{-} m c r \mathrm{~B}$ mrhsdS20( $\left.\mathrm{r}_{\mathrm{B}^{-}}, \mathrm{m}_{\mathrm{B}^{-}}\right)$recA13 supE44 ara-14 galK2 lacY1 proA2 rpsL20(StrR) xyl-5 $\lambda$-leumtl-1.

\subsection{Meios para cultura de bactérias}

a) LB líquido: $5 \mathrm{~g}$ de extrato de levedura, $10 \mathrm{~g}$ de $\mathrm{NaCl}$ e $10 \mathrm{~g}$ de triptona foram dissolvidos em $1 \mathrm{~L}$ de água. $\mathrm{O}$ pH da solução foi ajustado entre 7,3 e 7,4 e o meio foi autoclavado.

b) LB ágar: 2,5 g de extrato de levedura, $5 \mathrm{~g}$ de $\mathrm{NaCl}, 5 \mathrm{~g}$ de triptona e 7,5 $\mathrm{g}$ de ágar-ágar foram dissolvidos em $500 \mathrm{~mL}$ de água. $\mathrm{O}$ pH da solução foi ajustado entre 7,3 e 7,4 e o meio foi autoclavado.

\subsection{Transformação bacteriana}

Em um tubo, $6 \mu \mathrm{L}$ de solução contendo o cassete (300 ng/ $\mathrm{hL}$ ) foram adicionados a $150 \mu \mathrm{L}$ de bactérias competentes. A transformação foi realizada por choque térmico, no qual o tubo contendo DNA e bactérias foi incubado por $30 \mathrm{~min}$ em gelo, por 50 segundos a $42^{\circ} \mathrm{C}$ e 2 min em gelo. Adicionou-se $250 \mu \mathrm{L}$ de meio SOC (20 $\mathrm{mM}$ glicose e meio $S O B$ contendo $1 \mathrm{mM} \mathrm{MgCl}_{2}, 1 \mathrm{mM} \mathrm{MgSO}_{4}$ ) e as bactérias foram incubadas por $1 \mathrm{~h}$ a $37^{\circ} \mathrm{C}$.

\subsection{Max-preparação de plasmídeos}

Este método foi utilizado para obter DNA plasmidial em larga escala (>100 $\mu \mathrm{g})$ e de alta qualidade (sem endotoxinas) para ser utilizado nas transfecções para produção de partículas lentivirais.

A mistura contendo as bactérias transformadas foi inoculada com alça em placa de Petri contendo meio LB-ágar e ampicilina (100 mg/mL). A ampicilina seleciona as bactérias contendo o vetor plasmidial. Após incubação overnight a $37^{\circ} \mathrm{C}$, uma colônia isolada foi inoculada em $5 \mathrm{~mL}$ de meio LB líquido com $100 \mathrm{mg} / \mathrm{mL}$ de ampicilina e préincubada em shaker a $250 \mathrm{rpm}$ a $37^{\circ} \mathrm{C}$ overnight. Após a pré-incubação, $250 \mu \mathrm{L}$ do meio com bactérias foi inoculado em erlenmeyer contendo $250 \mathrm{~mL}$ de LB líquido e ampicilina $(100 \mathrm{mg} / \mathrm{mL})$. Os frascos foram incubados em shaker a $250 \mathrm{rpm}$ a $37^{\circ} \mathrm{C}$ overnight. Além disso, essas bactérias foram estocadas em solução de glicerol $70 \%$ a $-80^{\circ} \mathrm{C}$. Após a incubação as bactérias cultivadas nos erlenmeyers foram peletizadas 
e congeladas para posterior extração do DNA plasmidial. A extração do DNA plasmidial foi feita utilizando-se o HiSpeed Plasmid Maxi Kit (QIAGEN), seguindo o protocolo do fabricante.

\subsection{Quantificação dos ácidos nucleicos}

A quantificação das amostras de DNA foi realizada por espectrofotometria (NanoVue Plus ${ }^{\mathrm{TM}}$, GE Healthcare). A pureza das amostras foi calculada pela divisão das absorbâncias nos comprimentos de onde de 260 e 280 nm, que deve ficar entre 1,8 e 2,0 .

\subsection{Digestão enzimática do DNA plasmidial}

Para se verificar a integridade dos plasmídeos, foi realizado a digestão deles com as seguintes enzimas de restrição: pCAR - Notl e Xbal; pHelp1 - Pstl; pHelp2 EcoRI; pHelp3 - EcoRI. Para cada amostra plasmídeo, foram adicionados em um microtubo: $2 \mu \mathrm{L}$ de Buffer $(2 \mathrm{X}), 1 \mu \mathrm{g}$ de DNA, $1 \mu \mathrm{L}$ da respectiva enzima de restrição, e água nucleasse-free para completar o volume de $20 \mu \mathrm{L}$. Tubos foram incubados em banho seco a $37^{\circ} \mathrm{C}$ pelo tempo recomendado pelo fabricante para cada enzima de restrição. Após a digestão, as amostras foram separadas por eletroforese em gel de agarose $1 \%$ preparado com tampão TAE e comparadas com os fragmentos esperados. Foi utilizado o marcador de peso molecular GelPilot ${ }^{\circledR} 1 \mathrm{~kb}$ Plus Ladder (QIAGEN) de 10.000 pares de bases (pb) e o gel foi corado com GelRed ${ }^{\mathrm{TM}}$. O gel foi visualizado em fotodocumentador MiniBIS Pro (DNR Bio-Imaging Systems).

\subsection{Cultura de células}

3.10.1 Condições geral para cultura de células

Todas as células foram cultivadas em estufa úmida a $37^{\circ} \mathrm{C}$ e $5 \% \mathrm{CO}_{2}$. Meios de cultura e tampão PBS usados foram pré-aquecidos. A contagem das células foi realizada em câmara de Neubauer. Foi coletado $10 \mu \mathrm{L}$ do meio contendo as células e misturado com $10 \mu \mathrm{L}$ do corante Azul de Tripan. A célula cuja membrana não está intacta absorve o corante e apresenta coloração azul quando observada sob microscopia. Assim, pôde-se calcular o número de células viáveis, aquelas que não se apresentavam azuis. Foi colocado $10 \mu \mathrm{L}$ da mistura de células coradas na câmara 
de Neubauer. O número de células de 4 quadrantes $\left(\mathrm{N}^{\circ}\right)$ foi contado e a concentração de células foi calculada segundo a equação 1 abaixo representada:

$$
\text { células } / \mathrm{mL}=\frac{\mathrm{N}^{\circ}}{4} \times \text { Fator de diluição } \times 10^{4}
$$

Como forma de manter um estoque das células utilizadas, as linhagens foram congeladas em meio de congelamento (90\% soro fetal bovino inativado (SFB) e $10 \%$ dimetilsufóxido (DMSO)). Após congelamento por $24 \mathrm{~h}$ em freezer $-80^{\circ} \mathrm{C}$, os tubos contendo as células eram transferidos para tanque de nitrogênio líquido. $O$ descongelamento era feito ao se incubar por cerca de 1 minuto a $37^{\circ} \mathrm{C}$ o tubo contendo as células. O meio apropriado para a célula era adicionado e as células eram centrifugadas a $200 \times g$ por $5 \mathrm{~min}$. As células eram ressuspendidas em meio fresco e plaqueadas em frascos de cultura.

\subsubsection{Cultivo de células HEK293T}

HEK293T - linhagem celular derivada de rim embrionário humano, modificadas para maior produção de vetores lentivirais (adquirida de ATCC $^{\circledR}$ sob número de catálogo CRL-3216 ${ }^{\mathrm{TM}}$ ).

Célula cultivada em DMEM high glucose $\left(\right.$ Gibco $^{\mathrm{TM}}$ ) suplementado com 10\% SFB (HyClone ${ }^{\mathrm{TM}}$ ) em incubadora com $5 \% \mathrm{CO}_{2}$ e $80 \%$ de umidade relativa. Células repicadas $1: 10$ a cada 2 ou 3 dias. Por ser uma linhagem celular aderente ao plástico, as células precisavam ser tripsinizadas antes do replaqueamento. Para isso, as células eram lavadas com PBS e incubadas a $37^{\circ} \mathrm{C}$ por cerca de 3 min com solução de Tripsina 0,25\%. Posteriormente, a tripsina era inativada com a adição de DMEM $10 \%$ SFB, as células centrifugadas a $200 \times g$ por 6 min e o pellet ressuspendido em meio fresco.

Esta linhagem celular expressa estavelmente o gene para o grande antígeno $T$ do SV40, que leva a um aumento na produção de partículas lentivirais (GAMANORTON et al., 2011). Essas células também são resistentes a geneticina e foram selecionadas em cultura a partir da adição de G418 (ThermoFischer) ao meio de cultura para uma concentração final de $5 \mu \mathrm{L} / \mathrm{mL}$. 
3.10.3 Cultivo de demais linhagens

Jurkat - linhagem celular CD4+ derivada de leucemia linfoide aguda (cedida por Simone Kashima Haddad, Universidade de São Paulo).

Sup-B15 - linhagem celular CD19+ derivada de leucemia linfoide aguda (adquirida de ATCC $^{\circledR}$ sob número de catálogo CRL-1929 ${ }^{\mathrm{TM}}$ ).

K562 - linhagem celular CD19- derivada de leucemia mieloide crônica (cedida por Fabíola Traina, Universidade de São Paulo).

As células Jurkat, Sup-B15 e K562 foram cultivadas em RMPI (Gibco ${ }^{\mathrm{TM}}$ ) suplementado com 10\% SFB (HyClone ${ }^{\mathrm{TM}}$ ) em incubadora com 5\% $\mathrm{CO}_{2}$ e $80 \%$ de umidade relativa. Células repicadas a cada 2 ou 3 dias para que mantivessem uma concentração de $5 \times 10^{5}$ células $/ \mathrm{mL}$.

\subsection{Transfecção transiente da linhagem empacotadora HEK293T}

Foi realizada a transfecção da linhagem HEK293T com os plasmídeos produzidos anteriormente. $1 \times 10^{7}$ células foram plaqueadas em frascos T175 contendo meio DMEM 10\% SFB. No dia seguinte, estando as células com uma confluência de $60-70 \%$, foi adicionado o meio de transfecção. O meio de transfecção foi preparando adicionando-se $5 \mathrm{~mL}$ de meio DMEM sem soro, $60 \mu \mathrm{g}$ de DNA plasmidial em diferentes proporções e $180 \mu \mathrm{g}$ do polímero catiônico PEl adicionado gota-à-gota sob agitação. Após incubação à temperatura ambiente por 115 minutos, o meio de transfecção foi adicionado às células contendo $20 \mathrm{~mL}$ de DMEM $10 \%$ SFB. Após incubação overnight à $37^{\circ} \mathrm{C}$, o meio de cultivo foi trocado por DMEM $10 \%$ SFB fresco. O sobrenadante contendo as partículas lentivirais foi coletado após 48 horas de incubação. Esse meio foi centrifugado a $450 \times g$ por 5 min e filtrado $(0,45 \mu \mathrm{m})$ para retirada de debris celulares, aliquotado e congelado a $-80^{\circ} \mathrm{C}$ para posterior cálculo do título viral.

A seguinte metodologia também foi testada: o sobrenadante contendo as partículas lentivirais foi coletado, 24 horas após a transfecção, e meio DMEM 10\% SFB fresco adicionado às células. O meio coletado foi armazenado sob refrigeração até o dia seguinte. Após 48 horas pós-transfecção, o meio foi novamente coletado. Os meios coletados em 24 e $48 \mathrm{~h}$ foram misturados, centrifugados a $450 \times g$ por $5 \mathrm{~min}$, 
filtrados $(0,45 \mu \mathrm{m})$. As partículas lentivirais foram então concentradas por diferentes métodos.

Também foi testada a transfecção com o lipídeo catiônico Lipofectamine ${ }^{\circledR} 2000$, no qual $60 \mu \mathrm{g}$ de DNA plasmidial foram adicionados às células na presença de $180 \mu \mathrm{L}$ do lipídeo, segundo protocolo do fabricante. Foi testada também a adição de butirato de sódio $(\mathrm{NaBu})$ à concentração final de $5 \mathrm{mM}$ aos protocolos de transfecção com $\mathrm{PEI}$ e Lipofectamine ${ }^{\circledR}$.

\subsection{Concentração por ultracentrifugação}

Após a coleta, o sobrenadante viral foi distribuído em tubos de polipropileno e as partículas virais concentradas por ultracentrifugação a 19.200 rpm por 1 h 40 min a $4^{\circ} \mathrm{C}$ em ultracentrífuga Optima ${ }^{\mathrm{TM}}$ XL-100K (Beckman Coulter - rotor SW28, equivalente a aproximadamente $67.000 \times \mathrm{g}$ ). Posteriormente, o sobrenadante era descartado e o pellet ressuspendido em RPMI 10\% SFB 0,0001\% Pluronic-F68 $\left(\right.$ Gibco $\left.^{\circledR}\right)$ overnight sob refrigeração. Os pellets ressuspendidos foram então misturados, aliquotados e congelados em freezer $-80^{\circ} \mathrm{C}$ para posterior titulação viral e utilização.

\subsection{Concentração por filtração tangencial}

Sobrenadante viral produzido seguindo-se os protocolos descritos anteriormente. Adicionou-se o surfactante Pluronic-F68 a uma concentração final de 0,0001-0,05\% para amenizar as tensões de cisalhamento e possibilitar uma maior recuperação de partículas lentivirais viáveis. O sobrenadante foi então filtrado utilizando-se o sistema QuixStand® (GE Healthcare) com um cartucho de 100 kDa por 20 minutos, com ou sem retrolavagem do filtro com $50 \mathrm{~mL}$ de PBS. O volume final foi então concentrado por ultracentrifugação convencional como descrito anteriormente.

\subsection{Concentração por ultrafiltração em membrana}

Colunas com membrana de polietersulfona foram utilizadas para realizar a concentração do sobrenadante viral produzido como relatado anteriormente. $20 \mathrm{~mL}$ de sobrenadante foram colocados em um tubo VivaSpin ${ }^{\mathrm{TM}}$ (GE Healthcare) e centrifugado a $2000 \times g$ por $1 \mathrm{~h}$ e $30 \mathrm{~min}$ a $4^{\circ} \mathrm{C}$. O flow-through era descartado e o 
volume retido contendo as partículas virais era aliquotado e congelado em freezer $80^{\circ} \mathrm{C}$. Após a utilização os tubos de ultrafiltração foram lavados com PBS e mantidos em geladeira com etanol $70 \%$ para posterior reutilização.

\subsection{Rendimento de concentração}

O rendimento de concentração, que informa a porcentagem de partículas virais obtidas pós-concentração em relação à quantidade de partículas virais iniciais presentes no sobrenadante, foi calculado (Equação 2) para os 3 métodos de concentração avaliados.

$$
\text { Rendimento }(\%)=\frac{\text { Vírus concentrados }}{\text { Vírus iniciais }} \times 100
$$

A quantidade de vírus é dada pela multiplicação do título viral (TU/mL) pelo volume da amostra.

\subsection{Titulação lentiviral por PCR em tempo real}

O cálculo do título viral, que é o número de partículas de vetores necessárias para transduzir uma única célula em um volume definido, expresso em unidades de transfecção por mililitros ( $\mathrm{TU} / \mathrm{mL})$ feito através de análise por PCR em tempo real, utilizando a sondas $\operatorname{TaqMan}^{\circledR}$ para $\beta$-actina e para a região LTR da sequência lentiviral, segundo a equação 3 .

$$
\text { Título }\left(\frac{\mathrm{TU}}{\mathrm{mL}}\right)=\frac{\left(\left(\frac{\text { Cópias }(\mathrm{LTR})}{\text { Cópias }(\beta \text {-actina })} \times 2\right) \times \mathrm{N}^{\circ} \text { células } \times \text { Fator de diluição }\right)}{\text { Volume de vírus }}
$$

Células HEK293T foram transduzidas utilizando-se diferentes diluições do sobrenadante viral ou do vírus concentrado. A transdução foi feita placa de 6 poços com auxílio de $8 \mu \mathrm{g} / \mathrm{mL}$ de Polybrene ${ }^{\circledR}$ (Sigma) e centrifugação por 20 minutos à 1.000 rpm. Após 72 horas, o DNA das células foi extraído utilizando-se DNEasy Blood and Tissue Kit (QIAGEN).

Foi realizada então a análise por PCR em tempo real do DNA extraído junto com as curvas padrão para LTR (107 a $10^{3}$ cópias) e $\beta$-actina endógena (106 a $10^{2}$ cópias). Para esta reação foi utilizado: $5 \mu$ de gDNA, $10 \mu \mathrm{L}$ de $2 X$ TaqMan $^{\circledR}$ Universal 
PCR Master Mix (Applied Biosystems $\left.{ }^{\circledR}\right), \quad 1 \mu \mathrm{L}$ primer LTR 5' (5'TGCTTTTTGCTTGTACTGTGGG-3'), $1 \mu \mathrm{L}$ de primer LTR 3' (5'CTAGTTACCAGAGTCACACAA-3'), 0,5 $\mu \mathrm{L}$ de sonda, e água nucleasse-free para completar o volume de $2 \mu \mathrm{L}$. A reação foi submetida à seguinte termociclagem no aparelho 7500 Real-Time PCR System (Applied Biosystems ${ }^{\circledR}$ ): $50^{\circ} \mathrm{C}$ por 2 min, $95^{\circ} \mathrm{C}$ por $10 \min , 160^{\circ} \mathrm{C}$ por $1 \min (40$ ciclos).

\subsection{Titulação lentiviral por citometria de fluxo}

Em cada poço de placa de 24 poços foram plaqueadas $2 \times 10^{5}$ células Jurkat. Elas foram transduzidas com diferentes diluições de vírus e adição de $8 \mu \mathrm{g} / \mathrm{mL}$ de Polybrene $^{\circledR}$ (Sigma). As células foram então incubadas por $30 \mathrm{~min}$ a $37^{\circ} \mathrm{C}$, seguidas de centrifugação por 90 min a $1.285 \times$ g. Após a centrifugação os pellets e agregados celulares foram ressuspendidos e desfeitos com auxílio de micropipeta. Após $72 \mathrm{~h}$, as células foram coletadas e marcadas com anticorpo anti- $\mathrm{F}\left(\mathrm{abb}^{\prime}\right)_{2}$ conjugado com Alexa Fluor $^{\circledR} 647$ (Jackson Immunoresearch), para detecção do receptor CAR na superfície da célula. Para isso, as células foram coletadas, centrifugadas e ressuspendidas em $100 \mu \mathrm{L}$ de PBS $2 \%$ globulina gama de cabra (Jackson Immunoresearch). O anticorpo e o isotipo foram adicionados aos respectivos tubos e as células foram incubadas por 45 min sob refrigeração e no escuro. Posteriormente, as células foram lavadas, ressuspendidas em $200 \mu \mathrm{L}$ de PBS, adquiridas no citômetro FACSCalibur ${ }^{\mathrm{TM}}$ (Becton Dickinson) e analisadas no software FACSQuest Pro ${ }^{\mathrm{TM}}$ (Becton Dickinson).

Alternativamente também foi utilizada a marcação com Proteína L biotinilada (GenScript). A Proteína $L$ tem a capacidade de se ligar à porção variável do receptor CAR. As células coletadas, centrifugadas e incubadas por $1 \mathrm{~h}$ em PBS $4 \%$ albumina sérica humana. Posteriormente, as células foram lavadas e incubadas com a Proteína $\mathrm{L}$ biotinilada por $45 \mathrm{~min}$ no escuro e em geladeira. Em seguida, as células foram lavadas e incubadas com Estreptavidina-FITC (Becton Dickinson) por 15 minutos sob o abrigo de luz e refrigeração. Ao final da incubação, as células foram lavadas e estavam prontas para serem analisadas no citômetro.

O cálculo do título viral foi realizado segundo a equação 4 abaixo, sendo que a só foram consideradas as diluições que apresentavam valores de 5 a $20 \%$ de células positivas para o receptor CAR. Isso se faz necessário pois valores acima de $20 \%$ podem mascarar múltiplas infecções. 
Título $\left(\frac{\mathrm{TU}}{\mathrm{mL}}\right)=\frac{\left(\% \mathrm{CAR}{ }^{+} \times \mathrm{N}^{\circ} \text { células } \times \text { Fator de diluição }\right)}{\text { Volume de transdução }}$

\subsection{Transdução de linhagem celular}

Células $\mathrm{CD}^{+} \mathrm{CD} 4^{+}$Jurkat foram transduzidas com os vetores lentivirais a uma multiplicidade de infecção (MOI) de 5 e 10 em placas de 6 poços (106 células/poço) com $8 \mu \mathrm{g} / \mathrm{mL}$ de Polybrene ${ }^{\circledR}$ (Sigma) e centrifugação por 20 minutos à 1.000 rpm. Após $48 \mathrm{~h}$ da transdução, o DNA das células foi extraído com DNEasy Blood and Tissue Kit (QIAGEN) para se calcular o número de integrações virais $(\mathrm{N})$ no genoma celular (Equação 5) por PCR em tempo real como descrito anteriormente.

$$
\mathrm{N}=\frac{\text { Cópias }(\mathrm{LTR})}{\text { Cópias }(\beta \text {-actina })} \times 2
$$

\subsection{Ensaio de ativação de linhagem celular modificada}

As células Jurkat transduzidas com MOI 5 foram utilizadas em um ensaio de co-cultivo com a linhagem celular CD19+ Sup-B15. As células foram plaqueadas em poços de placa de 6 poços em uma razão de 1:5 (Jurkat:Sup-B15) em meio RMPI $10 \%$ SFB e mantidas em incubadora a $37^{\circ} \mathrm{C}$ overnight. Como controle células Jurkat não modificadas foram incubadas com Sup-B15. Além disso, células Jurkat modificadas ou não foram incubadas isoladamente. Após a incubação, as células foram coletadas e analisadas por citometria de fluxo. As células Jurkat não são células citotóxicas $\mathrm{CD}^{+}$, portanto não são capazes de induzir a morte das células CD19+ quando o receptor CAR se liga ao CD19 expresso na célula alvo, mas esta ligação leva à ativação da célula Jurkat, que leva à expressão de CD69 na superfície da célula. Esta ativação foi analisada por citometria de fluxo após marcação das células coletadas com anticorpos anti-CD3 e anti-CD69 (Becton Dickinson). Foram consideradas células efetoras ativadas, as células duplo-positivas CD3 e CD69.

\subsection{Linfócitos T primários}

\subsubsection{Coleta de PBMC}

O filtro de leucorredução proveniente do processo de doação de plaquetas foi lavado com PBS até um volume final de $60 \mathrm{~mL}$ e dividido em 2 tubos cônicos. Em 
cada tubo foi adicionado $13 \mathrm{~mL}$ de Ficoll-Paque ${ }^{\mathrm{TM}}$ PLUS (GE Healthcare). Tubos foram centrifugados a $800 \times g$ por $30 \mathrm{~min}$, sem freio. A interfase contendo as células mononucleares do sangue periférico (PBMC) foi coletada e transferida para um novo tubo cônico. As células foram lavadas 3 vezes com PBS (450 × g por $10 \mathrm{~min})$. As células foram então contadas em câmara de Neubauer. Um determinado número de células foi separado para realização do isolamento de linfócitos $T$, enquanto as demais células foram armazenadas congeladas.

\subsubsection{Isolamento dos linfócitos T}

Os linfócitos $\mathrm{T}\left(\mathrm{CD} 3^{+} \mathrm{CD} 4^{+}\right.$e $\left.\mathrm{CD} 3^{+} \mathrm{CD} 8^{+}\right)$foram isolados por seleção magnética utilizando-se os kits comerciais: EasySep ${ }^{\mathrm{TM}}$ Human CD3 Positive Selection Kit $\left(\right.$ StemCell $\left.{ }^{\mathrm{TM}}\right)$, que realiza o isolamento positivo das células $\mathrm{CD}^{+}$; EasySep ${ }^{\mathrm{TM}}$ Human $\mathrm{CD}^{+} \mathrm{T}$ Cell Enrichment Kit (StemCell ${ }^{\mathrm{TM}}$ ), que isola as células CD4 ${ }^{+}$negativamente; e EasySep ${ }^{\mathrm{TM}}$ Human $\mathrm{CD}^{+} T$ Cell Enrichment Kit (StemCell ${ }^{\mathrm{TM}}$ ), que seleciona negativamente as células $\mathrm{CD}^{+}$. Todos os isolamentos foram feitos seguindo as instruções do fabricante. Ao final da seleção negativa de células $\mathrm{CD}^{+}{ }^{+}$e CD8 ${ }^{+}$, os linfócitos $\mathrm{T}$ isolados foram misturados.

\subsubsection{Ativação dos linfócitos T}

Os linfócitos $\mathrm{T}$ isolados foram então ativados utilizando-se beads magnéticas anti-CD3/CD28 (Dynabeads human T-activator CD3/CD28 - Gibco ${ }^{\mathrm{TM}}$ ) em proporção 1:1 (células:beads). A ativação feita seguindo-se as instruções do fabricante foi

realizada em placas de 48 poços e uma concentração celular de $1 \times 10^{6}$ células/mL/poço. A placas foram incubadas por $24 \mathrm{~h}$ a $37^{\circ} \mathrm{C}, 5 \% \mathrm{CO}_{2}$.

\subsubsection{Cultivo in vitro de linfócitos T}

Após $24 \mathrm{~h}$ de incubação, parte dos linfócitos T ativados foram transduzidos com vetores lentivirais para expressão do receptor CAR. O restante dos linfócitos foi cultivado sem realização da transdução. O cultivo dos linfócitos $T$, transduzidos ou não, foi realizado a uma concentração de $7,5 \times 10^{5}$ células $/ \mathrm{mL}$ em RPMI (Gibco ${ }^{\mathrm{TM}}$ ) com $10 \%$ soro humano AB suplementado com $100 \mathrm{UI} / \mathrm{mL}$ de IL-2 (GE Healthcare). As células foram plaqueadas a uma concentração de $3 \times 10^{5}$ células $/ \mathrm{cm}^{2}$. A cada $48 \mathrm{~h}$ o 
número de células era contado e meio adicionado para se manter a concentração de $7,5 \times 10^{5}$ células $/ \mathrm{mL}$.

\subsubsection{Remoção das beads}

Dia 8 após a ativação dos linfócitos $\mathrm{T}$, as beads magnéticas de ativação foram retiradas da cultura. Para a remoção, o meio contendo as células foi colocado em tubo cônico de $15 \mathrm{~mL}$ sob campo magnético por $5 \mathrm{~min}$, as beads que foram atraídas pelo ímã foram descartadas e o procedimento repetido por mais duas vezes. As células foram cultivadas a uma concentração de $1 \times 10^{6}$ células $/ \mathrm{mL}$.

\subsection{Imunofenotipagem por citometria de fluxo}

Células coletadas foram transferidas para tubos de citometria e lavadas com PBS. Após centrifugação por 3 min a 1.800 rpm, o sobrenadante era removido e as células ressuspendidas em $100 \mu \mathrm{L}$ de PBS. Os anticorpos monoclonais (Becton Dickinson) e isotipo controle foram adicionados aos respectivos tubos e as células foram incubadas por 15 min à temperatura ambiente e sob abriga da luz. Ao final da incubação, as células foram lavadas novamente com PBS, centrifugadas e ressuspendidas em $200 \mu \mathrm{L}$ de PBS. A aquisição das células era feita no citômetro FACSCalibur $^{\mathrm{TM}}$ (Becton Dickinson) e a análise no software FACSQuest Pro ${ }^{\mathrm{TM}}$ (Becton Dickinson).

\subsection{Transdução de linfócitos T primários}

Linfócitos T ativados foram plaqueados em poços de placa de 24 poços a uma concentração de $1 \times 10^{6}$ células $/ \mathrm{mL}$ em $500 \mu \mathrm{L}$ de meio RPMI com $100 \mathrm{UI} / \mathrm{mL}$ de IL2, suplementado ou não com $10 \%$ de soro humano $A B$. Foram adicionados vetores lentivirais a uma MOI de 5 e Polybrene ${ }^{\circledR}$ a uma concentração de $8 \mu \mathrm{g} / \mu \mathrm{L}$. As células foram incubadas por $30 \mathrm{~min}$ a $37^{\circ} \mathrm{C}$, centrifugadas a $1285 \times \mathrm{g}$ por $90 \mathrm{~min} \mathrm{e}$ ressuspendidas com auxílio de micropipeta. Após incubação overnight, adicionou-se $1 \mathrm{~mL}$ de RPMI 10\% soro humano AB em cada poço. As células foram analisadas por citometria de fluxo, 72 h pós-transdução, para avaliação da expressão do receptor CAR em sua superfície. As células foram marcadas com anticorpo anti-F(ab') 2 como descrito anteriormente. 


\subsection{Ensaio de citotoxicidade in vitro - citometria}

Para que pudessem ser identificadas durante a aquisição e análise por citometria de fluxo, as células alvo (Sup-B15 e K562) foram coradas com o PKH67 (Sigma). O PKH67 incorpora uma fluorescência verde nas regiões lipídicas das membranas. O protocolo de coloração descrito pelo fabricante foi seguido.

O co-cultivo de células efetoras e alvo foi realizado em uma proporção de 10:1 (efetora:alvo). Em poços de placa de 24 poços, foram plaqueadas $5 \times 10^{4}$ células alvo junto com $5 \times 10^{5}$ células efetoras em um volume de $1 \mathrm{~mL}$ de RPMI $10 \%$ SFB suplementado com IL-2 $100 \mathrm{UI} / \mathrm{mL}$. A célula CD19+ Sup-B15 e a células CD19- K562 foram escolhidas como alvo. Os linfócitos T-CAR e linfócitos T não modificados foram utilizados como células efetoras. As placas foram incubadas a $37^{\circ} \mathrm{C}$ e $5 \% \mathrm{CO}_{2}$. No início e após $24 \mathrm{~h}$ do co-cultivo, as células foram analisadas por citometria de fluxo. A análise da citotoxicidade foi realizada considerando-se a porcentagem de células alvo $\left(\mathrm{PKH}_{67^{+}}\right)$presentes ao final do co-cultivo.

\subsection{Ensaio de citotoxicidade in vitro - LDH}

Lactato desidrogenase (LDH) é uma enzima presente no citosol celular. Quando a membrana plasmática é danificada a LDH é liberado no meio de cultivo e pode quantificada por meio de reações enzimáticas. LDH catalisa a conversão de lactato em piruvato pela redução de $\mathrm{NAD}^{+}$em $\mathrm{NADH}$. A enzima diaforase então utiliza - NADH para reduzir um sal tetrazólio no corante vermelho formazana. A quantidade deste corante pode ser medida espectrofotometricamente a $490 \mathrm{~nm}$. Para a quantificação de LDH utilizou-se o kit comercial TOX7 (LDH-based In Vitro Toxicology Assay Kit, Sigma-Aldrich $\left.{ }^{\circledR}\right)$.

Para determinação do número ideal de células alvo, uma diluição seriada de células alvo (Sup-B15 e K562, 0 a $2 \times 10^{4}$ células/100 $\mu \mathrm{L}$ ) foi preparada e plaqueada em dois conjuntos de triplicatas em uma placa de 96 poços. A placa foi então incubada a $37^{\circ} \mathrm{C}, 5 \% \mathrm{CO}_{2}$ overnight. Adicionou-se $10 \mu \mathrm{L}$ de água ultrapura estéril a um conjunto de triplicatas (Controle de LDH Espontâneo) e $10 \mu \mathrm{L}$ de LDH Assay Lysis Solution ao outro conjunto de triplicatas (Controle de LDH Máximo). Após incubação a $37^{\circ} \mathrm{C}$ por $45 \mathrm{~min}, 50 \mu \mathrm{L}$ de cada poço foi transferido para uma nova placa de 96 poços. $100 \mu \mathrm{L}$ de LDH Assy Mixture (mistura preparada imediatamente antes ao uso, contendo 
volumes iguais de LDH Assay Substrate Solution, LDH Assay Cofactor Preparation e LDH Assay Dye Solution) foram adicionados a cada poço e a placa foi incubada à temperatura ambiente e ao abrigo de luz por 30 min. A reação foi interrompida ao se adicionar $15 \mu \mathrm{L}$ de $\mathrm{HCl}(1 \mathrm{~N}$ ) a cada poço. A placa foi lida no espectrofotômetro SpectraMax ${ }^{\circledR}$ M5 (Molecular Devices) a $490 \mathrm{~nm}$ e $690 \mathrm{~nm}$. A atividade da LDH é dada pela subtração da absorbância a 690 nm (background do instrumento) da absorbância a $490 \mathrm{~nm}$.

O co-cultivo em triplicata de células efetoras (Linfócitos T-CAR e Linfócitos T não modificados) com células alvo (Sup-B15, K562 e PBMC de pacientes CD19+) na proporção de 1:1 e 5:1 (efetora:alvo) foi realizado em $100 \mu \mathrm{L}$ de RPMI 10\% soro humano $A B$ em poços de placa de 96 poços. Os seguintes controles experimentais foram utilizados:

a) Liberação Espontânea de LDH pela Célula Efetora (ECE): poços em triplicata contendo as células efetoras plaqueadas nas quantidades utilizadas nos poços experimentais.

b) Liberação Espontânea de LDH pela Célula Alvo (ECA): poços em triplicata contendo as células alvo na quantidade utilizada nos poços experimentais.

c) Liberação Máxima de LDH pela Célula Alvo (MCA): poços em triplicata contendo as células alvo na quantidade utilizada nos poços experimentais.

d) Correção de Volume (CV): poços em triplicata contendo $100 \mu \mathrm{L}$ de meio de cultivo.

e) Background do Meio de Cultivo (BMC): poços em triplicata contendo $100 \mu \mathrm{L}$ de meio de cultivo.

Adicionou-se $10 \mu \mathrm{L}$ de água ultrapura estéril aos poços contendo os controles Liberação Espontânea de LDH pela Célula Efetora e pela Célula Alvo. A placa foi incubada a $37^{\circ} \mathrm{C}$ por 24 h. 45 minutos antes de coletar-se o meio de cultivo, foi adicionado $10 \mu \mathrm{L}$ LDH Assay Lysis Solution aos controles Liberação Máxima de LDH pela Célula Alvo e Correção de Volume e a placa incubada a $37^{\circ} \mathrm{C}$ por $45 \mathrm{~min}$. Ao final da incubação a placa foi centrifugada a $250 \times$ g por 3 min e o $50 \mu \mathrm{L}$ de sobrenadante de cada poço foi transferido para uma nova placa de 96 poços. Foi adicionado $100 \mu \mathrm{L}$ de LDH Assy Mixture em cada poço e a placa foi incubada no escuro por 30 min à temperatura ambiente. A reação foi interrompida ao adicionando-se $15 \mu \mathrm{L}$ de $\mathrm{HCl}(1$ 
N) a cada poço. A placa foi lida no espectrofotômetro SpectraMax ${ }^{\circledR}$ M5 (Molecular Devices) a $490 \mathrm{~nm}$ e $690 \mathrm{~nm}$. A atividade da LDH é dada pela subtração da absorbância a 690 nm (background do instrumento) da absorbância a 490 nm.

Para se calcular os valores corrigidos, foi subtraído o valor médio do controle Background do Meio de Cultivo dos valores médios dos poços Experimentais, e dos controles Liberação Espontânea de LDH pela Célula Efetora e pela Célula Alvo. O valor médio do controle Correção de Volume foi substituído do valor médio do controle Liberação Máxima de LDH pela Célula Alvo. O cálculo da porcentagem de citotoxicidade foi realizada seguindo a equação 6 abaixo:

$$
\% \text { Citotoxicidade }=\frac{\text { Valor Experimental }- \text { ECE }- \text { ECA }}{\text { MCA }- \text { ECA }} \times 100
$$

\subsection{Análise estatísticas}

Para as análises estatísticas foi utilizado o software SigmaStat 4.0 (Systat Software) e foram utilizados o Teste $t$ de Student, Teste $U$ de Mann-Whitney, ou Análise de Variância (ANOVA) um ou dois fatores seguido do teste post hoc HolmSidak, dependendo do tipo de valor analisado. $\mathrm{P}<0,05$ foi considerado estatisticamente significativo. 


\section{Resultados}




\section{RESULTADOS}

\subsection{Verificação da integridade dos vetores plasmidiais}

Os 4 vetores plasmidiais foram produzidos nas bactérias E. coli Stb/3 ${ }^{\mathrm{TM}}$. Uma amostra de DNA de cada plasmídeo foi então digerida com enzimas de restrição para podermos verificar a integridade parcial da sua sequência de nucleotídeos comparando o tamanho dos fragmentos obtidos ao tamanho relatado pelo fornecedor dos plasmídeos.

O vetor pCAR, que possui o transgene para expressão do receptor quimérico de antígenos (CAR) anti-CD19, foi digerido com as enzimas Xbal e Notl e o produto da digestão deve resultar em uma banda de 8037 pb e uma de 1501 pb. O plasmídeo pHelp1, que possui os genes necessário para o empacotamento da partícula viral, foi digerido com Pstl, e o produto de digestão deve resultar nas bandas: 6767, 1424 e 927 pb. O vetor pHelp2, que possui o gene para o envelope viral VSV-G, e o pHelp3, que contém o gene que auxilia no empacotamento, foram digeridos com a enzima de restrição EcoRl. Após a digestão pHelp2 deve apresentar as bandas 3596, 1668, e 787 pb, e pHelper3, 3880 e 300 pb.

Os produtos das digestões foram separados por eletroforese em gel de agarose $1 \%$ (Figura 7) junto com marcador de peso molecular GelPilot ${ }^{\circledR} 1 \mathrm{~kb}$ Plus Ladder (QIAGEN) de 10.000 pares de bases. 
Figura 7 - Visualização dos fragmentos gerados após digestão enzimática dos vetores plasmidiais

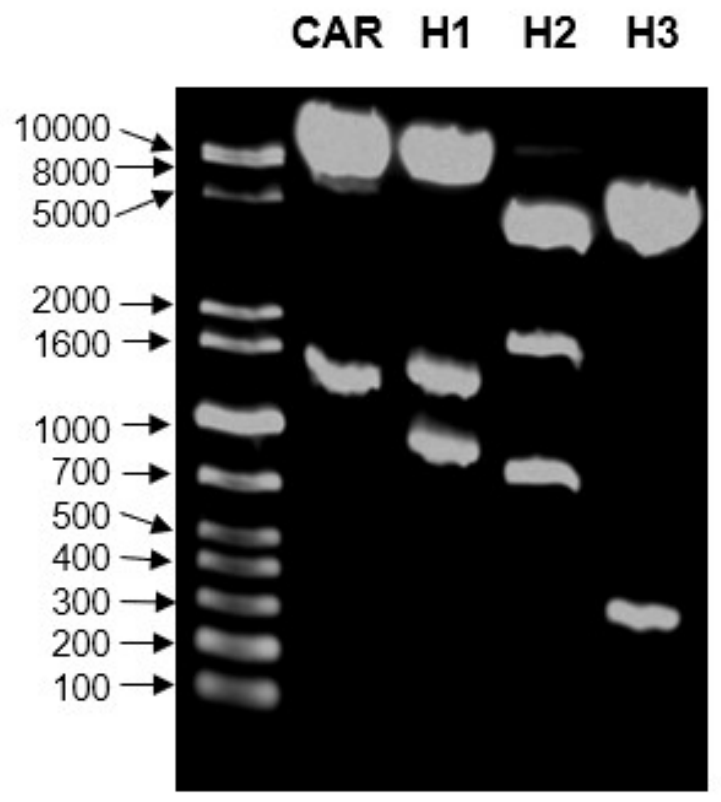

Eletroforese em gel de agarose $1 \%$ dos produtos de digestão dos vetores pCAR (CAR), pHelp1 (H1), pHelp2 (H2) e pHelp3 (H3). Marcador de peso molecular de $1 \mathrm{~kb}$.

Todos os 4 vetores plasmidiais digeridos apresentaram fragmentos de tamanho semelhantes ao esperado, confirmando a identidade dos vetores.

\subsection{Produção das partículas lentivirais e determinação do título viral}

Para testar a funcionalidade do vetor CAR anti-CD19, foi realizada uma cotransfecção com os 4 plasmídeos (produzidos anteriormente) em células HEK293T para que fossem produzidas as partículas lentivirais. A transfecção foi mediada por $\mathrm{PEI}$, polímero catiônico que forma um complexo com o DNA e neutraliza suas cargas negativas, facilitando a entrada do DNA exógeno na célula. A quantificação da produção lentiviral foi realizada por dois métodos: qPCR e por citometria de fluxo (Figura 8). 
Figura 8 - Comparação dos métodos de cálculo do título viral

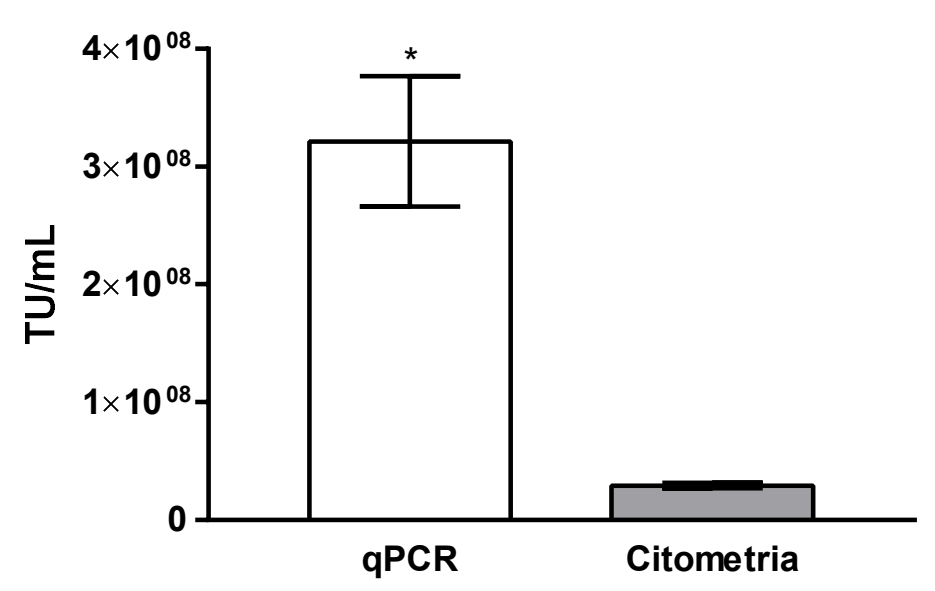

Título viral $(\mathrm{TU} / \mathrm{mL})$ calculado por PCR quantitativo em tempo real (qPCR) e por citometria de fluxo. Média \pm desvio padrão, $n=4$. ${ }^{*} P<0,05$ (Teste $U$ de Mann-Whitney).

Houve uma diferença de aproximadamente 10 vezes no título obtido com os 2

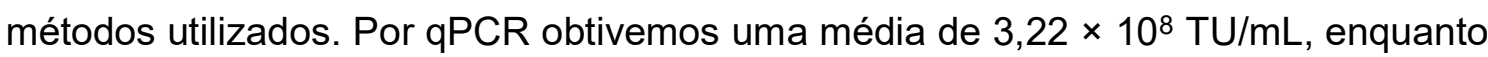
por citometria de fluxo obtivemos uma média de $2,90 \times 10^{7} \mathrm{TU} / \mathrm{mL}$. A titulação por citometria foi escolhida como a padrão para a realização dos demais experimentos, uma vez que através dessa metodologia é possível se verificar a expressão do receptor CAR na superfície da célula. Enquanto que por qPCR, a quantificação pode estar detectando múltiplas integrações, mas não a expressão do gene.

\subsection{Otimização da produção de vetores lentivirais para CAR anti-CD19}

Como a produção lentiviral estava resultando em títulos baixos e incompatíveis com o necessário para se infectar um grande número de células, partimos para a otimização da produção. Nesta etapa, determinamos o número de coletas do sobrenadante viral a serem realizadas, o efeito da proporção de plasmídeos utilizados e o efeito da adição de butirato de sódio às transfecções com PEI e lipídeo catiônico. Três métodos de concentração das partículas lentivirais também foram avaliados: ultracentrifugação, filtração tangencial e ultrafiltração sobre membrana.

\subsubsection{Determinação do número de coletas do sobrenadante}

Como forma de se otimizar a produção das partículas lentivirais, decidimos testar o efeito do tempo de coleta do sobrenadante viral. Realizamos a produção de 
vírus transfectando transientemente células HEK293T, como descrito anteriormente, e coletamos o sobrenadante viral de 3 modos diferentes:

a) Coleta única do volume total 24 horas pós-transfecção;

b) Coleta única do volume total 48 horas pós-transfecção;

c) Coleta do volume total 24 horas pós-transfecção, seguido de adição de meio de cultivo e coleta final do volume total 48 horas pós-transfecção.

Os sobrenadantes coletados foram concentrados por ultracentrifugação e o título viral (Figura 9) foi calculado por citometria de fluxo.

Figura 9 - Efeito do tempo de coleta do sobrenadante viral

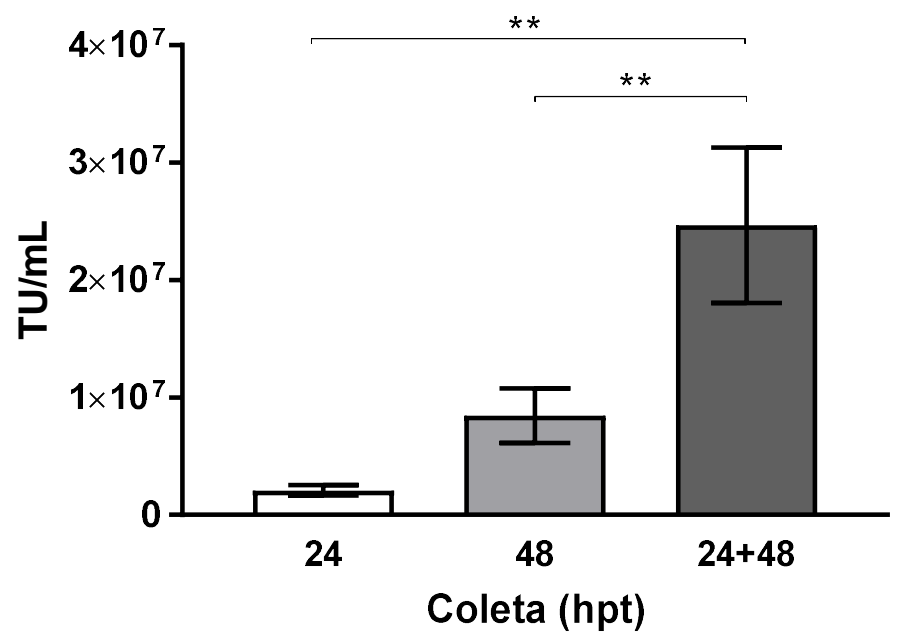

Título viral $(\mathrm{TU} / \mathrm{mL})$ obtido de diferentes coletas do sobrenadante viral. Coleta única 24 horas póstransfecção (hpt), coleta única $48 \mathrm{hpt}$, e duas coletas 24 e $48 \mathrm{hpt}$. Média \pm desvio padrão, $\mathrm{n}=3$. ${ }^{*} \mathrm{P}<$ 0,002 (ANOVA seguida de Holm-Sidak).

Na coleta única 24 horas pós-transfecção obtivemos um título médio de 2,1 $\times$ $10^{6} \mathrm{TU} / \mathrm{mL}$ e na coleta única 48 horas após a transfecção obtivemos a média de 8,45 $\times 10^{6} \mathrm{TU} / \mathrm{mL}$. Realizando 2 coletas do sobrenadante obtivemos uma média de 2,47 $\times$ $10^{7} \mathrm{TU} / \mathrm{mL}$. O terceiro modo com 2 coletas se mostrou mais vantajoso, pois obtivemos um título viral aproximadamente 3 vezes maior.

\subsubsection{Determinação da proporção dos plasmídeos}

Com o intuito de melhorar ainda mais a produção de partículas lentivirais, partimos da hipótese que o tamanho do plasmídeo (em kb) pode afetar a eficiência de transfecção, portanto diminuindo a produção lentiviral. Para testar esta hipótese, 
realizamos uma transfecção usando a proporção de 3:1:1:1 (pCAR:pHelp1:pHelp2:pHelp3), proporção esta que foi utilizada nos experimentos anteriores. Com esta proporção aumentamos 3 vezes a quantidade do nosso vetor de expressão, o pCAR. Para tentar aumentar a produção, normalizamos a quantidade de DNA de cada vetor de acordo com o seu tamanho $(\mathrm{kb})$. A proporção dos plasmídeos levando em consideração os seus tamanhos seria: 2,5:2:1,3:1 (pCAR:pHelp1:pHelp2:pHelp3). Resolvemos dobrar a quantidade do vetor de expressão pCAR com o intuito de aumentar ainda mais o título viral, e utilizamos a proporção 4:2,6:1,4:1 (pCAR:pHelp1:pHelp2:pHelp3).

Na Figura 10 estão representados os títulos virais médios de 2,85 × $10^{7}$ e 2,98 $\times 10^{7} \mathrm{TU} / \mathrm{mL}$, para as proporções 3:1:1:1 e 4:2,6:1,4:1, respectivamente. Não houve diferença estatística entre os grupos e a proporção recomendada pelo fornecedor foi utilizada para os experimentos posteriores.

Figura 10 - Efeito da proporção de plasmídeos na produção viral

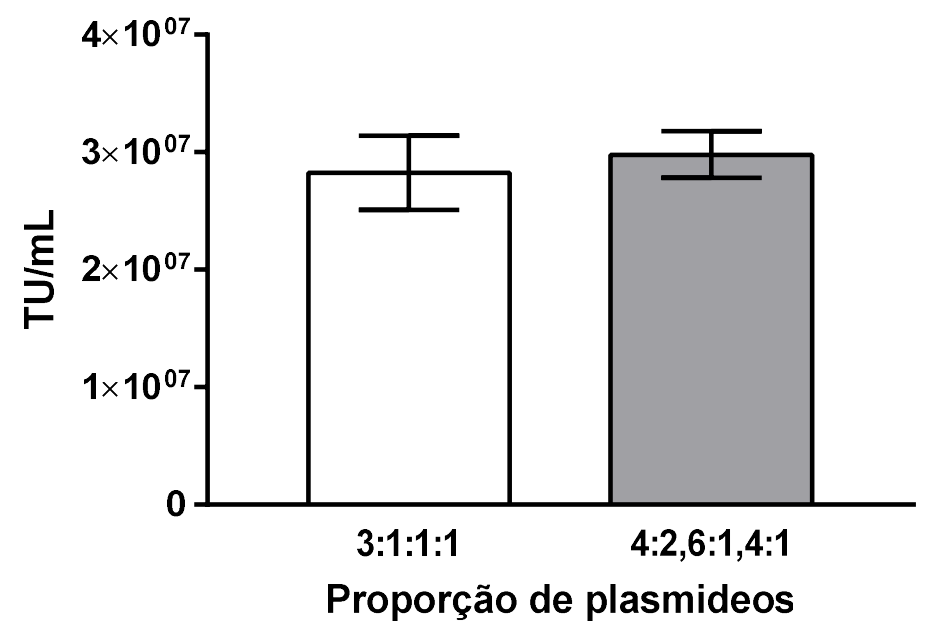

Título viral (TU/mL) utilizando-se diferentes proporções dos plasmídeos (pCAR:pHelp1:pHelp2:pHelp3). Média \pm desvio padrão, $n=2$. Diferença não significativa (Teste $U$ de Mann-Whitney).

\subsubsection{Adição de butirato de sódio}

O butirato de sódio ( $\mathrm{NaBu}$ ) é um inibidor de histona deacetilases. Ele melhora a produção lentiviral, pois previne a compactação do DNA, facilitando a acessibilidade dos promotores e aumentando a transcrição (JAALOUK et al., 2006). No momento da 
transfecção das células HEK293T, adicionamos o butirato de sódio a uma concentração final de $5 \mathrm{mM}$. A coleta e concentração foi realizada como descritas anteriormente. A adição de $\mathrm{NaBu}$ resultou em um aumento de mais de 3 vezes no título viral obtido (Figura 11), passando de 2,05 × $10^{7}$ para 7,05 × 107 TU/mL.

Figura 11 - Efeito do Butirato de Sódio na produção viral

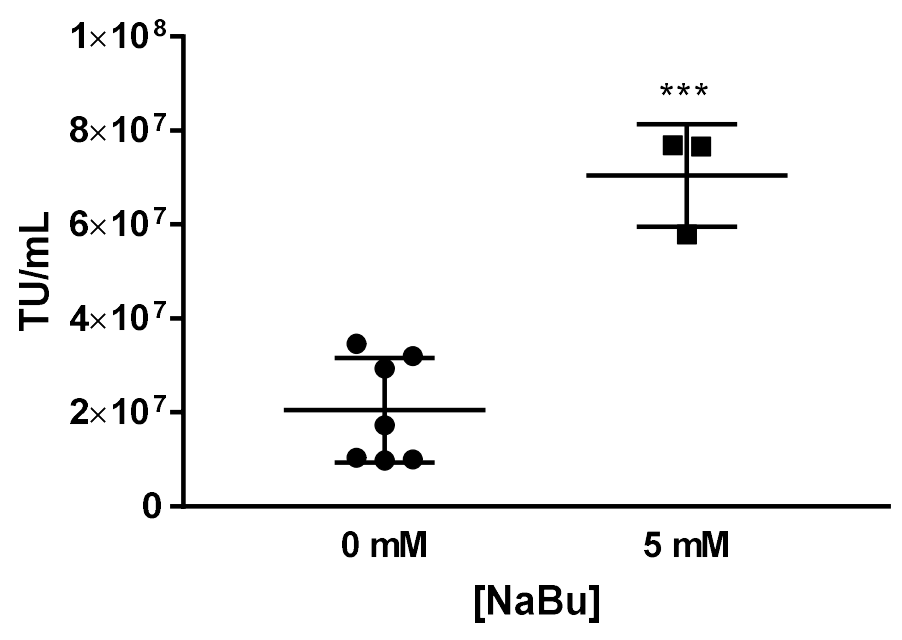

Título viral ( $\mathrm{TU} / \mathrm{mL}$ ) obtido na presença ou ausência de butirato de sódio ( $\mathrm{NaBu}$ ). Média \pm desvio padrão, número de replicatas indicado pela quantidade de pontos. ${ }^{* * *} \mathrm{P}<0,0002$ (Teste $t$ de Student).

\subsubsection{Transfecção transiente com lipossomo catiônico (Lipofectamine ${ }^{\circledR}$ )}

Todas as transfecções anteriores foram realizadas utilizando o polímero PEI, que é um polímero de baixo custo e possui uma boa taxa de transfecção. No entanto, os títulos obtidos (mesmo utilizando $\mathrm{NaBu}$ ) não são suficientes para transduzir linfócitos T de pacientes. Com intuito de aumentar o título viral, além do PEI, testamos um lipossomo catiônico (Lipofectamine ${ }^{\circledR} 2000$ ), que é um reagente com um custo mais elevado, mas que apresenta alta eficiência de transfecção. A Lipofectamine ${ }^{\circledR}$ forma um lipossomo catiônico com as moléculas negativamente carregadas de DNA, evitando que essas cargas sejam repelidas pela membrana celular. Assim, esse lipossomo formado pode se fundir à membrana celular, permitindo que o DNA seja introduzido na célula. A Figura 12 mostra a produção de partículas lentivirais utilizando-se PEI ou o lipídeo catiônico na presença ou ausência de $\mathrm{NaBu}$. 
Figura 12 - Otimização da produção dos vetores lentivirais

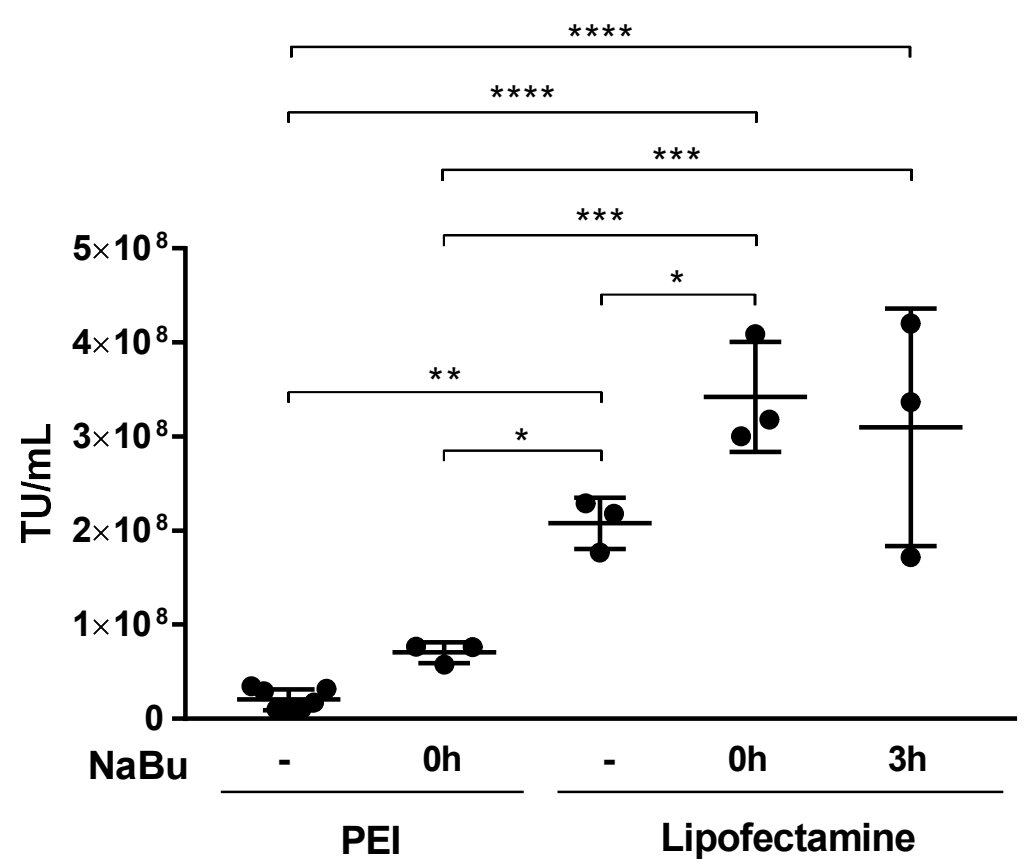

Título viral (TU/mL) obtido após produção utilizando-se Polietilenoimina (PEI), e Lipofectamine ${ }^{\circledR} 2000$ (Lipofectamine) na ausência ou presença de butirato de sódio ( $\mathrm{NaBu}$, concentração final de $5 \mathrm{mM}$ ). $\mathrm{O}$ $\mathrm{NaBu}$ foi adicionado no momento da transfecção (Oh) ou após 3 horas da transfecção (3h). Média \pm desvio padrão, número de replicatas indicado pela quantidade de pontos, ${ }^{*} \mathrm{P}<0,05$; ${ }^{* *} \mathrm{P}<0,002$; ${ }^{* * *}$ $\mathrm{P}<0,0002 ;{ }^{* * * *} \mathrm{P}<0,0001$ (ANOVA seguida de Holm-Sidak).

Na Figura 12 é possível observar um incremento de aproximadamente 3 vezes no título viral obtido na transfecção com Lipofectamine $^{\circledR} 2000$ em relação à produção

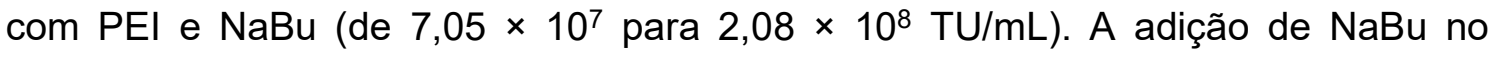
momento da transfecção com Lipofectamine ${ }^{\circledR} 2000$ resultou quase no dobro do título

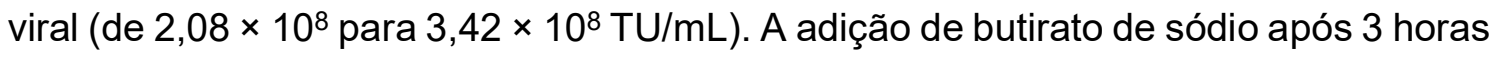
da transfecção não levou a um aumento significativo do título obtido em relação à produção com Lipofectamine ${ }^{\circledR} 2000$ e adição de NaBu no momento da transfecção.

\subsubsection{Concentração das partículas lentivirais}

\subsubsection{Ultracentrifugação}

O método padrão de concentração das partículas lentivirais utilizado nesse estudo foi a ultracentrifugação. Porém ela teve um rendimento médio de 53,91\% (Figura 13). Isso significa que pouco mais da metade das partículas iniciais permaneciam viáveis após a concentração. 
Figura 13 - Recuperação de partículas virais pré e pós-concentração

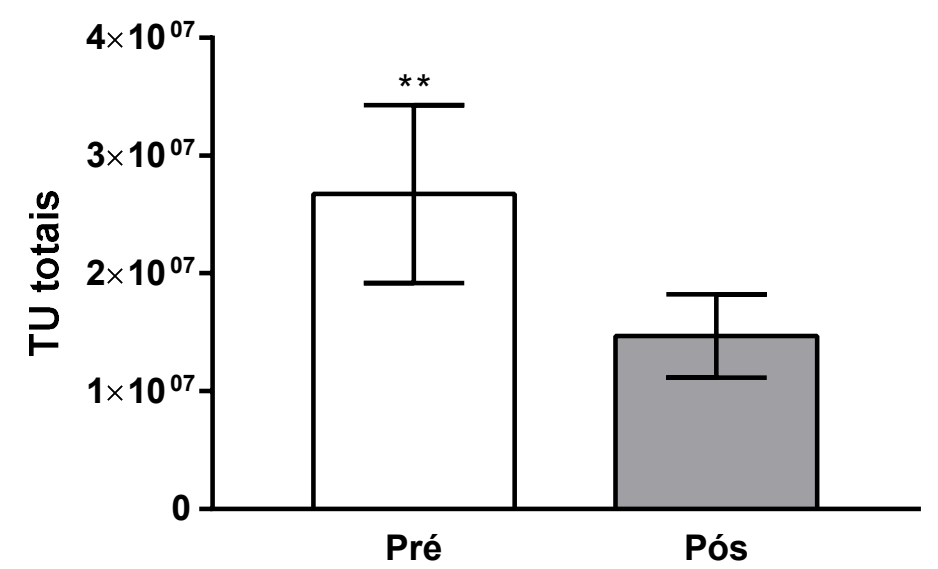

Partículas virais (TU) obtidas pré e pós-concentração por ultracentrifugação. Média \pm desvio padrão, $n=5 .{ }^{*} \mathrm{P}<0,05$ (Teste U de Mann-Whitney).

Como forma de aumentar esse rendimento, testamos dois outros métodos de concentração:

a) Ultrafiltração tangencial;

b) Ultrafiltração por centrifugação sobre membrana.

\subsubsection{Filtração tangencial}

A filtração tangencial permite a concentração de grandes volumes em um curto período, podendo ser implementada como um passo anterior à concentração por ultracentrifugação. Assim, produziu-se $400 \mathrm{~mL}$ de sobrenadante viral, utilizando-se PEI como agente de transfecção e sem adição de butirato de sódio. Adicionou-se o surfactante Pluronic ${ }^{\circledR} F-68$ a uma concentração final de $0,0001 \%$ para proteger as partículas lentivirais, amenizar efeitos das tensões de cisalhamento e possibilitar uma maior recuperação de partículas lentivirais viáveis. O sobrenadante foi então filtrado utilizando-se o QuixStand ${ }^{\circledR}$ com um cartucho de 100 kDa.

$\mathrm{Na}$ Tabela 3 temos os resultados da quantificação lentiviral do sobrenadante pré-concentração, do permeado (volume a ser descartado) e do meio filtrado concentrado. Houve uma perda de apenas $1 \%$ das partículas virais viáveis no permeado, como era esperado. No entanto, observou-se uma perda de cerca de $40 \%$ dos vírus no processo de filtração. 
Tabela 3 - Teste QuixStand 1 - Eficiência da filtração tangencial de sobrenadante contendo vetores lentivirais.

\begin{tabular}{lrrrrr}
\hline & Volume (mL) & Título (TU/mL) & TU total & Rendimento (\%) & Perda (\%) \\
\hline Sobrenadante & 400 & $5,39 \times 10^{4}$ & $2,16 \times 10^{7}$ & - & - \\
Permeado & 350 & $6,80 \times 10^{2}$ & $2,38 \times 10^{5}$ & - & 1,10 \\
Filtrado & 50 & $2,61 \times 10^{5}$ & $1,30 \times 10^{7}$ & 60,18 & 39,82 \\
\hline
\end{tabular}

Como forma de diminuir as perdas de partículas virais viáveis durante o processo de filtração tangencial, decidiu-se aumentar a concentração de Pluronic-F68 presente no sobrenadante. Assim, realizou-se uma nova produção de lentivírus com adição de maior quantidade de Pluronic ${ }^{\circledR}$ F-68 (concentração final de 0,05\%). Ao final da filtração, realizou-se também a retrolavagem do cartucho de fibra oca com PBS para maximizar a recuperação (Tabela 4). Apesar de não detectarmos perda de partículas viáveis no permeado, o rendimento de filtração foi de apenas $31,37 \%$. Esse resultado nos permitiu inferir que a quantidade de Pluronic ${ }^{\circledR}$ F-68 pode ter sido tóxica para os vírus, diminuindo drasticamente a viabilidade deles.

\begin{tabular}{|c|c|c|c|c|c|}
\hline & Volume (mL) & Título (TU/mL) & TU total & Rendimento (\%) & Perda (\%) \\
\hline Sobrenadante & 400 & $1,11 \times 10^{5}$ & $4,43 \times 10^{7}$ & - & - \\
\hline Permeado & 350 & 0 & 0 & - & 0 \\
\hline Filtrado & 130 & $1,07 \times 10^{5}$ & $1,39 \times 10^{7}$ & 31,37 & 68,63 \\
\hline
\end{tabular}

Uma nova produção foi realizada com adição de Pluronic ${ }^{\circledR}$ F-68 em uma concentração final de $0,001 \%$. Ao final da filtração, realizou-se também a retrolavagem do cartucho de fibra oca com PBS para maximizar a recuperação. Diferente dos testes anteriores, neste experimento detectamos uma perda de aproximadamente $25 \%$ das partículas lentivirais no permeado. Além disso, o rendimento de filtração foi de apenas $38,98 \%$ (Tabela 5). 
Tabela 5 - Teste QuixStand 3 - Eficiência da ultrafiltração tangencial de sobrenadante contendo vetores lentivirais.

\begin{tabular}{lrrrrr}
\hline & Volume (mL) & Título (TU/mL) & TU total & Rendimento (\%) & Perda (\%) \\
\hline Sobrenadante & 400 & $4,42 \times 10^{5}$ & $1,77 \times 10^{8}$ & - & - \\
& & & & & \\
Permeado & 350 & $1,25 \times 10^{5}$ & $4,38 \times 10^{7}$ & - & 24,74 \\
Filtrado & 134 & $5,15 \times 10^{5}$ & $6,90 \times 10^{7}$ & 38,98 & 60,95 \\
\hline
\end{tabular}

Os volumes finais obtidos (de 50 a $134 \mathrm{~mL}$ ) possuíam uma titulação baixa, da ordem de $10^{5} \mathrm{TU} / \mathrm{mL}$. Desse modo se faz necessária a concentração desse volume por ultracentrifugação, e a quantidade final de vírus obtidos no final da filtração tangencial seguida de ultracentrifugação estão na Tabela 6.

Tabela 6 - Partículas virais recuperadas após a filtração tangencial seguida de ultracentrifugação.

TU iniciais TU finais Rendimento (\%)

\begin{tabular}{lllr}
\hline Teste 1 & $2,16 \times 10^{7}$ & $5,47 \times 10^{6}$ & 25,34 \\
Teste 2 & $4,43 \times 10^{7}$ & $2,22 \times 10^{6}$ & 5,01 \\
Teste 3 & $1,77 \times 10^{8}$ & $4,23 \times 10^{7}$ & 23,93 \\
\hline
\end{tabular}

\subsubsection{Ultrafiltração - Centrifugação sobre membrana}

Para diminuir a perda de partículas virais concentradas por ultracentrifugação ou filtração tangencial testamos a ultrafiltração do sobrenadante contendo as partículas virais em membrana de polietersulfona com corte de peso molecular (MWCO) de aproximadamente $100 \mathrm{kDa}$. Na Figura 14 temos o resultado da ultrafiltração e a comparação com a ultracentrifugação e filtração tangencial. $O$ rendimento médio de concentração por ultrafiltração foi de $81,80 \%$, significativamente superior aos demais métodos de concentração. 
Figura 14 - Rendimento de concentração dos métodos analisados

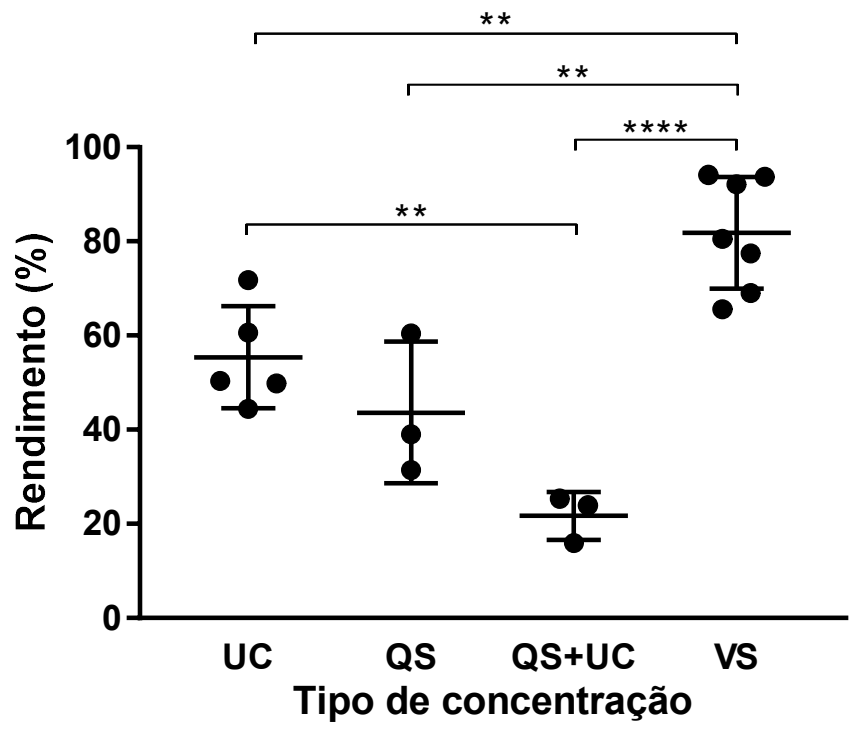

Ultracentrifugação (UC), filtração tangencial (QuixStand - QS), filtração tangencial seguida de ultracentrifugação (QS + UC), ultrafiltração por centrifugação sobre membrana (VivaSpin - VS). Média \pm desvio padrão, número de replicatas indicado pela quantidade de pontos, ${ }^{* *} \mathrm{P}<0,002$; ${ }^{* * * *} \mathrm{P}<0,0001$ (ANOVA seguida de Holm-Sidak).

\subsection{Ensaio funcional da molécula CAR anti-CD19}

\subsubsection{In vitro}

Para nos certificarmos que os linfócitos $\mathrm{T}$ transduzidos com as partículas lentivirais produzidas neste trabalho eram funcionais, foi realizada a modificação da linhagem celular CD4+ Jurkat e para checar a expressão do CAR em sua superfície e a efetividade do receptor em se ligar ao alvo CD19.

O primeiro passo foi determinar a quantidade ideal de vírus para transduzir nossas células alvo. Os ensaios de transdução foram realizados com duas concentrações virais:

a) 5 partículas lentivirais para 1 célula alvo ( $\mathrm{MOI} 5$ )

b) 10 partículas lentivirais para 1 célula alvo ( $\mathrm{MOI} 10$ ).

O cálculo do número de cópias integradas foi realizado por qPCR e a análise da expressão do CAR anti-CD19 foi feito por citometria de fluxo (Figura 15). Em média a MOI 5 apresentou 35,33 cópias integradas e a MOI 10, 42,63 cópias. 
Não houve diferença estatística no número de cópias virais integradas quando comparamos as infecções com MOI 5 e 10. Decidiu-se então que a transdução com MOI 5 seria a padrão para a realização dos experimentos posteriores.

Figura 15 - Cópias virais integradas

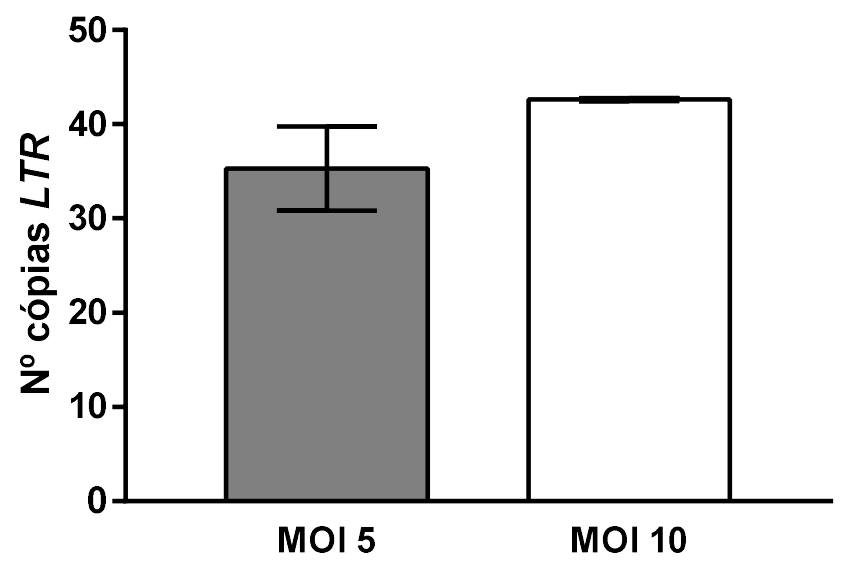

Cópias da sequência LTR viral integradas por genoma das células transduzidas utilizando-se MOI 5 e 10. Média \pm desvio padrão, $n=2$. Diferença não significativa (Teste $U$ de Mann-Whitney).

\subsubsection{Ensaio de ativação do CAR anti-CD19}

Para avaliarmos a efetividade do receptor CAR expresso na superfície das células Jurkat-CAR, foi feito o co-cultivo com a linhagem celular Sup-B15 (CD19+). A ativação de linfócitos $T$, in vitro e in vivo, induz a expressão de CD69 (Figura 16), que é uma glicoproteína envolvida na proliferação de linfócitos e funciona como um receptor transmissor de sinal em linfócitos. 
Figura 16 - Ativação das células CAR na presença do antígeno CD19

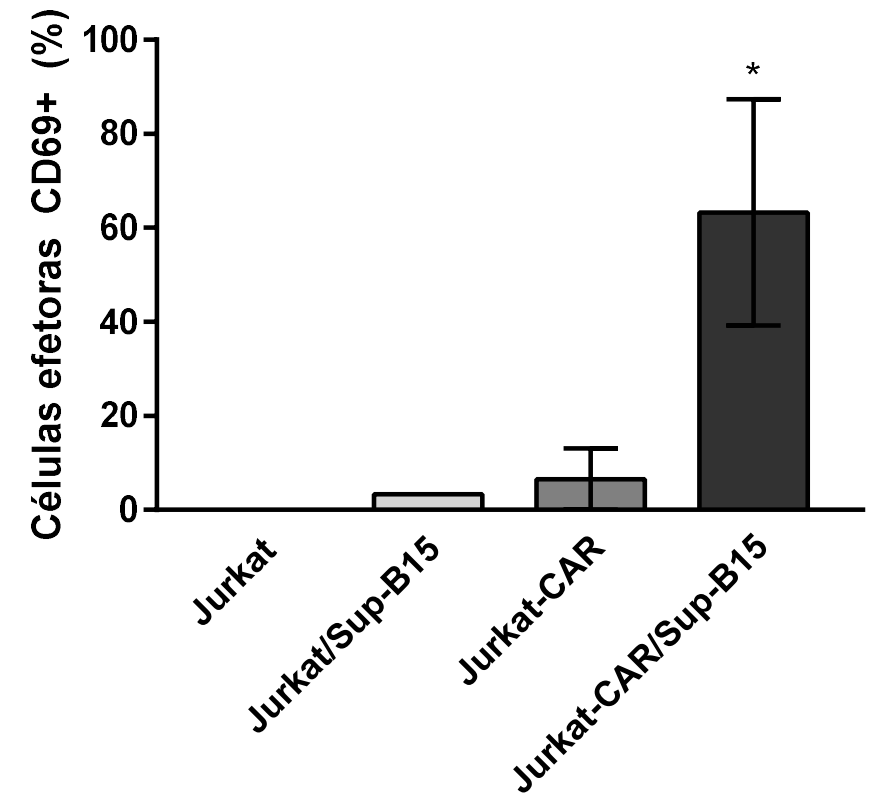

Porcentagem de células efetoras (Jurkat ou Jurkat-CAR) que expressam CD69 após co-cultivo com células $\mathrm{CD} 19^{+}$(Sup-B15). Média \pm desvio padrão, $n=2 .{ }^{*} \mathrm{P}<0,05$ (ANOVA seguida de Holm-Sidak).

As células Jurkat e as células Jurkat-CAR isoladas apresentam baixa ativação $\mathrm{CD}^{+} / \mathrm{CD} 9^{+}(0,05 \%$ e $6,52 \%$, respectivamente). As células Jurkat do co-cultivo com Sup-B15 também apresentam baixa ativação (3,39\%). Por outro lado, as células Jurkat-CAR provenientes do co-cultivo com Sup-B15 apresentam alta ativação $(63,29 \%)$, indicando o reconhecimento do CAR anti-CD19 com o antígeno CD19 presente na superfície das células Sup-B15.

\subsection{Ensaio funcional do CAR anti-CD19 em linfócitos T primários}

Uma vez determinado que os vetores lentivirais eram capazes de modificar a linhagem de linfócitos T (Jurkat) e que os receptores CAR expressos eram capazes de ativar a expressão de CD69, partimos para a modificação de linfócitos T primários obtidos do filtro de leucorredução do processo de doação de plaquetas por indivíduos saudáveis.

Os linfócitos $\mathrm{T}$ isolados foram ativados utilizando-se as beads magnéticas antiCD3/CD28 (1 bead por célula) e cultivados em RPMI 10\% soro humano AB suplementado com $100 \mathrm{UI} / \mathrm{mL}$ de IL-2. 
A transdução dos linfócitos T ativados foi realizada com MOI 5 em meio RPMI suplementado ou não com $10 \%$ de soro humano AB. Assim pudemos observar o efeito da presença de soro na eficiência de transdução das células. A expressão do receptor CAR foi observada por citometria de fluxo $72 \mathrm{~h}$ após a transdução e durante o cultivo e expansão dessas células (Tabela 7 e Figura 17).

Tabela 7 - Efeito do soro no meio de transdução na eficiência de modificação de linfócitos T primários.

Células $\mathrm{CAR}^{+}(\%)$

\begin{tabular}{lr}
\hline RPMI $\mathbf{1 0} \%$ soro $A B$ & $9,89 \pm 2,53$ \\
RPMI sem soro & $37,53 \pm 12,37$ \\
\hline \multicolumn{2}{l}{ Média \pm desvio padrão, $\mathrm{n}=3}$.
\end{tabular}

Figura 17 - Porcentagem de células $\mathrm{CAR}^{+}$ao longo da expansão

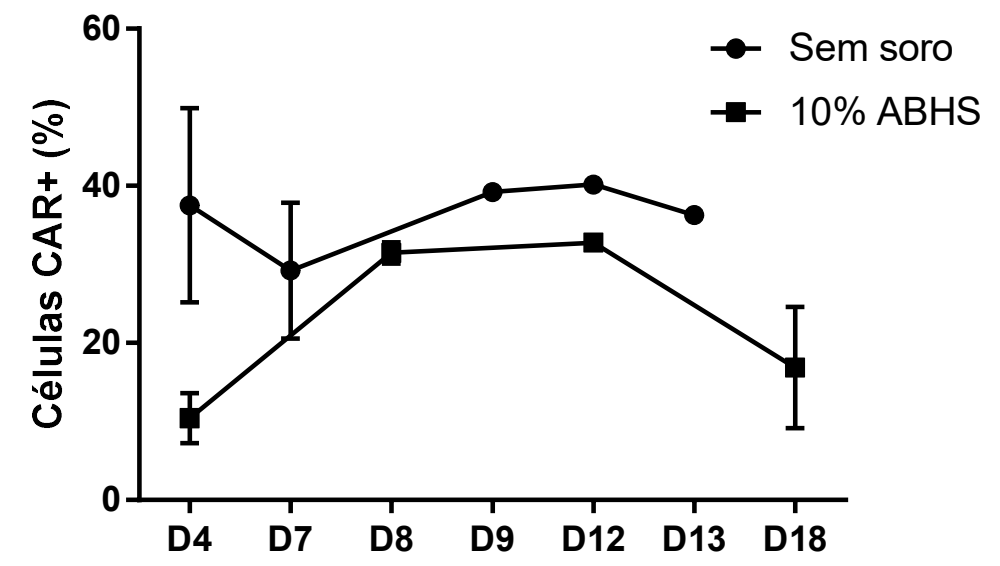

Porcentagem de células $\mathrm{CAR}^{+}$analisada por citometria de fluxo ao longo de 18 dias de expansão. Linfócitos $\mathrm{T}$ isolados no dia 0 (D0) e transduzidos no dia 1 (D1). Média \pm desvio padrão, $n=3$.

A transdução em meio sem soro resultou em maiores porcentagens de células modificadas que expressavam o receptor CAR em sua superfície, mantendo a expressão do CAR de forma estável durante o processo de expansão celular.

\subsubsection{Potencial citotóxico in vitro dos linfócitos T CAR}

A avaliação da funcionalidade dos receptores CAR expressos na superfície dos linfócitos T modificados foi realizada neste trabalho por duas metodologias: citometria de fluxo e por ensaio colorimétrico (LDH). Para avaliar a citotoxicidade, os linfócitos 
T-CAR foram cultivadas com células alvo CD19+. Como controle foram usados linfócitos $T$ sem modificação e a linhagem CD19- K562. A proporção 10:1 (efetoras:alvos) foi utilizada e a porcentagem de células alvo presentes no início e após $24 \mathrm{~h}$ de co-cultivo foi avaliada por citometria de fluxo (Figura 18). Em média, $31,32 \%$ dos linfócitos T-CAR expressavam CAR anti-CD19.

Figura 18 - Análise de citotoxicidade celular in vitro por citometria de fluxo
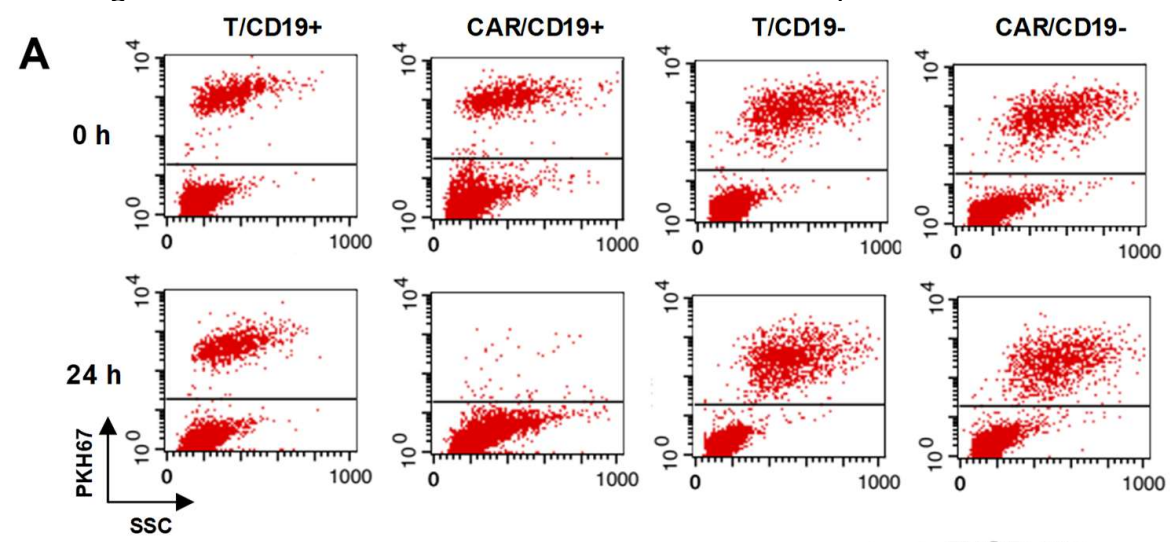

B
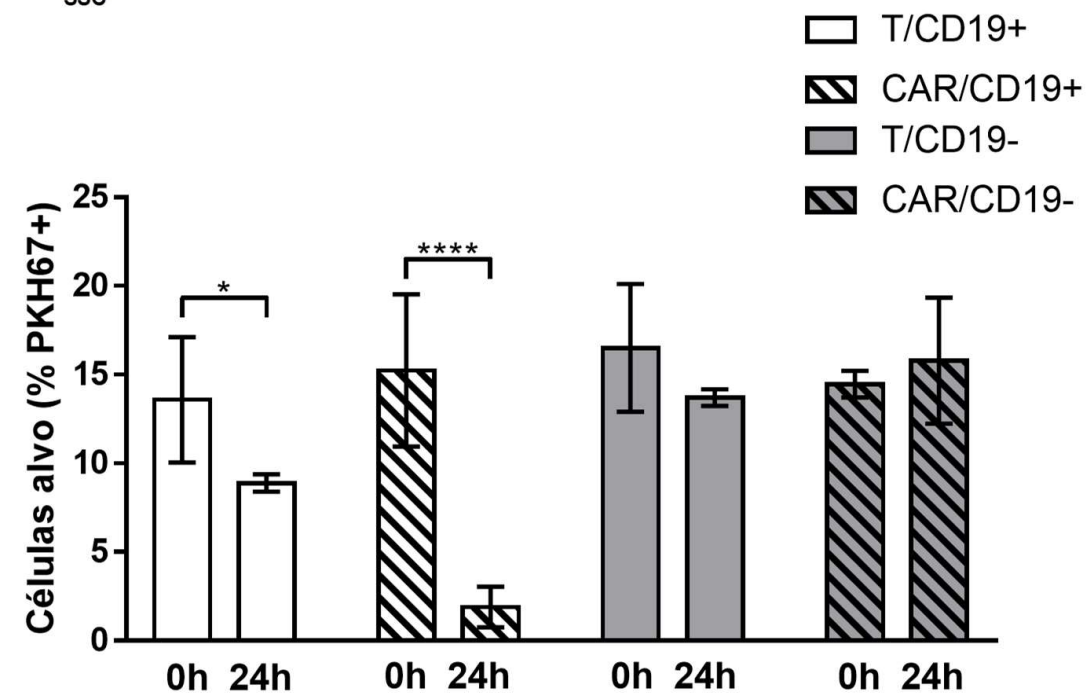

(A) Dot plots ilustrativos da análise dos co-cultivos ( 0 e $24 \mathrm{~h}$ ) por citometria de fluxo. Células efetoras: linfócitos T não transduzidos (T) e linfócitos T-CAR (CAR). Células alvo (PKH67+): Sup-B15 (CD19+) e K562 (CD19-). (B) Porcentagem de células alvo (PKH67+) no início e após 24 h de co-cultivo. Média \pm desvio padrão, $n=4 .{ }^{*} P<0,05,{ }^{* * * *} P<0,0001$ (ANOVA dois fatores seguida de Holm-Sidak).

Uma queda na porcentagem de células CD19+ após $24 \mathrm{~h}$ de co-cultivo tanto com os linfócitos T-CAR (redução de $87 \%$, de 15,24 para 1,91\%) como com os linfócitos T não modificados (de 13,59 para 8,89\%, não estatisticamente significante) foi observada. O mesmo não foi observado no co-cultivo de linfócito T-CAR com as 
células CD19-, mostrando a especificidade do receptor CAR em ser ativado apenas na presença do antígeno CD19. Houve uma pequena diminuição na quantidade de células CD19- após o co-cultivo com linfócitos T não modificados (de 16,51 para $13,71 \%)$.

O número ideal de 5000 células alvo para o co-cultivo e análise da citotoxicidade através da liberação de LDH foi determinado por espectrofotometria. Foram realizados então ensaios de co-cultivo no qual foi analisada a liberação de LDH. Linfócitos T-CAR (aproximadamente $23,60 \% \mathrm{CAR}^{+}$) e linfócitos não transduzidos foram incubados com células $\operatorname{CD19}^{+}$e CD19- nas proporções de 1:1 e 5:1 (efetoras:alvos). A porcentagem de citotoxicidade nos co-cultivos estão expressos na Figura 19.

Figura 19 - Análise de citotoxicidade in vitro por espectrofotometria

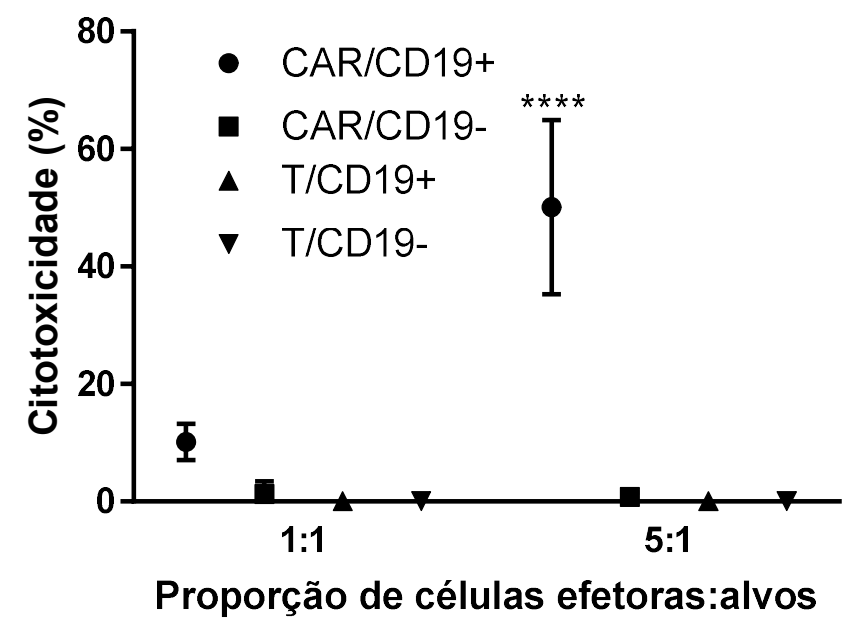

Porcentagem de citotoxicidade calculada através da absorbância do LDH liberado nos co-cultivos nas proporções 1:1 e 5:1 (efetoras:alvos). Células efetoras: linfócitos T não transduzidos (T) e linfócitos TCAR (CAR). Células alvo Sup-B15 (CD19+) e K562 (CD19-). Média \pm desvio padrão, $n=3$. ${ }^{* * * *} \mathrm{P}<$ 0,0001 (ANOVA dois fatores seguida de Holm-Sidak).

Como esperado, foram observadas elevadas porcentagens médias de citotoxicidade no co-cultivo com células CD19+ para as duas proporções de células utilizadas (10,13 e 50,08\%, para 1:1 e 5:1, respectivamente). Do mesmo modo, não observamos citotoxicidade nos co-cultivos com células CD19-, mostrando a especificidade dos nossos linfócitos T-CAR (1,25 e 0,75\%, para 1:1 e 5:1, respectivamente). Não foi observada citotoxicidade nos co-cultivos com linfócitos $T$ não transduzidos para nenhuma das duas proporções de células utilizadas. 
Discussão 


\section{DISCUSSÃO}

Linfócitos T-CAR combinam a especificidade de um anticorpo monoclonal com a resposta mediada por linfócitos $T$, resultando na sua expansão, persistência, morte de células tumorais e indução de memória imunológica (LITTMAN; HEXNER, 2017). A criação de diversos CARs com diferentes domínios extra e intracelulares possibilitou a realização de ensaios clínicos contra variados tipos tumorais. Em 2017 o FDA (Food and Drug Administration), agência federal dos Estados Unidos responsável pela proteção e promoção da saúde pública, aprovou a primeira terapia baseada em linfócitos T-CAR anti-CD19 modificados com vetores lentivirais, o tisagenlecleucel $\left(K_{y m r i a h}{ }^{\circledast}\right)$. Esta terapia foi aprovada para o tratamento de pacientes jovens com leucemia linfoide aguda (LLA) (U.S. FOOD AND DRUG ADMINISTRATION, 2017a) e, em 2018, para o tratamento de adultos com linfoma difuso de grandes células $B$ (LDGCB) (U.S. FOOD AND DRUG ADMINISTRATION, 2018). Também em 2017, um segundo produto foi aprovado para o tratamento de LDGCB, axicabtagene ciloleucel (Yescarta ${ }^{\mathrm{TM}}$ ), que é baseada na modificação com vetores retrovirais (U.S. FOOD AND DRUG ADMINISTRATION, 2017b).

Neste trabalho nós realizamos a produção de linfócitos T-CAR de segunda geração. O vetor por nós utilizado possui o domínio extracelular anti-CD19, o domínio transmembrana derivado do CD8 e o 4-1BB como domínio de co-estimulação. Além do estímulo causado pela ligação do CAR ao antígeno alvo, a célula também pode ser estimulada por sinais tônicos antígeno-independentes. $O$ domínio de co-estimulação 4-1BB promove um aumento na persistência dos linfócitos T CAR, enquanto diminui a exaustão induzida pela sinalização tônica antígeno-independente do CAR, quando comparado com CD28 (LONG et al., 2015). No entanto, este sinal tônico também está presente nos construtos que utilizam a co-estimulação com 4-1BB, podendo causar apoptose e impedir a atividade antitumoral (GOMES-SILVA et al., 2017). O domínio transmembrana pode ser derivado do TCR ou de outras proteínas transmembranas como CD8, CD4 ou CD28 e está relacionado à estabilidade do CAR. A inclusão do domínio transmembrana derivado do CD28 leva à expressão mais estável do CAR

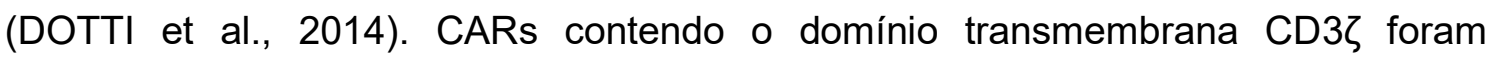
incorporados ao TCR endógeno da célula, resultando no aumento da ativação do linfócito T (BRIDGEMAN et al., 2010). Não existem dados na literatura quanto à 
estabilidade do domínio transmembrana CD8 por nós utilizado.

Vetores lentivirais são os mais utilizados nos ensaios clínicos com linfócitos TCAR. Eles são considerados mais seguros que os y-retrovírus por resultarem em uma menor mutagênese insercional (MCGARRITY et al., 2013; MONTINI et al., 2006, 2009; NESCHADIM et al., 2007). Outro método de transferência gênica utilizado em ensaios clínicos, mas que necessitou de diversas infusões de linfócitos T-CAR, é a transfecção do RNA mensageiro que será traduzido no CAR (BEATTY et al., 2014). Uma metodologia considerada de custo baixo e que foi testada em ensaios clínicos é a utilização de transposons Sleeping Beauty (HULS et al., 2013; SINGH et al., 2013). No entanto, existem preocupações quanto a sua segurança, pelo potencial de mutagênese insercional e remobilização de transposons, e quanto à sua eficácia quando comparada aos vetores lentivirais (ARONOVICH; MCIVOR; HACKETT, 2011).

Conforme verificado pela digestão com enzimas de restrição (Figura 7), os vetores plasmidiais clonados e expandidos nas bactérias $E$. coli Stb/3 se encontravam íntegros e puderam ser utilizados para a produção de partículas lentivirais. A geração de estoques de partículas lentivirais com títulos altos $\left(10^{7} \mathrm{TU} / \mathrm{mL}\right)$ para uso terapêutico desses vetores é possível apenas com a concentração do sobrenadante viral (YACOUB et al., 2007). Durante as primeiras produções lentivirais não concentradas, obtivemos título viral muito aquém do necessário (1,65 × 105 TU/mL). Seria necessário otimizar a produção lentiviral e realizar a concentração das partículas produzidas.

O primeiro passo para essa otimização foi a definição de qual método de titulação seria utilizado. Os métodos de titulação existentes podem ser divididos em funcionais e não-funcionais. Os métodos não-funcionais incluem ELISA do antígeno p24 e determinação do RNA genômico viral por northern blot semi-quantitativo. Contudo, estes métodos não distinguem partículas virais funcionais das partícula virais totais (GERAERTS et al., 2006). Nós realizamos a comparação entre dois métodos funcionais de titulação: a qPCR do DNA pró-viral e a citometria de fluxo para detecção do transgene expresso. O título funcional é o número de partículas virais necessários para se infectar uma célula em um dado volume. A célula escolhida para titulação foi a linhagem celular Jurkat por representar de maneira mais realista a infecção de linfócitos T primários, quando comparado com a célula HEK293T que é facilmente transduzida (PICANÇO-CASTRO et al., 2008). Assim como observado por 
Sastry et al. (2002), quando comparamos os métodos de titulação (Figura 8), o título obtido por qPCR foi aproximadamente 10 vezes maior que o obtido por citometria de fluxo. Técnicas de qPCR tendem a superestimar o título funcional. Isso acontece pois pode haver múltipla integração do transgene, além da amplificação de DNA plasmidial proveniente do meio contendo as partículas lentivirais. Além disso, a expressão do transgene pode variar devido ao local de integração do DNA pró-viral no genoma da célula (GERAERTS et al., 2006).

A análise por citometria de fluxo, por outro lado, nos mostra a expressão do transgene, que normalmente está associada a um gene repórter como o eGFP. Como nosso construto CAR não possuía nenhum gene repórter, se fez necessário a marcação do receptor expresso na superfície das células. Para tal utilizamos o anticorpo anti-F(ab')2 conjugado com Alexa Fluor ${ }^{\circledR} 647$ (KOCHENDERFER et al., 2012) ou a proteína L (ZHENG; CHINNASAMY; MORGAN, 2012). A análise por citometria de fluxo não discrimina células com integrações únicas ou múltiplas (GERAERTS et al., 2006). Para contornarmos este problema foram utilizadas para os cálculos apenas amostras contendo de 5 a $20 \%$ de células $\mathrm{CAR}^{+}$, pois valores maiores podem mascarar múltiplas integrações.

Vetores retrovirais não são estáveis a $37^{\circ} \mathrm{C}$, isso significa que é necessário se coletar o sobrenadante viral produzido pelo menos uma vez por dia e armazenado sob refrigeração e posteriormente à $-80^{\circ} \mathrm{C}$ (MERTEN, 2004). Segundo Merten et al. (2014), o sobrenadante pode ser coletado diversas vezes por dia por diversos dias. No entanto, decidimos realizar apenas uma coleta por dia por 2 dias consecutivos (Figura 9) obtendo um título médio de 2,47 × $10^{7} \mathrm{TU} / \mathrm{mL}$ após concentração por ultracentrifugação.

Uma vez determinado o número de coletas a serem realizadas, nós avaliamos o efeito da proporção entre os plasmídeos utilizados (pCAR:pHelp1:pHelp2:pHelp3). Protocolos sugerem o uso da proporção 4:2,6:1,4:1 (MERTEN et al., 2011; TISCORNIA; SINGER; VERMA, 2006), ou similar, 4:2:1:1 (CRIBBS et al., 2013). A utilização desta primeira proporção não resultou em aumento significante do título viral obtido, em comparação com a proporção $3: 1: 1: 1$, indicada pelo fornecedor dos plasmídeos (Figura 10). 
A produção dos vetores lentivirais pode ser aumentada utilizando-se butirato de sódio (MERTEN; HEBBEN; BOVOLENTA, 2016). Assim como a tricostatina A, o ácido valproico, e outros inibidores da histona deacetilase, o $\mathrm{NaBu}$ previne a compactação do DNA, facilitando a transcrição do RNA e aumentado a produção das partículas virais (JAALOUK et al., 2006; KAROLEWSKI et al., 2003). Diversos trabalhos já relataram o aumento da produção de partículas lentivirais ao se adicionar $\mathrm{NaBu}$ a uma concentração final 2 a 20 mM (ANSORGE et al., 2009; CARON et al., 2015; MERTEN, 2004; SAKODA et al., 1999; SENA-ESTEVES et al., 2004). Em nossos testes, a adição de $5 \mathrm{mM}$ de $\mathrm{NaBu}$ no momento da transfecção com PEI mais que triplicou o título viral obtido (Figura 11). Um aumento de quase 2 vezes foi observado quando $5 \mathrm{mM}$ de $\mathrm{NaBu}$ foi adicionado à transfecção com Lipodefctamine ${ }^{\circledR}$ 2000 (Figura 12). Em comparação com o protocolo original (PEI), nossa otimização (Lipodefctamine ${ }^{\circledR}+\mathrm{NaBu}$ ) resultou em um aumento de aproximadamente 17 vezes no título viral.

O polímero catiônico linear de 25 kDa, PEl, e o fosfato de cálcio são os métodos de transfecção mais utilizados para produção de vetores virais para estudos clínicos (MERTEN et al., 2014). O PEI se destaca por ter um melhor custo-benefício quando comparado com lipídios catiônicos, com a Lipofectamine ${ }^{\circledR} 2000$, além de ser mais robusto que o fosfato de cálcio, por ser menos sensível a solutos dissolvidos e a alterações no pH (WRIGHT, 2009). Uma desvantagem da utilização do PEI é que não existem métodos de se analisar a presença do polímero com os vetores produzidos. Ainda não se sabe se o PEl está presente com o vetor purificado e se a molécula pode causar algum prejuízo para a estabilidade e capacidade de infecção do vírus (MERTEN; HEBBEN; BOVOLENTA, 2016).

A ultracentrifugação é o método mais comum de se concentrar vetores lentivirais pseudotipados com VSV-G. Este método, no entanto, possui algumas desvantagens: necessidade de acesso a uma ultracentrífuga; é um processo demorado; e a manutenção e materiais utilizados são caros (PAPANIKOLAOU et al., 2013). Na primeira vez que esse método foi descrito, Burns et al. (1993) relataram uma taxa de recuperação das partículas virais de 96\%. Contudo, a taxa de recuperação cai ao se concentrar lentivírus contendo grandes insertos (YACOUB et al., 2007), o que pode explicar a nossa taxa de recuperação de apenas 53,91\% (Figura 
13). Taxas de recuperação semelhantes às obtidas em nosso estudo já haviam sido reportadas (KOWOLIK; YEE, 2002; SENA-ESTEVES et al., 2004).

A ultrafiltração tangencial é considerada um processo eficiente para concentração de grandes volumes de sobrenadante em pouco tempo (SCHWEIZER; MERTEN, 2010). Altas taxas de recuperação (>90\%) podem ser obtidas utilizando-se essa metodologia, seja empregando-se apenas a filtração tangencial (COOPER et al., 2011) ou associando ela à ultracentrifugação (GERAERTS et al., 2005). Nos nossos testes, no entanto a recuperação das partículas lentivirais não ultrapassou $61 \%$ (Tabela 3, Tabela 4 e Tabela 5) utilizando-se apenas a filtração tangencial. A perda de quase $25 \%$ das partículas lentivirais observada no terceiro teste com o QuixStand ${ }^{\circledR}$ (Tabela 5), poderia ser explicada por um dano sofrido pela membrana, o que permitiu que os vetores virais fossem eliminados no permeado. Os volumes pós-filtração ainda eram grandes e com baixo título (ordem de $10^{5} \mathrm{TU} / \mathrm{mL}$ ), fazendo-se necessária uma segunda etapa de concentração por ultracentrifugação. Aliando-se as duas metodologias, a nossa taxa de recuperação não passou 26\% (Tabela 6), valor muito similar ao reportado por Koldej et al. (2005). Seria interessante a realização de outros experimentos para averiguar o rendimento de concentração por filtração tangencial, pois este método poderia ser facilmente empregado em produções em larga escala por se tratar de uma tecnologia considerada escalonável (SCHWEIZER; MERTEN, 2010).

A terceira metodologia por nós avaliada foi a ultrafiltração sobre membrana, desenvolvida por Reiser (2000) ao utilizar unidades de Centricon ${ }^{\circledR}$ Plus-80 com corte de peso molecular de 100 kDa. Utilizando uma unidade com o mesmo MWCO, SenaEsteves et al. (2004) obtiveram taxas de recuperação melhores do que utilizando ultracentrifugação. Nós fizemos uso de unidades de VivaSpin ${ }^{\circledR} 20$ de 100 kDa e obtivemos uma taxa de recuperação de $81,80 \%$ (Figura 14). Taxa de $67 \pm 6 \%$ foi descrita por Bandeira et al. (2012) utilizando-se esta mesma unidade. Coleman et al. (2003) combinaram as técnicas de ultrafiltração sobre membrana e ultracentrifugação obtendo uma recuperação aproximada de $84 \%$. Uma desvantagem desta metodologia é o fato de também serem concentradas as proteínas do soro presentes no meio de produção (REISER, 2000), o que pode impactar na transdução (Tabela 7). O ideal seria a utilização de meio sem soro para a produção as partículas virais. 
Realizamos a transdução da linhagem Jurkat com MOI 5 utilizando os vetores lentivirais produzidos e para verificar a efetividade dos receptores CAR expressos foi feito o co-cultivo dessas células com células as CD19+ Sup-B15. Assim como relatado por Duong et al. (2013), observamos a expressão do marcador de ativação CD69 na células Jurkat-CAR incubadas com Sup-B15 (Figura 16). Esse resultado nos mostrou que os receptores CAR eram funcionais e capazes de reconhecer o antígeno CD19. O próximo passo seria a verificar a efetividade do CAR em linfócitos T citotóxicos.

Linfócitos T do sangue periférico não se encontram com o ciclo celular ativo e necessitam de ativação para que a transdução lentiviral seja eficiente (VERHOEYEN; COSTA; COSSET, 2009; ZACK; KIM; VATAKIS, 2013). A ativação com beads magnéticas anti-CD3/anti-CD28 promove uma ativação eficiente de linfócitos $\mathrm{T}$ in vitro. Sua ativação é mais eficiente do que o uso de células apresentadoras de antígenos, tais como as células dendríticas, e anticorpos solúveis como OKT3 (LEVINE et al., 2017; TRICKETT; KWAN; LAM KWAN, 2003).

Neste trabalho, a ativação dos linfócitos foi realizada com beads anti-CD3/antiCD28 na proporção 1:1 (células:beads) e presença de $100 \mathrm{UI} / \mathrm{mL}$ de IL-2. Segundo Cavalieri et al. (2003), o pré-estímulo das células com IL-2 ou IL-7 pode melhorar a eficiência da transdução lentiviral. A análise de ativação foi feita por citometria de fluxo através da análise da expressão dos marcadores de ativação CD25 e CD69 (TRICKETT; KWAN; LAM KWAN, 2003). Após 24 horas realizou-se a transdução com os vetores lentivirais, assim como descrito na literatura (KENNEDY; CRIBBS, 2016; MOCK et al., 2016). Durante a transdução foi utilizado o método de spinoculation (infecção por centrifugação) (ANASTASOV et al., 2016; ZHANG et al., 2010), pois desse modo a adsorção dos vírions é estimulada pelo seu depósito na superfície das células alvo (O'DOHERTY; SWIGGARD; MALIM, 2000).

O tipo de soro presente no meio de transdução afeta a eficiência da modificação por lentivírus, devendo ser testado para otimizar a transdução (DENNING et al., 2013). Assim, analisamos o efeito do soro na transdução ao realizarmos transduções em meio RPMI suplementado ou não com 10\% de AB. Diferente do relatado por Uchida et al. (2011) na transdução de células CD34 ${ }^{+}$, a presença de soro diminuiu a eficiência de transdução dos linfócitos T (Tabela 7). 
A análise da citotoxicidade dos linfócitos T-CAR anti-CD19 produzidos foi realizada através de co-cultivo com células $\mathrm{CD}_{19}{ }^{+}$. A lise específica foi observada tanto por citometria de fluxo (Figura 18) quanto por espectrofotometria da liberação de LDH (Figura 19). Assim como descrito na literatura (KOCHENDERFER et al., 2009; MAHER et al., 2002; REN et al., 2015), nossos linfócitos T-CAR se mostraram específicos contra células que expressavam a molécula alvo em sua superfície.

A maior preocupação do uso de CARs em tratamentos é o risco de toxicidade para tecidos que possuem o antígeno alvo, mas que não são tumores. Na terapia com linfócitos T-CAR específicos contra CD19 é esperado a ocorrência de aplasia de linfócitos B (BRENTJENS et al., 2011; KALOS et al., 2011; KOCHENDERFER et al., 2012) e isto serve de marcador farmacodinâmico da funcionalidade deste tratamento. Felizmente, a infusão de gama globulinas pode ser usada como tratamento da aplasia de linfócitos B (DAl et al., 2016).

A segunda maior preocupação em relação à terapia com linfócitos T-CAR é a síndrome da liberação de citocinas (CRS), devido ao grande número de linfócitos ativados. Esta síndrome está relacionada com a produção de diversas citocinas proinflamatórias, como IL-6, TNFa e IFNy, e há manifestação de febre alta, hipotensão e hipóxia (DAl et al., 2016). Um modo de se diminuir os efeitos de toxicidade é desenvolver um CAR com genes de suicídio, que seriam ativados caso um quadro se toxicidade aguda fosse apresentado, levando à eliminação dos linfócitos (DI STASI et al., 2011). Recentemente pesquisadores têm desenvolvido linfócitos T-CAR dependentes de adaptadores. Neste caso, o linfócito T-CAR não possui especificidade contra o tecido humano, e sim contra uma pequena molécula peptídica. O adaptador é esta molécula peptídica ligada a um anticorpo contra um antígeno tumoral. O linfócito T-CAR só será ativado na presença deste adaptador, acarretando menores níveis de citocinas, diminuindo a CRS (RODGERS et al., 2016). Outra alternativa para mitigar a toxicidade inespecífica dos linfócitos T-CAR é a separação do receptor CAR em dois heterodímeros, que somente se tornam funcionais na presença de uma pequena molécula capaz de agregá-los. Esta estratégia permite o controle do tempo, da localização e da dosagem da atividade citotóxica (WU et al., 2015).

Em suma, este trabalho contribuiu para o estabelecimento de uma metodologia para produção de vetores lentivirais, em grande quantidade, e capazes de realizar a 
modificação de linfócitos T com receptor quimérico anti-CD19. Os próximos passos envolvem a produção destes vetores lentivirais seguindo-se as Boas Práticas de Fabricação, para que possam ser utilizados posteriormente em ensaios clínicos. 
Conclusão 


\section{CONCLUSÃo}

Este trabalho desenvolveu uma plataforma de produção de vetores lentivirais CAR anti-CD19 em quantidade suficiente para transduzir células de pacientes.

$\checkmark$ A coleta do sobrenadante viral 24 e outra 48 horas após a transfecção resultou nos maiores títulos virais;

$\checkmark$ A produção de partículas virais utilizando plasmídeos na proporção 3:1:1:1, lipossomo catiônico e butirato de sódio produziu os títulos virais mais altos;

$\checkmark$ A ultrafiltração sobre membrana de polietersulfona com MWCO de 100 kDa resultou na maior taxa de recuperação de partículas virais viáveis;

$\checkmark$ As partículas virais produzidas se mostraram funcionais para a modificação de linfócitos $\mathrm{T}$;

$\checkmark$ O receptor CAR se mostrou específico contra células CD19+, ativando o linfócito T-CAR e gerando citotoxicidade contra as células alvo, em ensaios in vitro. 


\section{Referências}

bibliográficas 


\section{REFERÊNCIAS BIBLIOGRÁFICAS'1}

ANASTASOV, N. et al. Optimized Lentiviral Transduction Protocols by Use of a Poloxamer Enhancer, Spinoculation, and scFv-Antibody Fusions to VSV-G. In: FEDERICO, M. (Ed.). . Methods in Molecular Biology. New York, NY: Humana Press, 2016. v. 1448p. 49-61.

ANSORGE, S. et al. Development of a scalable process for high-yield lentiviral vector production by transient transfection of HEK293 suspension cultures. The Journal of Gene Medicine, v. 11, n. 10, p. 868-876, out. 2009.

ARONOVICH, E. L.; MCIVOR, R. S.; HACKETT, P. B. The Sleeping Beauty transposon system: a non-viral vector for gene therapy. Human Molecular Genetics, v. 20, n. R1, p. R14-R20, 15 abr. 2011.

BALDI, L. et al. Transient Gene Expression in Suspension HEK-293 Cells: Application to Large-Scale Protein Production. Biotechnology Progress, v. 21, n. 1, p. $148-153,5$ set. 2008.

BANDEIRA, V. et al. Downstream Processing of Lentiviral Vectors: Releasing Bottlenecks. Human Gene Therapy Methods, v. 23, n. 4, p. 255-263, 30 ago. 2012.

BARRETT, D. M. et al. Chimeric Antigen Receptor Therapy for Cancer. Annual Review of Medicine, v. 65, n. 1, p. 333-347, 14 jan. 2014.

BEATTY, G. L. et al. Mesothelin-Specific Chimeric Antigen Receptor mRNAEngineered $\mathrm{T}$ Cells Induce Antitumor Activity in Solid Malignancies. Cancer Immunology Research, v. 2, n. 2, p. 112-120, 1 fev. 2014.

BOULASSEL, M. R.; GALAL, A. Immunotherapy for B-cell neoplasms using T cells expressing chimeric antigen receptors from antigen choice to clinical implementation. Sultan Qaboos University Medical Journal, v. 12, n. 3, p. 273-285, 2012.

BOUSSIF, O. et al. A versatile vector for gene and oligonucleotide transfer into cells in culture and in vivo: polyethylenimine. Proceedings of the National Academy of Sciences of the United States of America, v. 92, n. 16, p. 7297-301, 1 ago. 1995.

BRENTJENS, R. J. et al. Genetically targeted T cells eradicate systemic acute lymphoblastic leukemia xenografts. Clinical Cancer Research, v. 13, n. 18, p. 54265435, 15 set. 2007.

BRENTJENS, R. J. et al. Safety and persistence of adoptively transferred autologous CD19-targeted T cells in patients with relapsed or chemotherapy refractory B-cell leukemias. Blood, v. 118, n. 18, p. 4817-4828, 3 nov. 2011.

BRENTJENS, R. J. et al. CD19-Targeted T Cells Rapidly Induce Molecular Remissions in Adults with Chemotherapy-Refractory Acute Lymphoblastic Leukemia. Science Translational Medicine, v. 5, n. 177, p. 177ra38-177ra38, 20 mar. 2013.

\footnotetext{
1 De acordo com a Associação Brasileira de Normas Técnicas (ABNT NBR 6023).
} 
BRIDGEMAN, J. S. et al. The Optimal Antigen Response of Chimeric Antigen Receptors Harboring the CD3 Transmembrane Domain Is Dependent upon Incorporation of the Receptor into the Endogenous TCR/CD3 Complex. The Journal of Immunology, v. 184, n. 12, p. 6938-6949, 15 jun. 2010.

BROWN, J. R.; PORTER, D. L.; O'BRIEN, S. M. Novel Treatments for Chronic Lymphocytic Leukemia and Moving Forward. American Society of Clinical Oncology Educational Book, v. 34, p. e317-e325, 2014.

BURNS, J. C. et al. Vesicular stomatitis virus G glycoprotein pseudotyped retroviral vectors: Concentration to very high titer and efficient gene transfer into mammalian and nonmammalian cells. Genetics, v. 90, p. 8033-8037, 1993.

CARON, A. L. et al. Production of Lentiviral Vectors Encoding Recombinant Factor VIII Expression in Serum-Free Suspension Cultures. Brazilian Archives of Biology and Technology, v. 58, n. 6, p. 923-928, dez. 2015.

CAVALIERI, S. et al. Human T lymphocytes transduced by lentiviral vectors in the absence of TCR activation maintain an intact immune competence. Blood, v. 102, n. 2, p. 497-505, 13 mar. 2003.

COLEMAN, J. E. et al. Efficient large-scale production and concentration of HIV1-based lentiviral vectors for use in vivo. Physiological Genomics, v. 12, n. 3, p. 221228, 6 fev. 2003.

COOPER, A. R. et al. Highly efficient large-scale lentiviral vector concentration by tandem tangential flow filtration. Journal of Virological Methods, v. 177, n. 1, p. $1-9$, out. 2011.

COUZIN-FRANKEL, J. Cancer Immunotherapy. Science, v. 342, n. 6165, p. 1432-1433, 20 dez. 2013.

CRIBBS, A. P. et al. Simplified production and concentration of lentiviral vectors to achieve high transduction in primary human T cells. BMC Biotechnology, v. 13, n. 1, p. 98, 2013.

DAI, H. et al. Chimeric Antigen Receptors Modified T-Cells for Cancer Therapy. Journal of the National Cancer Institute, v. 108, n. 7, p. 1-15, 2016.

DALBY, B. Advanced transfection with Lipofectamine 2000 reagent: primary neurons, siRNA, and high-throughput applications. Methods, v. 33, n. 2, p. 95-103, 1 jun. 2004.

DAVILA, M. L. et al. Efficacy and Toxicity Management of 19-28z CAR T Cell Therapy in B Cell Acute Lymphoblastic Leukemia. Science Translational Medicine, v. 6, n. 224, p. 224ra25-224ra25, 19 fev. 2014.

DENNING, W. et al. Optimization of the Transductional Efficiency of Lentiviral Vectors: Effect of Sera and Polycations. Molecular Biotechnology, v. 53, n. 3, p. 308314, 11 mar. 2013.

DI STASI, A. et al. Inducible Apoptosis as a Safety Switch for Adoptive Cell 
Therapy. New England Journal of Medicine, v. 365, n. 18, p. 1673-1683, 3 nov. 2011.

DONG, W. et al. Efficient gene transfection into mammalian cells mediated by cross-linked polyethylenimine. International Journal of Molecular Sciences, v. 8, n. 2, p. 81-102, 14 fev. 2007.

DOTTI, G. et al. Design and development of therapies using chimeric antigen receptor-expressing T cells. Immunological Reviews, v. 257, n. 1, p. 107-126, jan. 2014.

DUBRIDGE, R. B. et al. Analysis of mutation in human cells by using an EpsteinBarr virus shuttle system. Molecular and Cellular Biology, v. 7, n. 1, p. 379-87, jan. 1987.

DULL, T. et al. A third-generation lentivirus vector with a conditional packaging system. Journal of Virology, v. 72, n. 11, p. 8463-71, nov. 1998.

DUONG, C. P. M. et al. Engineering T Cell Function Using Chimeric Antigen Receptors Identified Using a DNA Library Approach. PLoS ONE, v. 8, n. 5, p. e63037, 7 maio 2013.

ESCORS, D.; BRECKPOT, K. Lentiviral Vectors in Gene Therapy: Their Current Status and Future Potential. Archivum Immunologiae et Therapiae Experimentalis, v. 58, n. 2, p. 107-119, 9 abr. 2010.

ESHHAR, Z. et al. Specific activation and targeting of cytotoxic lymphocytes through chimeric single chains consisting of antibody-binding domains and the $y$ or $C$ subunits of the immunoglobulin and T-cell receptors. Immunology, v. 90, p. 720-724, 1993.

ESHHAR, Z. et al. Functional expression of chimeric receptor genes in human T cells. Journal of Immunological Methods, v. 248, n. 1-2, p. 67-76, fev. 2001.

FELGNER, P. L. et al. Lipofection: a highly efficient, lipid-mediated DNAtransfection procedure. Proceedings of the National Academy of Sciences of the United States of America, v. 84, n. 21, p. 7413-7, nov. 1987.

FERLAY, J. et al. Cancer incidence and mortality worldwide: Sources, methods and major patterns in GLOBOCAN 2012. International Journal of Cancer, v. 136, n. 5, p. E359-E386, 1 mar. 2015.

FINNEY, H. M. et al. Chimeric receptors providing both primary and costimulatory signaling in $\mathrm{T}$ cells from a single gene product. Journal of Imunology, v. 161 , n. 6 , p. $2791-2797,15$ set. 1998.

FLEMMING, A. Cancer: PD1 makes waves in anticancer immunotherapy. Nature Reviews Drug Discovery, v. 11, n. 8, p. 601-601, 1 ago. 2012.

GAMA-NORTON, L. et al. Lentivirus Production Is Influenced by SV40 Large TAntigen and Chromosomal Integration of the Vector in HEK293 Cells. Human Gene Therapy, v. 22, n. 10, p. 1269-1279, out. 2011. 
GARFALL, A. L. et al. Chimeric Antigen Receptor T Cells against CD19 for Multiple Myeloma. New England Journal of Medicine, v. 373, n. 11, p. 1040-1047, 10 set. 2015.

GERAERTS, M. et al. Upscaling of lentiviral vector production by tangential flow filtration. The Journal of Gene Medicine, v. 7, n. 10, p. 1299-1310, out. 2005.

GERAERTS, M. et al. Comparison of lentiviral vector titration methods. BMC Biotechnology, v. 6, n. 1, p. 34, 2006.

GOKER, H.; HAZNEDAROGLU, I. C.; CHAO, N. J. Acute graft-vs-host disease: Pathobiology and management. Experimental Hematology, v. 29, n. 3, p. 259-277, mar. 2001.

GOMES-SILVA, D. et al. Tonic 4-1BB Costimulation in Chimeric Antigen Receptors Impedes T Cell Survival and Is Vector-Dependent. Cell Reports, v. 21, n. 1, p. 17-26, out. 2017.

GOPALKRISHNAN, R. V et al. Use of the human EF-1alpha promoter for expression can significantly increase success in establishing stable cell lines with consistent expression: a study using the tetracycline-inducible system in human cancer cells. Nucleic Acids Research, v. 27, n. 24, p. 4775-82, 15 dez. 1999.

GRAESSMANN, M. et al. Helper activity for gene expression, a novel function of the SV40 enhancer. Nucleic Acids Research, v. 17, n. 16, p. 6603-12, 25 ago. 1989.

GROSS, G.; WAKS, T.; ESHHAR, Z. Expression of immunoglobulin-T-cell receptor chimeric molecules as functional receptors with antibody-type specificity. Proceedings of the National Academy of Sciences of the United States of America, v. 86, n. 24, p. 10024-10028, 1989.

HANAHAN, D. Studies on transformation of Escherichia coli with plasmids. Journal of Molecular Biology, v. 166, n. 4, p. 557-80, 5 jun. 1983.

HODI, F. S. et al. Improved Survival with Ipilimumab in Patients with Metastatic Melanoma. New England Journal of Medicine, v. 363, n. 8, p. 711-723, 19 ago. 2010.

HULS, M. H. et al. Clinical Application of <em>Sleeping Beauty</em> and Artificial Antigen Presenting Cells to Genetically Modify T Cells from Peripheral and Umbilical Cord Blood. Journal of Visualized Experiments, n. 72, p. e50070, 1 fev. 2013.

INSTITUTO NACIONAL DE CÂNCER JOSÉ ALENCAR GOMES DA SILVA. Estimativa 2018: Incidência de câncer no Brasil. Rio de Janeiro: [s.n.].

JAALOUK, D. E. et al. Inhibition of histone deacetylation in 293GPG packaging cell line improves the production of self-inactivating MLV-derived retroviral vectors. Virology Journal, v. 3, n. 1, p. 27, 7 abr. 2006.

JENSEN, M. C. et al. Human T Lymphocyte Genetic Modification with Naked 
DNA. Molecular Therapy, v. 1, n. 1, p. 49-55, jan. 2000.

JUNE, C. H. C. Adoptive T cell therapy for cancer in the clinic. Journal of Clinical Investigation, v. 117, n. 6, p. 1466-1476, 1 jun. 2007.

KALOS, M. et al. T Cells with Chimeric Antigen Receptors Have Potent Antitumor Effects and Can Establish Memory in Patients with Advanced Leukemia. Science Translational Medicine, v. 3, n. 95, p. 95ra73-95ra73, 10 ago. 2011.

KALOS, M. et al. Chimeric Antigen Receptor Modified T Cells Directed Against CD19 (CTL019 cells) Have Long-Term Persistence and Induce Durable Responses In Relapsed, Refractory CLL. Blood, v. 122, n. 21, p. 4162-4162, 2013.

KAROLEWSKI, B. A. et al. Comparison of Transfection Conditions for a Lentivirus Vector Produced in Large Volumes. Human Gene Therapy, v. 14, n. 14, p. 1287-1296, 20 set. 2003.

KENNEDY, A.; CRIBBS, A. P. Production and Concentration of Lentivirus for Transduction of Primary Human T Cells. In: FEDERICO, M. (Ed.). . Methods in Molecular Biology. New York, NY: Humana Press, 2016. v. 1448p. 85-93.

KERSHAW, M. H. et al. Clinical application of genetically modified T cells in cancer therapy. Clinical \& Translational Immunology, v. 3, n. 5, p. e16, 16 maio 2014.

KERSHAW, M. H.; WESTWOOD, J. A.; DARCY, P. K. Gene-engineered T cells for cancer therapy. Nature Reviews Cancer, v. 13, n. 8, p. 525-541, 1 ago. 2013.

$\mathrm{KIM}, \mathrm{D}$. W. et al. Use of the human elongation factor 1 alpha promoter as a versatile and efficient expression system. Gene, v. 91, n. 2, p. 217-23, 16 jul. 1990.

KIM, S. et al. Efficiency of the Elongation Factor-1a Promoter in Mammalian Embryonic Stem Cells Using Lentiviral Gene Delivery Systems. Stem Cells and Development, v. 16, n. 4, p. 537-546, ago. 2007.

KOCHENDERFER, J. N. et al. Construction and Preclinical Evaluation of an Anti-CD19 Chimeric Antigen Receptor. Journal of Immunotherapy, v. 32, n. 7, p. 689-702, set. 2009.

KOCHENDERFER, J. N. et al. Adoptive transfer of syngeneic T cells transduced with a chimeric antigen receptor that recognizes murine CD19 can eradicate lymphoma and normal B cells. Blood, v. 116, n. 19, p. 3875-3886, 11 nov. 2010.

KOCHENDERFER, J. N. et al. B-cell depletion and remissions of malignancy along with cytokine-associated toxicity in a clinical trial of anti-CD19 chimeric-antigenreceptor-transduced T cells. Blood, v. 119, n. 12, p. 2709-2720, 2012.

KOCHENDERFER, J. N. et al. Donor-derived CD19-targeted T cells cause regression of malignancy persisting after allogeneic hematopoietic stem cell transplantation. Blood, v. 122, n. 25, p. 151, 12 dez. 2013.

KOCHENDERFER, J. N. et al. Chemotherapy-refractory diffuse large B-cell 
lymphoma and indolent B-cell malignancies can be effectively treated with autologous $\mathrm{T}$ cells expressing an anti-CD19 chimeric antigen receptor. Journal of Clinical Oncology, v. 33, n. 6, p. 540-549, 20 fev. 2015.

KOLDEJ, R. et al. Optimisation of a multipartite human immunodeficiency virus based vector system; control of virus infectivity and large-scale production. The Journal of Gene Medicine, v. 7, n. 11, p. 1390-1399, nov. 2005.

KONO, K. et al. Prognostic significance of adoptive immunotherapy with tumorassociated lymphocytes in patients with advanced gastric cancer: a randomized trial. Clinical Cancer Research, v. 8, n. 6, p. 1767-71, jun. 2002.

KOWOLIK, C. M. et al. CD28 Costimulation Provided through a CD19-Specific Chimeric Antigen Receptor Enhances In vivo Persistence and Antitumor Efficacy of Adoptively Transferred T Cells. Cancer Research, v. 66, n. 22, p. 10995-11004, 15 nov. 2006.

KOWOLIK, C. M.; YEE, J.-K. Preferential Transduction of Human Hepatocytes with Lentiviral Vectors Pseudotyped by Sendai Virus F Protein. Molecular Therapy, v. 5 , n. 6 , p. 762-769, 1 jun. 2002.

KRAUSE, A. et al. Antigen-dependent CD28 Signaling Selectively Enhances Survival and Proliferation in Genetically Modified Activated Human Primary $T$ Lymphocytes. The Journal of Experimental Medicine, v. 188, n. 4, p. 619-626, 17 ago. 1998.

KURODA, $\mathrm{H}$. et al. Simplified lentivirus vector production in protein-free media using polyethylenimine-mediated transfection. Journal of Virological Methods, v. 157, n. 2, p. 113-121, maio 2009.

KUTNER, R. H.; ZHANG, X.-Y.; REISER, J. Production, concentration and titration of pseudotyped HIV-1-based lentiviral vectors. Nature Protocols, v. 4, n. 4, p. 495-505, 1 abr. 2009.

LEE, D. W. et al. T cells expressing CD19 chimeric antigen receptors for acute lymphoblastic leukaemia in children and young adults: A phase 1 dose-escalation trial. The Lancet, v. 385, n. 9967, p. 517-528, 2015.

LEE, S.; MARGOLIN, K. Tumor-Infiltrating Lymphocytes in Melanoma. Current Oncology Reports, v. 14, n. 5, p. 468-474, 10 out. 2012.

LEVINE, B. L. et al. Global Manufacturing of CAR T Cell Therapy. Molecular Therapy - Methods \& Clinical Development, v. 4, p. 92-101, 17 mar. 2017.

LEWIS, P. F.; EMERMAN, M. Passage through mitosis is required for oncoretroviruses but not for the human immunodeficiency virus. Journal of Virology, v. 68 , n. 1, p. 510-6, jan. 1994.

LITTMAN, D.; HEXNER, E. Cancer Immunotherapy with Chimeric Antigen Receptor (CAR) T Cells. Journal of Onco-Nephrology, v. 1, n. 3, p. 151-155, 2017.

LONG, A. H. et al. 4-1BB costimulation ameliorates T cell exhaustion induced 
by tonic signaling of chimeric antigen receptors. Nature Medicine, v. 21, n. 6, p. 58190, 4 maio 2015.

LONGO, P. A. et al. Transient mammalian cell transfection with polyethylenimine (PEI). In: Methods in Enzymology. [s.I: s.n.]. v. 529p. 227-240.

MA, B. et al. Lipoplex morphologies and their influences on transfection efficiency in gene delivery. Journal of Controlled Release, v. 123, n. 3, p. 184-194, 20 nov. 2007.

MAHER, J. et al. Human T-lymphocyte cytotoxicity and proliferation directed by a single chimeric TCR /CD28 receptor. Nature Biotechnology, v. 20, n. 1, p. 70-75, 1 jan. 2002.

MATHIS, S.; VALLAT, J.-M.; MAGY, L. Novel immunotherapeutic strategies in chronic inflammatory demyelinating polyneuropathy. Immunotherapy, v. 8, n. 2, p. 165-178, fev. 2016.

MAUDE, S.; BARRETT, D. M. Current status of chimeric antigen receptor therapy for haematological malignancies. British Journal of Haematology, v. 172, n. 1, p. 11-22, jan. 2015.

MAUDE, S. L. et al. Chimeric Antigen Receptor T Cells for Sustained Remissions in Leukemia. New England Journal of Medicine, v. 371, n. 16, p. 15071517, 2014.

MAUDE, S. L. S. L. et al. CD19-targeted chimeric antigen receptor T cell therapy for acute lymphoblastic leukemia. Blood, v. 125, n. 26, p. 4017-4023, 25 jun. 2015.

MAUS, M. V. et al. Antibody-modified T cells: CARs take the front seat for hematologic malignancies. Blood, v. 123, n. 17, p. 2625-2635, 24 abr. 2014.

MCGARRITY, G. J. et al. Patient monitoring and follow-up in lentiviral clinical trials. The Journal of Gene Medicine, v. 15, n. 2, p. 78-82, fev. 2013.

MERTEN, O.-W. State-of-the-art of the production of retroviral vectors. The Journal of Gene Medicine, v. 6, n. S1, p. S105-S124, fev. 2004.

MERTEN, O.-W. et al. Large-Scale Manufacture and Characterization of a Lentiviral Vector Produced for Clinical Ex Vivo Gene Therapy Application. Human Gene Therapy, v. 22, n. 3, p. 343-356, mar. 2011.

MERTEN, O.-W. et al. Manufectoring of viral vectors for gene therapy: part I. Upstream processing. Pharm. Bioprocess, v. 2, n. 2, p. 183-203, 2014.

MERTEN, O.-W.; HEBBEN, M.; BOVOLENTA, C. Production of lentiviral vectors. Molecular Therapy - Methods \& Clinical Development, v. 3, p. 16017, 13 abr. 2016.

MILLER, R. H.; SARVER, N. HIV accessory proteins as therapeutic targets. Nature Medicine, v. 3, n. 4, p. 389-394, 1 abr. 1997. 
MILONE, M. C. et al. Chimeric Receptors Containing CD137 Signal Transduction Domains Mediate Enhanced Survival of $\mathrm{T}$ Cells and Increased Antileukemic Efficacy In Vivo. Molecular Therapy, v. 17, n. 8, p. 1453-1464, 21 ago. 2009.

MIYOSHI, H. et al. Development of a self-inactivating lentivirus vector. Journal of Virology, v. 72, n. 10, p. 8150-7, out. 1998.

MOCK, U. et al. Automated manufacturing of chimeric antigen receptor T cells for adoptive immunotherapy using CliniMACS Prodigy. Cytotherapy, v. 18, n. 8, p. 1002-1011, ago. 2016.

MONTINI, E. et al. Hematopoietic stem cell gene transfer in a tumor-prone mouse model uncovers low genotoxicity of lentiviral vector integration. Nature Biotechnology, v. 24, n. 6, p. 687-696, 28 jun. 2006.

MONTINI, E. et al. The genotoxic potential of retroviral vectors is strongly modulated by vector design and integration site selection in a mouse model of HSC gene therapy. Journal of Clinical Investigation, v. 119, n. 4, p. 964-975, 1 abr. 2009.

MORGAN, R. A. et al. Case Report of a Serious Adverse Event Following the Administration of $\mathrm{T}$ Cells Transduced With a Chimeric Antigen Receptor Recognizing ERBB2. Molecular Therapy, v. 18, n. 4, p. 843-851, abr. 2010.

MORITA, D. et al. Enhanced Expression of Anti-CD19 Chimeric Antigen Receptor in piggyBac Transposon-Engineered T Cells. Molecular Therapy - Methods \& Clinical Development, v. 8, p. 131-140, 16 mar. 2018.

MROSS, K.; KRATZ, F. Limits of Conventional Cancer Chemotherapy. In: Drug Delivery in Oncology. Weinheim, Germany: Wiley-VCH Verlag GmbH \& Co. KGaA, 2011. p. 1-31.

NESCHADIM, A. et al. A Roadmap to Safe, Efficient, and Stable LentivirusMediated Gene Therapy with Hematopoietic Cell Transplantation. Biology of Blood and Marrow Transplantation, v. 13, n. 12, p. 1407-1416, 1 dez. 2007.

O'DOHERTY, U.; SWIGGARD, W. J.; MALIM, M. H. Human immunodeficiency virus type 1 spinoculation enhances infection through virus binding. Journal of virology, v. 74 , n. 21 , p. 10074-80, nov. 2000.

PAPANIKOLAOU, E. et al. Characterization and comparative performance of lentiviral vector preparations concentrated by either one-step ultrafiltration or ultracentrifugation. Virus Research, v. 175, n. 1, p. 1-11, jul. 2013.

PFEIFER, A. et al. Transgenesis by lentiviral vectors: Lack of gene silencing in mammalian embryonic stem cells and preimplantation embryos. Proceedings of the National Academy of Sciences, v. 99, n. 4, p. 2140-2145, 19 fev. 2002.

PICANÇO-CASTRO, V. et al. Lentiviral-mediated gene transfer - a patent review. Expert Opinion on Therapeutic Patents, v. 18, n. 5, p. 525-539, 8 maio 2008. 
RAMEZANI, A.; HAWLEY, R. G. Overview of the HIV-1 Lentiviral Vector System. In: Current Protocols in Molecular Biology. Hoboken, NJ, USA: John Wiley \& Sons, Inc., 2002. v. Chapter 16p. Unit 16.21.

RAMOS, C. A.; DOTTI, G. Chimeric antigen receptor (CAR)-engineered lymphocytes for cancer therapy. Expert Opinion on Biological Therapy, v. 11, n. 7, p. 855-873, 4 jul. 2011.

REISER, J. Production and concentration of pseudotyped HIV-1-based gene transfer vectors. Gene Therapy, v. 7, n. 11, p. 910-913, 25 jun. 2000.

REN, X. et al. Modification of cytokine-induced killer cells with chimeric antigen receptors (CARs) enhances antitumor immunity to epidermal growth factor receptor (EGFR)-positive malignancies. Cancer Immunology, Immunotherapy, v. 64, n. 12, p. 1517-1529, 19 dez. 2015.

RIBAS, A.; WOLCHOK, J. D. Cancer immunotherapy using checkpoint blockade. Science, v. 359, n. 6382, p. 1350-1355, 2018.

ROBBINS, P. F.; KAWAKAMI, Y. Human tumor antigens recognized by T cells. Current Opinion in Immunology, v. 8, n. 5, p. 628-36, out. 1996.

RODGERS, D. T. et al. Switch-mediated activation and retargeting of CAR-T cells for B-cell malignancies. Proceedings of the National Academy of Sciences of the United States of America, v. 113, n. 4, p. E459-E468, 26 jan. 2016.

SAKODA, T. et al. A High-Titer Lentiviral Production System Mediates Efficient Transduction of Differentiated Cells Including Beating Cardiac Myocytes. Journal of Molecular and Cellular Cardiology, v. 31, n. 11, p. 2037-2047, nov. 1999.

SASTRY, L. et al. Titering lentiviral vectors: comparison of DNA, RNA and marker expression methods. Gene Therapy, v. 9, n. 17, p. 1155-1162, 13 ago. 2002.

SCHEUERMANN, R. H.; RACILA, E. CD19 Antigen in Leukemia and Lymphoma Diagnosis and Immunotherapy. Leukemia \& Lymphoma, v. 18, n. 5-6, p. 385-397, 2 jan. 1995.

SCHRIEVER, F. et al. Isolated human follicular dendritic cells display a unique antigenic phenotype. The Journal of Experimental Medicine, v. 169, n. 6, p. 20432058, 1 jun. 1989.

SCHWEIZER, M.; MERTEN, O.-W. Large-Scale Production Means for the Manufacturing of Lentiviral Vectors. Current Gene Therapy, v. 10, n. 6, p. 474-486, 1 dez. 2010.

SEGURA, M. M. et al. New Protocol for Lentiviral Vector Mass Production. In: FEDERICO, M. (Ed.). . Methods in Molecular Biology. Second ed. New York, NY: Humana Press, 2010. v. 614p. 39-52.

SENA-ESTEVES, M. et al. Optimized large-scale production of high titer lentivirus vector pseudotypes. Journal of Virological Methods, v. 122, n. 2, p. 131139, 15 dez. 2004. 
SINGH, H. et al. Manufacture of Clinical-Grade CD19-Specific T Cells Stably Expressing Chimeric Antigen Receptor Using Sleeping Beauty System and Artificial Antigen Presenting Cells. PLoS ONE, v. 8, n. 5, p. e64138, 31 maio 2013.

SUERTH, J. D.; SCHAMBACH, A.; BAUM, C. Genetic modification of lymphocytes by retrovirus-based vectors. Current Opinion in Immunology, v. 24, n. 5, p. 598-608, out. 2012.

TEDDER, T. F. CD19: a promising B cell target for rheumatoid arthritis. Nature Reviews Rheumatology, v. 5, n. 10, p. 572-577, out. 2009.

TILL, B. G. et al. Adoptive immunotherapy for indolent non-Hodgkin lymphoma and mantle cell lymphoma using genetically modified autologous CD20-specific T cells. Blood, v. 112, n. 6, p. 2261-2271, 15 set. 2008.

TILL, B. G. et al. CD20-specific adoptive immunotherapy for lymphoma using a chimeric antigen receptor with both CD28 and 4-1BB domains: Pilot clinical trial results. Blood, v. 119, n. 17, p. 3940-3950, 26 abr. 2012.

TISCORNIA, G.; SINGER, O.; VERMA, I. M. Production and purification of lentiviral vectors. Nature Protocols, v. 1, n. 1, p. 241-245, 2006.

TRANSFIGURACION, J. et al. Size-Exclusion Chromatography Purification of High-Titer Vesicular Stomatitis Virus G Glycoprotein-Pseudotyped Retrovectors for Cell and Gene Therapy Applications. Human Gene Therapy, v. 14, n. 12, p. 11391153, 10 ago. 2003.

TRICKETT, A.; KWAN, Y. L.; LAM KWAN, Y. T cell stimulation and expansion using anti-CD3/CD28 beads. Journal of Immunological Methods, v. 275, n. 1-2, p. 251-255, abr. 2003.

TURTLE, C. J. et al. Durable Molecular Remissions in Chronic Lymphocytic Leukemia Treated With CD19-Specific Chimeric Antigen Receptor-Modified T Cells After Failure of Ibrutinib. Journal of Clinical Oncology, v. 35, n. 26, p. 3010-3020, 10 set. 2017.

Letter.

U.S. FOOD AND DRUG ADMINISTRATION. Kymriah BL 125646/0 Approval $<$ https://www fda gov/downloads/BiologicsBlocines/CellularGeneTherapyProdu cts/ApprovedProducts/UCM574106.pdf>. Acesso em: 3 maio. 2018a.

Letter.

U.S. FOOD AND DRUG ADMINISTRATION. Yescarta BL 125643/0 Approval <https://www fda gov/downloads/BiologicsB/ cts/ApprovedProducts/UCM581259.pdf>. Acesso em: 3 maio. 2018b.

\footnotetext{
U.S. FOOD AND DRUG ADMINISTRATION. Kymriah BL 125646/76 Supplement Approval. Disponível em: <https://www.fda.gov/downloads/BiologicsBloodVaccines/CellularGeneTherapyProdu cts/ApprovedProducts/UCM606523.pdf>. Acesso em: 3 maio. 2018.
}

UCHIDA, N. et al. Optimal conditions for lentiviral transduction of engrafting 
human CD34+ cells. Gene Therapy, v. 18, n. 11, p. 1078-1086, 5 nov. 2011.

VAN DER LOO, J. C. M.; WRIGHT, J. F. Progress and challenges in viral vector manufacturing. Human Molecular Genetics, v. 25, n. R1, p. R42-R52, 15 abr. 2016.

VERHOEYEN, E.; COSTA, C.; COSSET, F.-L. Lentiviral Vector Gene Transfer into Human T Cells. In: BAUM, C. (Ed.). . Genetic Modification of Hematopoietic Stem Cells. [s.I.] Humana Press, 2009. p. 97-114.

WATANABE, S.; TEMIN, H. M. Encapsidation sequences for spleen necrosis virus, an avian retrovirus, are between the 5' long terminal repeat and the start of the gag gene. Proceedings of the National Academy of Sciences of the United States of America, v. 79, n. 19, p. 5986-90, out. 1982.

WRIGHT, J. F. Transient Transfection Methods for Clinical Adeno-Associated Viral Vector Production. Human Gene Therapy, v. 20, n. 7, p. 698-706, jul. 2009.

WU, C.-Y. et al. Remote control of therapeutic T cells through a small moleculegated chimeric receptor. Science, v. 350, n. 6258, p. aab4077, 16 out. 2015.

YACOUB, N. AL et al. Optimized production and concentration of lentiviral vectors containing large inserts. The Journal of Gene Medicine, v. 9, n. 7, p. 579584, jul. 2007.

ZACK, J. A.; KIM, S. G.; VATAKIS, D. N. HIV restriction in quiescent CD4+ T cells. Retrovirology, v. 10, n. 1, p. 37, 4 abr. 2013.

ZENNOU, V. et al. HIV-1 Genome Nuclear Import Is Mediated by a Central DNA Flap. Cell, v. 101, n. 2, p. 173-185, 14 abr. 2000.

ZHANG, B. et al. A highly efficient and consistent method for harvesting large volumes of high-titre lentiviral vectors. Gene Therapy, v. 8, n. 22, p. 1745-1751, 17 nov. 2001.

ZHANG, C. et al. Engineering CAR-T cells. Biomarker Research, v. 5, n. 1, p. 22, 24 dez. 2017.

ZHANG, Y. et al. Transduction of Human T Cells with a Novel T-Cell Receptor Confers Anti-HCV Reactivity. PLoS Pathogens, v. 6, n. 7, p. e1001018, 29 jul. 2010.

ZHENG, Z.; CHINNASAMY, N.; MORGAN, R. A. Protein L: a novel reagent for the detection of Chimeric Antigen Receptor (CAR) expression by flow cytometry. Journal of Translational Medicine, v. 10, n. 1, p. 29, 2012.

ZUFFEREY, R. et al. Multiply attenuated lentiviral vector achieves efficient gene delivery in vivo. Nature Biotechnology, v. 15, n. 9, p. 871-875, 1 set. 1997.

ZUFFEREY, R. et al. Self-inactivating lentivirus vector for safe and efficient in vivo gene delivery. Journal of Virology, v. 72, n. 12, p. 9873-80, dez. 1998.

ZUFFEREY, R. et al. Woodchuck hepatitis virus posttranscriptional regulatory element enhances expression of transgenes delivered by retroviral vectors. Journal 
of Virology, v. 73, n. 4, p. 2886-92, abr. 1999. 
Anexos 
ANEXOS

\section{ANEXO A - Parecer consubstanciado do CEP do HC-FMRP-USP.}

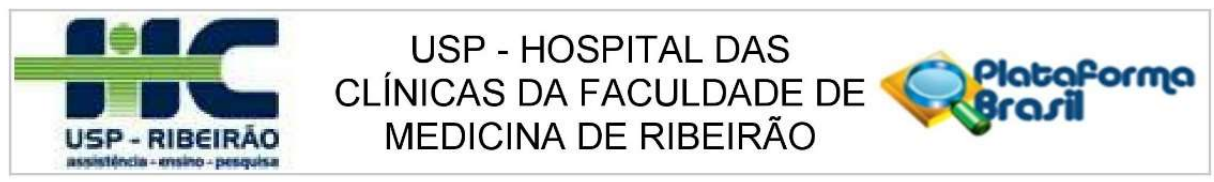

\section{PARECER CONSUBSTANCIADO DO CEP}

\section{DADOS DO PROJETO DE PESQUISA}

Título da Pesquisa: Modificação de linfócitos T com receptor de antígenos quimérico anti-CD19 Pesquisador: Pablo Diego Moço

Área Temática: Projetos de pesquisa que envolvam organismos geneticamente modificados (OGM), células-tronco embrionárias e organismos que representem alto risco coletivo, incluindo organismos relacionados a eles, nos âmbitos de: experimentação, construção, cultivo, manipulação, transporte, transferência, importação, exportação, armazenamento, liberação no meio ambiente e descarte;

Versão: 2

CAAE: 65063217.4 .0000 .5440

Instituição Proponente: Hospital das Clínicas da Faculdade de Medicina de Ribeirão Preto da USP -

Patrocinador Principal: Financiamento Próprio

DADOS DO PARECER

Número do Parecer: 1.996.240

\section{Apresentação do Projeto:}

Resumo:

A utilização de Imunoterapia com linfócitos T modificados com receptores de antígenos quiméricos (CAR) tem se mostrado eficaz no tratamento de leucemias e linfomas resistentes a quimioterapia e/ou recidiva. Os CAR possuem um domínio extracelular derivado de regiões variáveis de anticorpos e domínios intracelulares de coestimulação de linfócitos T. A proteína CD19 tem se mostrado o alvo ideal porque é expresso na maioria de tumores de células $B$, assim como células $B$ normais, mas não em outros tipos de células, restringindo o alvo apenas para células $B$. Estudos clínicos recentes envolvendo células T-CAR antiCD19 têm apresentado excelentes respostas em uma variedade de tumores de células $B$, mesmo em pacientes com recaída após quimioterapia com alta dose. O presente estudo propõe a produção de linfócitos T CAR anti-CD19 de segunda geração com 4-1BB como domínio intracelular de coestimulação. $O$ projeto será dividido em 3 fases: 1) Inicialmente será realizada a validação do CAR anti-CD19 em linhagens celulares de linfócitos $T$ Jurkat e avaliação da sua atividade citotóxica contra linhagens

Endereço: CAMPUS UNIVERSITÁRIO

Bairro: MONTE ALEGRE

UF: SP Município: RIBEIRAO PRETO

Telefone: (16)3602-2228 Fax: (16)3633-1144 E-mail: cep@hcrp.usp.br 


USP - HOSPITAL DAS
CLINICAS DA FACULDADE DE Q Platoforma
MEDICINA DE RIBEIRÃO

Continuaçäo do Parecer: 1.996 .240

de células B e contras células B CD19 + de pacientes;2) Isolamento e modificação de linfócitos T de pacientes com CAR anti CD19 e avaliação da sua atividade citotóxica.3) Desenvolvimento de um protocolo clinico para tratamento de pacientes com leucemias/linfomas (CD19+).

Objetivo da Pesquisa:

Este projeto tem por objetivo a produção de linfócitos T modificados por vetores lentivirais para a expressão de receptores de antígenos quiméricos (CAR) anti-CD19.

\section{Avaliação dos Riscos e Benefícios:}

Riscos:

Os riscos envolvidos nesta pesquisa estão relacionados aos previstos na coleta de sangue de rotina para exames: dor, formação de hematomas, ou outro desconforto no local da coleta. Os demais riscos estão relacionados à quebra de sigilo dos dados. Os pesquisadores se comprometem a tomar as providências cabíveis para que essa quebra de sigilo não ocorra.

Benefícios:

Os benefícios estão relacionados ao auxílio à pesquisa com linfócitos $T$ modificados, possibilitando que essas células possam se tornar um tipo de tratamento aos pacientes com neoplasias de células B.

\section{Comentários e Considerações sobre a Pesquisa:}

Metodologia Proposta:

A metodologia simplificada se constitui de isolamento de linfócitos, ativação de linfócitos $T$, transfecção de células para produção lentiviral, transdução lentiviral dos linfócitos T e expressão dos receptores CAR, seguida de análise de citotoxicidade contra células alvo CD19+. Inicialmente será realizada a transdução de células Hek293T, como forma de validação da metodologia. Alíquotas do sobrenadante produzido pelas células Hek293T transfectadas serão colocadas sobre a cultura da linhagem celular Hek293T. Será adicionada uma concentração viral (vírus/células) baseada nos valores obtidos pela titulação viral. Após a adição do sobrenadante viral, as células serão incubadas a $37^{\circ} \mathrm{C}$ em atmosfera úmida contendo $5 \%$ de CO2. Posteriormente o mesmo protocolo será realizado utilizando-se linhagem de linfócitos T NK-92 (ATCC $\circledast$ CRL-2407 ${ }^{\mathrm{TM}}$ ) ou Jurkat (ATCC $\circledast$ TIB-152 ${ }^{\mathrm{TM}}$ ), cultivadas em meio RPMI 10\% FBS.Amostras das células transduzidas serão coradas com anticorpos policlonais antimouse- $F(a b) 2$ para que seja detectada a expressão do CAR anti-CD19.Células NK-92 ou Jurkat modificadas serão incubadas juntamente com linhagem de linfócitos B CD19+ Raji (ATCC $®$ CCL-86 TM) ou Namalwa (ATCC $®$ CRL-1432 ${ }^{\text {TM }}$ ) em meio RPMI $10 \%$ FBS, para verificação de atividade citotóxica. As células alvo serão pré-coradas com

Endereço: CAMPUS UNIVERSITÁRIO Bairro: MONTE ALEGRE

UF: SP Município: RIBEIRAO PRETO

Telefone: (16)3602-2228 Fax: (16)3633-1144

CEP: $14.048-900$

E-mail: cep@hcrp.usp.br 


USP - HOSPITAL DAS
$\begin{gathered}\text { CLINICAS DA FACULDADE DE Slotoforma } \\ \text { MEDICINA DE RIBEIRÃO }\end{gathered}$

Continuaçäo do Parecer: 1.996 .240

corante fluorescente de membrana PKH67-GL (Sigma-Aldrich) e células efetoras serão adicionadas a fim de se obter razões efetoras:alvo (E:A) de 1:1 a 10:1. Após incubação a misturas serão coradas com iodeto de propídio. Também será analisada a citotoxicidade por citometria de fluxo, empregando-se anticorpos antiCD3 e anti-CD19.A fim de se obter linfócitos $T$, será realizado primeiramente o isolamento de linfócitos retidos no filtro de leucorredução do processo de doação de sangue e plaquetas, após esclarecimento e consentimento de doadores saudáveis $(n=10)$ (protocolos aprovados pelo Comitê de Ética em Pesquisa da Fundação Hemocentro de Ribeirão Preto, CAAE 51310015.8.0000.5440). Os linfócitos isolados serão incubados com beads magnéticas acopladas a anticorpos monoclonais anti-CD3+ (Stem Cell Technologies). Em seguida o tubo de células será incubado em uma cuba magnética (Stem Cell Technologies), levando à retenção das células com marcadores $C D 3+$. O tubo será lavado, ainda na cuba magnética, a fim de eliminar as células não marcadas e após será feita a eluição para obtenção dos linfócitos T CD3+. Para a ativação dos linfócitos T, as células serão plaqueadas em meio RPMI suplementado com $200 \mathrm{mM}$ de GlutaMAX $(\mathrm{GIBCO} \otimes)$ e $5 \%$ de soro humano $\mathrm{AB}$, para uma expansão em condições livres de xenoantígenos visando futura aplicação terapêutica do produto celular. Serão adicionados beads conjugadas a anticorpo anti-CD3 e anti-CD28 (na proporção 1:3 - beads: células) e interleucina recombinante IL-2 (PeproTech) a fim de ativar as células. A transdução será realizada como descrito anteriormente.Os linfócitos T transduzidos serão coradas com anticorpos policlonais anti-mouse- $F(a b) 2$ para que seja detectada a expressão do CAR anti-CD19, conforme descrito. Sangue periférico (12 $\mathrm{mL})$ de pacientes com malignidades de linfócitos CD19+ $(n=10)$ serão

coletados como parte de procedimentos de rotina. Consentimento será obtido de todos os pacientes. A células mononucleares (PBMC) serão purificadas por gradiente de Ficoll. Os linfócitos T modificados com CAR serão incubadas com células alvo (linfócitos B CD19+) em uma proporção de 1:1 a 10:1 E:A e a citotoxicidade será verificado com descrito anteriormente.

Considerações sobre os Termos de apresentação obrigatória:

Todos os termos de apresentação foram corrigidos conforme o parecer emitido pelo CEP e estão adequados.

Recomendações:

Não se aplica.

Conclusões ou Pendências e Lista de Inadequações:

Diante do exposto e à luz da Resolução CNS 466/2012, o projeto de pesquisa

Endereço: CAMPUS UNIVERSITÁRIO Bairro: MONTE ALEGRE

UF: SP Município: RIBEIRAO PRETO

Telefone: (16)3602-2228 Fax: (16)3633-1144

CEP: $\quad 14.048-900$

E-mail: cep@hcrp.usp.br 


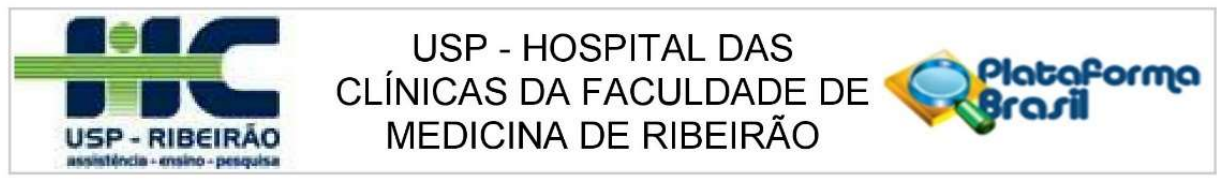

Continuaçäo do Parecer: 1.996 .240

ProjetoPabloMocoV2, assim como os Termos de Consentimento Livre e Esclarecido TCLEPacientesV2 e TCLEDoadorSaudavelV2, podem ser enquadrados na categoria APROVADO.

Considerações Finais a critério do CEP:

Projeto Aprovado: Tendo em vista a legislação vigente, devem ser encaminhados ao CEP, relatórios parciais anuais referentes ao andamento da pesquisa e relatório final ao término do trabalho. Qualquer modificação do projeto original deve ser apresentada a este CEP em nova versão, de forma objetiva e com justificativas, para nova apreciação.

O presente projeto, seguiu nesta data para análise da CONEP e só tem o seu início autorizado após a aprovação pela mesma.

Este parecer foi elaborado baseado nos documentos abaixo relacionados:

\begin{tabular}{|c|c|c|c|c|}
\hline Tipo Documento & Arquivo & Postagem & Autor & Situação \\
\hline $\begin{array}{l}\text { Informações Básicas } \\
\text { do Projeto }\end{array}$ & $\begin{array}{l}\text { PB_INFORMAÇÕES_BÁSICAS_DO_P } \\
\text { ROJETO 748663.pdf }\end{array}$ & $\begin{array}{c}28 / 03 / 2017 \\
16: 48: 25\end{array}$ & & Aceito \\
\hline $\begin{array}{l}\text { TCLE / Termos de } \\
\text { Assentimento / } \\
\text { Justificativa de } \\
\text { Ausência }\end{array}$ & TCLEPacientesV2.doc & $\begin{array}{c}28 / 03 / 2017 \\
16: 44: 50\end{array}$ & Pablo Diego Moço & Aceito \\
\hline $\begin{array}{l}\text { TCLE / Termos de } \\
\text { Assentimento / } \\
\text { Justificativa de } \\
\text { Ausência } \\
\end{array}$ & TCLEDoadorSaudavelV2.doc & $\begin{array}{c}28 / 03 / 2017 \\
16: 44: 36\end{array}$ & Pablo Diego Moço & Aceito \\
\hline $\begin{array}{l}\text { Projeto Detalhado / } \\
\text { Brochura } \\
\text { Investigador } \\
\end{array}$ & ProjetoPabloMocoV2.docx & $\begin{array}{c}28 / 03 / 2017 \\
16: 44: 16\end{array}$ & Pablo Diego Moço & Aceito \\
\hline Outros & CartaResposta.pdf & $\begin{array}{c}28 / 03 / 2017 \\
16: 42: 43 \\
\end{array}$ & Pablo Diego Moço & Aceito \\
\hline $\begin{array}{l}\text { Projeto Detalhado / } \\
\text { Brochura } \\
\text { Investigador } \\
\end{array}$ & ProjetoPabloMocoV3.docx & $\begin{array}{c}28 / 03 / 2017 \\
11: 07: 25\end{array}$ & Pablo Diego Moço & Aceito \\
\hline $\begin{array}{l}\text { TCLE / Termos de } \\
\text { Assentimento / } \\
\text { Justificativa de } \\
\text { Ausência } \\
\end{array}$ & TCLEPacientesV3.doc & $\begin{array}{c}28 / 03 / 2017 \\
11: 07: 04\end{array}$ & Pablo Diego Moço & Aceito \\
\hline $\begin{array}{l}\text { TCLE / Termos de } \\
\text { Assentimento / } \\
\text { Justificativa de } \\
\text { Ausência } \\
\end{array}$ & TCLEDoadorSaudavelV3.doc & $\begin{array}{c}28 / 03 / 2017 \\
11: 06: 18\end{array}$ & Pablo Diego Moço & Aceito \\
\hline Outros & AssAprovOrc.pdf & $\begin{array}{c}22 / 02 / 2017 \\
15: 07: 20 \\
\end{array}$ & Pablo Diego Moço & Aceito \\
\hline Folha de Rosto & FolhaRostoAssinaturas.pdf & $\begin{array}{c}17 / 02 / 2017 \\
09: 40: 12 \\
\end{array}$ & Pablo Diego Moço & Aceito \\
\hline Cronograma & Cronograma.docx & $14 / 02 / 2017$ & Pablo Diego Moço & Aceito \\
\hline
\end{tabular}

Endereço: CAMPUS UNIVERSITÁRIO

Bairro: MONTE ALEGRE

UF: SP Município: RIBEIRAO PRETO

Telefone: (16)3602-2228

CEP: $14.048-900$

ax: (16)3633-1144

E-mail: cep@hcrp.usp.br 


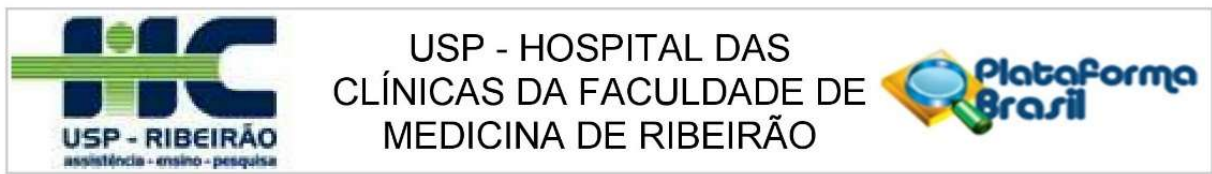

Continuação do Parecer: 1.996 .240

\begin{tabular}{|l|l|c|l|c|}
\hline Cronograma & Cronograma.docx & $15: 32: 14$ & Pablo Diego Moço & Aceito \\
\hline Orçamento & OrcamentoPabloMoco.docx & $14 / 02 / 2017$ & Pablo Diego Moço & Aceito \\
& & $15: 24: 20$ & & \\
\hline
\end{tabular}

Situação do Parecer:

Aprovado

Necessita Apreciação da CONEP:

Sim

RIBEIRAO PRETO, 03 de Abril de 2017

Assinado por:

MARCIA GUIMARÃES VILLANOVA

(Coordenador)

Endereço: CAMPUS UNIVERSITÁRIO

Bairro: MONTE ALEGRE

UF: SP Município: RIBEIRAO PRETO

CEP: $14.048-900$

Telefone: (16)3602-2228 Fax: (16)3633-1144

E-mail: cep@hcrp.usp.br

Pàgina 05 de 05 


\section{ANEXO B - Parecer consubstanciado do CONEP.}

\section{COMISSÃO NACIONAL DE Ṕ Platoforma
ÉTICA EM PESQUISA}

\section{PARECER CONSUBSTANCIADO DA CONEP}

\section{DADOS DO PROJETO DE PESQUISA}

Título da Pesquisa: Modificação de linfócitos T com receptor de antígenos quimérico anti-CD19 Pesquisador: Pablo Diego Moço

Área Temática: Projetos de pesquisa que envolvam organismos geneticamente modificados (OGM), células-tronco embrionárias e organismos que representem alto risco coletivo, incluindo organismos relacionados a eles, nos âmbitos de: experimentação, construção, cultivo, manipulação, transporte, transferência, importação, exportação, armazenamento, liberação no meio ambiente e descarte;

Versão: 5

CAAE: 65063217.4 .0000 .5440

Instituição Proponente: Hospital das Clínicas da Faculdade de Medicina de Ribeirão Preto da USP -

Patrocinador Principal: Fundação Hemocentro de Riberão Preto

\section{DADOS DO PARECER}

Número do Parecer: 2.183 .633

\section{Apresentação do Projeto:}

As informações contidas nos campos "Apresentação do Projeto", "Objetivo da Pesquisa" e "Avaliação dos Riscos e Benefícios" foram obtidas dos documentos apresentados para apreciação ética e das informações inseridas pelo Pesquisador Responsável do estudo na Plataforma Brasil.

\section{INTRODUÇÃO}

Imunoterapia para o câncer

Os tratamentos convencionais para o câncer (quimioterapia e radioterapia) apresentam limitações: não são seletivos ou específicos e afetam tanto as células tumorais como as normais. Estes tratamentos não são efetivos, de maneira geral, para eliminar as células-tronco tumorais e muitas vezes são apenas paliativos e debilitam as defesas naturais do organismo contra o câncer. Nos últimos anos, o aparecimento de moléculas seletivas, capazes de bloquear vias específicas envolvidas na regulação do crescimento tumoral, significou um enorme progresso para o tratamento, porém o potencial de cura ainda depende da associação com as terapias convencionais. A imunoterapia consiste em abordagens tecnológicas que utilizam componentes do

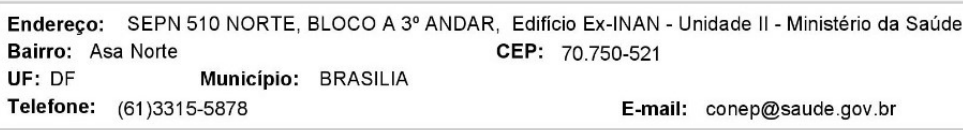




\section{COMISSÃO NACIONAL DE ÉTICA EM PESQUISA}

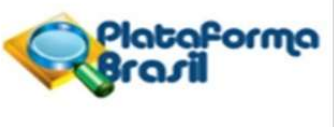

Continuação do Parecer: 2.183 .633

sistema imunológico no tratamento de doenças neoplásicas, inflamatórias e imunomediadas. A imunoterapia celular é caracterizada pela utilização de células do sistema imune com finalidades terapêuticas. A imunoterapia para o tratamento do câncer é, atualmente, a terapia mais promissora tendo em vista a sua seletividade, o seu potencial curativo e a sua baixa toxicidade. Este tipo de terapia foi descrito como o grande acontecimento científico de 2013 pela revista Science com destaque para as terapias com anticorpos monoclonais (anti-CTLA-4 e anti-PD1) e para as células T geneticamente modificadas com receptores de antígenos quiméricos, que foram capazes de induzir potente resposta antitumoral. Atualmente, diversos trabalhos mostraram que uma abordagem totalmente imunológica pode causar regressão de uma grande variedade de cânceres humanos. Esses resultados positivos vieram do recente sucesso do uso de anticorpos monoclonais (mAbs) que tem como alvos: ativação do sistema imune, incluindo a proteína 4 associada a linfócito T (CTLA-4) e morte celular programada de proteína 1 (PD-1). Isto inclui pacientes afetados com uma lista cada vez maior de doenças malignas, incluindo melanoma, carcinoma de células renais, câncer de pulmão e gastrointestinal. Apesar de diferentes mecanismos de ação, essas imunoterapias culminam com a ativação e ampliação de células $T$ tumorreativa. Como as células T são muitas vezes as imunomediadoras finais da regressão do câncer, novas estratégias que utilizam diretamente as células T tumor-reativa como uma terapia foram desenvolvidas. Células T antitumorais podem ser extraídas a partir da remoção cirúrgica de uma metástase do câncer de modo a obter os linfócitos infiltrantes de tumor (TIL). Apesar da eficácia comprovada, a identificação e expansão de TILs é de extrema dificuldade o que impede a sua ampla aplicação clínica. Progressos em tecnologias de engenharia genética tem simplificado a geração de células T antitumoral, superando muitas das barreiras práticas que têm limitado a ampla utilização de células TIL. A especificidade das células T pode ser redirecionada, artificialmente, pela introdução de uma estrutura de reconhecimento sintético chamado de receptor antígeno quimérico (CAR). A molécula CAR combina o domínio de um anticorpo de cadeia única (scFv) a partir de um anticorpo de ligação que confere o reconhecimento de um antígeno associado a tumores, além disso, apresenta proteínas intracelulares capazes de ativar a célula T. A terapia celular utilizando células $T$ geneticamente modificadas para expressar um receptor de antígeno quimérico (CAR) contra um antígeno associado a tumor é uma abordagem imunoterapêutica emergente para uma variedade de doenças neoplásicas, incluindo linfomas e leucemias. Esta tecnologia permite que estes linfócitos reconheçam moléculas presentes na superfície das células do tumor independente do sistema MHC, tornando a resposta antitumoral mais efetiva.

\footnotetext{
Endereço: SEPN 510 NORTE, BLOCO A $3^{\circ}$ ANDAR, Edifício Ex-INAN - Unidade II - Ministério da Saúde Bairro: Asa Norte CEP: 70.750-521

UF: DF Município: BRASILIA

Telefone: (61)3315-5878
} 


\section{COMISSÃO NACIONAL DE ÉTICA EM PESQUISA}

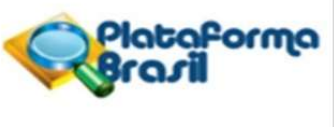

Continuaçäo do Parecer: 2.183 .633

Células T geneticamente modificadas (CAR)

Os primeiros linfócitos T modificados com CAR descritos reconhecem o alvo de maneira independente de HLA. Tais receptores possuem um domínio de reconhecimento extracelular e domínios de sinalização intracelulares. O domínio extracelular é geralmente derivado de regiões variáveis de anticorpos, enquanto o domínio intracelular pode combinar sinais do complexo de receptores e de moléculas coestimulatórias dos linfócitos T. Atualmente as estruturas dos CARs são divididas em 3 gerações. A primeira consiste apenas de uma estrutura de receptor extracelular baseado em anticorpo e um domínio intracelular que inclui o Motivo de Ativação do Imunorreceptor Baseado em Tirosina (ITAM) do FcRc e TCR, que apesar de apresentar atividade in vivo, a eficácia e a persistência in vivo dos linfócitos $T$ são baixas. Ao se adicionar domínios de sinalização coestimulatórios, como CD28 ou 4-1BB, são obtidos os CAR de segunda geração. Esses CARs apresentam persistência e eficácia clínica melhoradas. A terceira geração compreende CARs que possuem três ou mais domínios citosólicos de coestimulação, entre eles CD27, CD28, ICOS, 4-1BB, OX40, o que em tese aumentaria a potência desses linfócitos T contra tumores. Porém, um ensaio clínico usando CD28 e 41BB como coestimuladores não apresentou respostas surpreendentes.

Imunoterapia com linfócitos T CAR

CD19 é uma glicoproteína de 95 kDa presente nas células B de desenvolvimento inicial até em células diferenciadas plasmáticas. O CD19 é expresso em um complexo com CD21 e CD81 um grupo de moléculas de superfície, também referido como complexo CD19, que exige, para a sua ativação, ligação do receptor das células $B$ e uma molécula coestimulatória importante, o CD40. A ligação deste complexo das células B e correceptor pode reduzir o limiar de antígeno necessário para ativar as células B. A expressão de CD19 é restrita às células da linhagem $B$. CD19 também é expresso pela maioria dos linfomas de células $B$, linfoma de células do manto, leucemias (ALLs, CLLs), e um subconjunto de leucemias mieloide aguda. CD19 representa, portanto, um alvo muito atraente para imunoterapia. Além disso, a CD19 não está presente na maioria dos tecidos normais, exceto em células B normais, o que o torna um alvo CD19 relativamente seguro, apresentando um risco mínimo de doença autoimune ou irreversível. Malignidades de linfócitos $B$ compreendem um grupo heterogêneo de neoplasmas que incluem a maioria dos linfomas não -Hodgkin $(\mathrm{NHL})$, leucemias linfoides crônicas (CLL) e também leucemias linfoides agudas (ALL). Aproximadamente 20.000 novos casos de linfomas não-Hodgkin e leucemias são estimados para 2016 no Brasil, a maioria destes tem origem de linfócitos B. A maioria dos pacientes com ALL apresenta trombocitopenia, anemia e/ou neutropenia, que são evidencias e consequências de insuficiência

\footnotetext{
Endereço: SEPN 510 NORTE, BLOCO A $3^{\circ}$ ANDAR, Edifício Ex-INAN - Unidade II - Ministério da Saúde Bairro: Asa Norte

UF: DF Município: BRASILIA CEP: $70.750-521$

Telefone: (61)3315-5878

E-mail: conep@saude.gov.br
} 


\section{COMISSÃO NACIONAL DE ÉTICA EM PESQUISA}

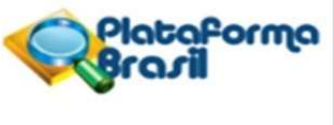

Continuação do Parecer: 2.183 .633

da medula óssea. Frequentemente, os pacientes apresentam linfadenopatia, hepatomegalia e esplenomegalia. Terapias com linfócitos T modificados com CAR anti-CD19 são, atualmente, as mais testadas contra malignidades de linfócitos B. Respostas clínicas surpreendentes e atividade robusta foram demonstradas em ensaios clínicos em leucemias linfoide crônica e aguda. Ensaios clínicos em CLL mostram que linfócitos T CAR anti-CD19, contendo o domínio de coestimulação 4-1BB conseguem proliferar com sucesso in vivo, eliminando a doença e apresentando atividade funcional por mais de 3 anos. Estudos de 3 diferentes grupos relatam taxas de remissão completa de $70 \%$ a $90 \%$ dos pacientes com ALL tratados com linfócitos T CAR anti-CD19. A persistência dos linfócitos T CAR parece ser superior em pacientes com CLL, apesar das taxas de remissão completa serem superiores no tratamento de ALL. Todos os pacientes que respondem ao tratamento desenvolvem aplasia de linfócitos B e hipogamagobulinemia, que apesar de serem considerados como resultado de toxicidade "on-target", também é uma medida de persistência funcional.

Justificativa

A Organização Mundial da Saúde estimou a existência de quase 33 milhões de pessoas vivendo com câncer em todo o globo no ano de 2012. No mesmo ano, foram diagnosticados 14,1 milhões de casos novos e morreram 8,2 milhões de pessoas em decorrência da doença, totalizando $13 \%$ das mortes por ano no mundo. Nas últimas décadas, o câncer tornou-se um problema de saúde pública mundial. No Brasil, as neoplasias são a segunda causa de mortalidade, representando 17\% do total de óbitos ocorridos em 2011. O Instituto Nacional de Câncer projetou para 2014 a ocorrência de 576 mil casos novos de câncer, o que representa um incremento de $20 \%$ na incidência na última década. De forma geral, duas em cada três pessoas serão diagnosticadas com câncer durante suas vidas. O tratamento convencional de leucemias e linfomas com transplante alogênico de células-tronco hematopoiéticas tem se demonstrado menos eficaz quando comparado com outras leucemias, além de haver o risco de doença do enxerto contra o hospedeiro. Uma alternativa atualmente estudada é a imunoterapia com linfócitos $\mathrm{T}$ do próprio paciente. Linfócitos $\mathrm{T}$ modificados para expressarem receptores quiméricos (CAR) têm se mostrado eficazes como terapia celular no tratamento de ALL e CLL. A proteína CD19, presente na superfície de linfócitos $B$, representa um alvo ideal para a ligação do linfócito T CAR, pois não está presente em outros tipos celulares essenciais e possui elevada expressão em praticamente todas as leucemias. Desta forma, o presente estudo propõe a produção de linfócitos T modificados com CAR anti-CD19 como uma alternativa terapêutica. Esses linfócitos modificados se mostram um tipo promissor de terapia celular que ainda não está sendo desenvolvido por nenhum grupo de

\footnotetext{
Endereço: SEPN 510 NORTE, BLOCO A $3^{\circ}$ ANDAR, Edifício Ex-INAN - Unidade II - Ministério da Saúde Bairro: Asa Norte CEP: $70.750-521$

UF: DF Município: BRASILIA

Telefone: (61)3315-5878
} 


\section{COMISSÃO NACIONAL DE ÉTICA EM PESQUISA}

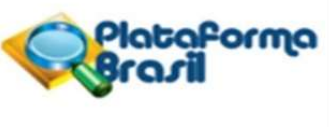

Continuação do Parecer: 2.183 .633

pesquisa brasileiro. Este trabalho será realizado na Fundação Hemocentro de Ribeirão Preto (FMRP) que faz parte do CTC (Centro de Terapia Celular), um dos centros apoiados pela FAPESP/CEPID (Centro de Pesquisa, Inovação e Difusão; Processo N²013/08135-2). Este projeto está inserido na META 12 do nosso СTC, a qual visa novas abordagens de Terapias Celulares.

HIPÓTESE

Linfócitos T modificados com CAR anti-CD19 são efetivos para destruir especificamente células B CD19 positivas.

\section{METODOLOGIA}

A metodologia simplificada se constitui de isolamento de linfócitos, ativação de linfócitos $T$, transfecção de células para produção lentiviral, transdução lentiviral dos linfócitos $T$ e expressão dos receptores CAR, seguida de análise de citotoxicidade contra células alvo CD19+. Inicialmente será realizada a transdução de células Hek293T, como forma de validação da metodologia. Alíquotas do sobrenadante produzido pelas células Hek293T transfectadas serão colocadas sobre a cultura da linhagem celular Hek293T. Será adicionada uma concentração viral (vírus/células) baseada nos valores obtidos pela titulação viral. Após a adição do sobrenadante viral, as células serão incubadas a $37^{\circ} \mathrm{C}$ em atmosfera úmida contendo $5 \%$ de CO2. Posteriormente o mesmo protocolo será realizado utilizando-se linhagem de linfócitos T NK-92 (ATCC $₫$ CRL-2407 ${ }^{\mathrm{TM}}$ ) ou Jurkat (ATCC $\circledast$ TIB-152 ${ }^{\mathrm{TM}}$ ), cultivadas em meio RPMI 10\% FBS. Amostras das células transduzidas serão coradas com anticorpos policlonais antimouse- $F(a b) 2$ para que seja detectada a expressão do CAR anti-CD19. Células NK-92 ou Jurkat modificadas serão incubadas juntamente com linhagem de linfócitos B CD19+ Raji (ATCC $\otimes_{\text {C CL- }} 6^{\mathrm{TM}}$ ) ou Namalwa (ATCC ${ }^{\mathrm{C}} \mathrm{CRL}-1432^{\mathrm{TM}}$ ) em meio RPMI $10 \%$ FBS, para verificação de atividade citotóxica. As células alvo serão pré-coradas com corante fluorescente de membrana PKH67-GL (Sigma-Aldrich) e células efetoras serão adicionadas a fim de se obter razões efetoras : alvo (E:A) de 1:1 a 10:1. Após incubação a misturas serão coradas com iodeto de propídio. Também será analisada a citotoxicidade por citometria de fluxo, empregando-se anticorpos antiCD3 e anti-CD19. A fim de se obter linfócitos $T$, será realizado primeiramente o isolamento de linfócitos retidos no filtro de leucorredução do processo de doação de sangue e plaquetas, após esclarecimento e consentimento de doadores saudáveis $(n=10)$ (protocolos aprovados pelo Comitê de Ética em Pesquisa da Fundação Hemocentro de Ribeirão Preto, CAAE 51310015.8.0000.5440). Os linfócitos isolados serão incubados com beads magnéticas acopladas a anticorpos monoclonais anti-CD3+ (Stem Cell Technologies). Em seguida

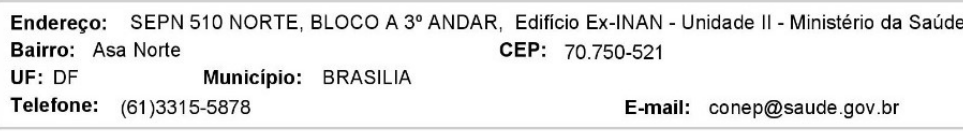




\section{COMISSÃO NACIONAL DE ÉTICA EM PESQUISA}

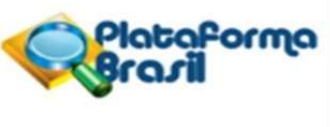

Continuação do Parecer: 2.183 .633

o tubo de células será incubado em uma cuba magnética (Stem Cell Technologies), levando à retenção das células com marcadores CD3+. O tubo será lavado, ainda na cuba magnética, a fim de eliminar as células não marcadas e após será feita a eluição para obtenção dos linfócitos T CD3+. Para a ativação dos linfócitos T, as células serão plaqueadas em meio RPMI suplementado com 200 mM de GlutaMAX (GIBCO®) e $5 \%$ de soro humano $A B$, para uma expansão em condições livres de xenoantígenos visando futura aplicação terapêutica do produto celular. Serão adicionados beads conjugadas a anticorpo anti-CD3 e anti-CD28 (na proporção 1:3 - beads : células) e interleucina recombinante IL-2 (PeproTech) a fim de ativar as células. A transdução será realizada como descrito anteriormente. Os linfócitos $T$ transduzidos serão coradas com anticorpos policlonais anti-mouse- $\mathrm{F}(\mathrm{ab}) 2$ para que seja detectada a expressão do CAR antiCD19, conforme descrito. Sangue periférico $(12 \mathrm{~mL})$ de pacientes com malignidades de linfócitos CD19+ $(n=10)$ serão coletados como parte de procedimentos de rotina. Consentimento será obtido de todos os pacientes. A células mononucleares (PBMC) serão purificadas por gradiente de Ficoll. Os linfócitos T modificados com CAR serão incubadas com células alvo (linfócitos B CD19+) em uma proporção de 1:1 a 10:1 E:A e a citotoxicidade será verificado com descrito anteriormente.

\section{CRITÉRIOS DE INCLUSÃO}

Os sujeitos de pesquisa do GRUPO "Pacientes Leucemia CD19+" devem ser portadores de leucemia de células B com expressão de CD19.

\section{CRITÉRIOS DE EXCLUSÃO}

Os sujeitos de pesquisa do GRUPO "Pacientes Leucemia CD19+" não podem possuir infecções ativas, nem estarem sendo tratados com anticorpos monoclonais (imunobiológicos) anti-CD19.

\section{Objetivo da Pesquisa:}

\section{OBJETIVOS PRIMÁRIOS}

Este projeto tem por objetivo a produção de linfócitos T modificados por vetores lentivirais para a expressão de receptores de antígenos quiméricos (CAR) anti-CD19.

\section{OBJETIVOS SECUNDÁRIOS}

Produção lentiviral dos vetores CAR em linhagem celular;

Transdução de linhagens celulares e de linfócitos T;

Análise de expressão do CAR por citometria de fluxo;

Análise de citotoxicidade dos linfócitos T CAR contra linhagens celulares e linfócitos B de

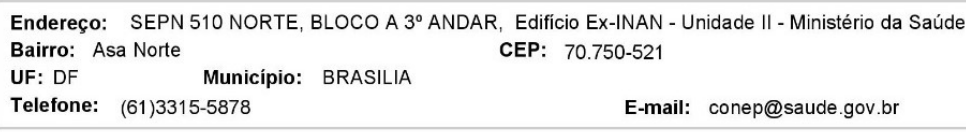




\section{COMISSÃO NACIONAL DE ÉTICA EM PESQUISA}

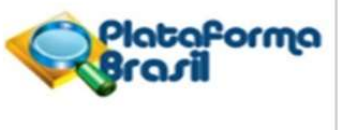

Continuação do Parecer: 2.183.633

pacientes com leucemia/linfoma CD19+

\section{Avaliação dos Riscos e Benefícios:}

RISCOS

Os riscos envolvidos nesta pesquisa estão relacionados aos previstos na coleta de sangue de rotina para exames: dor, formação de hematomas, ou outro desconforto no local da coleta. Os demais riscos estão relacionados à quebra de sigilo dos dados. Os pesquisadores se comprometem a tomar as providências cabiveis para que essa quebra de sigilo não ocorra.

\section{BENEFÍCIOS}

Os benefícios estão relacionados ao auxílio à pesquisa com linfócitos $T$ modificados, possibilitando que essas células possam se tornar um tipo de tratamento aos pacientes com neoplasias de células B.

\section{Comentários e Considerações sobre a Pesquisa:}

Protocolo de pesquisa unicêntrico que visa analisar a capacidade de resposta de linfócitos T modificados por transfecção com receptor de antígeno quimérico contra CD19 (expresso normalmente em linfócitos B) em população de linfócitos $B$ coletados de participantes de pesquisa com diferentes formas de leucemia. $O$ protocolo prevê uma etapa inicial de avaliação da técnica de transfecção e expressão em linhagens comerciais. Após a otimização dos processos, será utilizado linfócitos $T$ de participantes de pesquisa saudáveis e caso a transfecção e expressão seja adequada, será testado a citotoxicidade contra linfócitos B coletados de participantes de pesquisa com diferentes formas de leucemia.

População do estudo:

a) Participantes de pesquisa saudáveis: 10 participantes recrutados no momento em que forem ao Hemocentro de Ribeirão Preto para doação voluntária de plaquetas.

b) Participantes de pesquisa com leucemia: 10 participantes de pesquisa recrutados durante a visita de rotina ao ambulatório do Hospital das Clínicas da USP com idade entre 18 e 70 anos, com malignidades de linfócitos CD19+ (leucemia linfoide crônica não tratada, subtipos A e B; e linfomas leucemizados).

O trabalho será realizado na Fundação Hemocentro de Ribeirão Preto (FMRP).

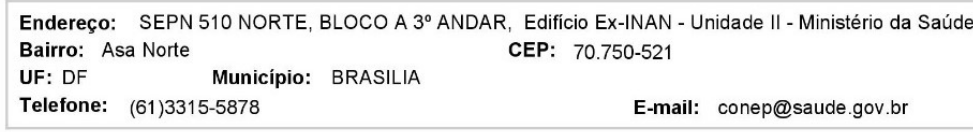




\section{COMISSÃO NACIONAL DE ÉTICA EM PESQUISA}

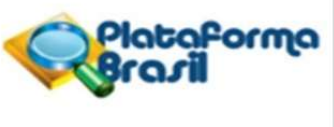

Continuaçäo do Parecer: 2.183 .633

O CEP do Hospital das Clínicas da Faculdade de Medicina de Ribeirão Preto da USP - HCFMRP/USP aprovou o protocolo em 03/04/2017 (PB_PARECER_CONSUBSTANCIADO_CEP_1996240.pdf).

Considerações sobre os Termos de apresentação obrigatória:

Em resposta ao Parecer Consubstanciado CONEP n ${ }^{\circ} 2.159 .988$ de 06/07/2017 foram postados os seguintes documentos (18/07/2017):

•PB_INFORMAÇÕES_BÁSICAS_DO_PROJETO_748663.pdf de 18/07/2017

- CartaRespostaAssinada.pdf

- CartaResposta.docx

- TCLEPacientesV5.doc

- TCLEDoadorSaudavelV5.doc

- DeclaracaoBiorrep.docx

- DeclaracaoBiorrep.pdf

Em resposta ao Parecer Consubstanciado CONEP n ${ }^{\circ} 2.057 .804$ de 11/05/2017 foram postados os seguintes documentos (06/06/2017):

•PB_INFORMAÇÕES_BÁSICAS_DO_PROJETO_748663.pdf de 06/06/2017

- folhaderosto_assin.pdf

- carta_resposta_assin.pdf

- TermoBiorrepositorioPacientesV1.docx

- TermoBiorepositorioDoadoresV1.docx

- TCLEPacientesV4.doc

- TCLEDoadorSaudaveIV4.doc

- biorrepositorio_assin.pdf

- Termo_anuencia_assin.pdf

- ProjetoPabloMocoV4.docx

- infraestrutura_assin.pdf

Documentos postados na submissão inicial (28/03/2017):

-PB_INFORMAÇÕES_BÁSICAS_DO_PROJETO_748663.pdf de 28/03/2017

- TCLEPacientesV2.doc

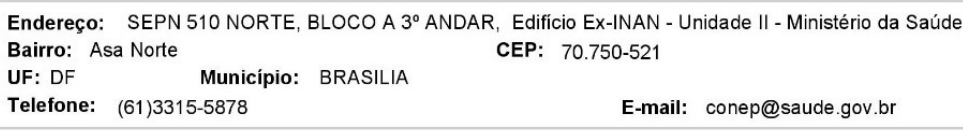




\section{COMISSÃO NACIONAL DE ÉTICA EM PESQUISA}

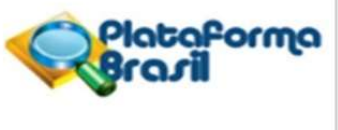

Continuação do Parecer: 2.183.633

- TCLEDoadorSaudavelV2.doc

- ProjetoPabloMocoV2.docx

- CartaResposta.pdf

- ProjetoPabloMocoV3.docx

- TCLEPacientesV3.doc

- TCLEDoadorSaudavelV3.doc

- AssAprovOrc.pdf

- FolhaRostoAssinaturas.pdf

- Cronograma.docx

- OrcamentoPabloMoco.docx

Recomendações:

Verificar item "Conclusões ou Pendências e Lista de Inadequações".

Conclusões ou Pendências e Lista de Inadequações:

Análise de respostas ao Parecer Consubstanciado CONEP n².057.804 de 11/05/2017 e Parecer

Consubstanciado CONEP n².159.988 de 06/07/2017:

1. Quanto à folha de rosto, documento intitulado "FolhaRostoAssinaturas.pdf", e às informações prestadas na Plataforma Brasil, documento "PB_INFORMAÇÕES_BÁSICAS_DO_PROJETO_748663.pdf", solicita-se o adequado preenchimento do campo "Patrocinador", pois, conforme os documentos "OrcamentoPabloMoco.docx" e "AssAprovOrc.pdf", os recursos utilizados serão providos pelo Instituto Nacional de Ciência e Tecnologia em Células-Tronco e Terapia Celular, sendo essa instituição, portanto, a patrocinadora, conforme a definição de patrocinador do item II.11 da Resolução CNS n 466 de 2012 e a exigência do item 3.3.a da Norma Operacional CNS nº 001 de 2013. Ressalta-se que apesar de não ser exigida assinatura dos responsáveis pelos órgãos nacionais de fomento à pesquisa, é necessário o preenchimento adequado das informações

RESPOSTA: A Fundação Hemocentro de Ribeirão Preto foi identificada como "patrocinador" na Plataforma Brasil, pois o Instituto Nacional de Ciência e Tecnologia em Célula-Tronco e Terapia Celular é um instituto de pesquisa vinculado à Fundação Hemocentro.

ANÁLISE: PENDÊNCIA ATENDIDA

2. Quanto ao projeto detalhado, documento intitulado "ProjetoPabloMocoV3.docx", considerando

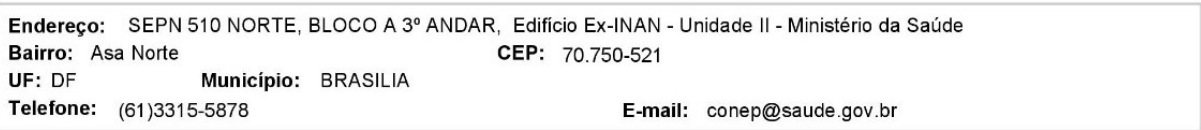




\section{COMISSÃO NACIONAL DE ÉTICA EM PESQUISA}

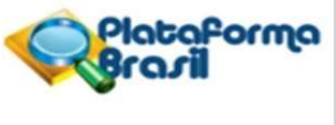

Continuaçäo do Parecer: 2.183.633

que os dados pessoais serão identificados, solicita-se que sejam indicados os procedimentos que garantam o sigilo, confidencialidade e segurança no tratamento dos dados, conforme Resolução CNS n ${ }^{\circ} 466$ de 2012 , item III.2.i.

RESPOSTA: Foi adicionado ao Projeto na seção 5 , que os pesquisadores se comprometem a identificar as amostras e os dados coletados de modo que garanta o sigilo e a confidencialidade dos doadores, identificando as amostras por meio de códigos.

ANÁLISE: PENDÊNCIA ATENDIDA

3. Quanto aos termos de consentimento livre e esclarecido (TCLE), documentos intitulados "TCLEPacientesV3.doc" e "TCLEDoadorSaudavelV3.doc":

3.1. Solicita-se utilizar a terminologia "Participante de Pesquisa" ao invés de "Paciente" nos TCLEs, conforme preconizado e definido na Resolução CNS n 466 de 2012, item II.10.

RESPOSTA: Os TCLEs foram alterados para constar "participante da pesquisa" no lugar de "paciente";

ANÁLISE: PENDÊNCIA ATENDIDA

3.2. Em relação aos riscos, solicita-se a inserção de informação sobre o risco da quebra de sigilo e que será prestada a assistência necessária em caso de danos de qualquer natureza, conforme Resolução CNS $\mathrm{n}^{\circ}$ 466 de 2012, itens IV.3.c e V.6.

RESPOSTA: Foram inseridas informações quanto sobre o risco de quebra de sigilo e que será prestada a assistência necessária em caso de danos de qualquer natureza;

ANÁLISE: PENDÊNCIA ATENDIDA

3.3. O documento deve informar se as amostras biológicas serão utilizadas apenas para os propósitos descritos no protocolo (e destruídas após a sua utilização) e/ou se haverá armazenamento para utilização em investigações futuras. Solicita-se adequar o documento, informando ao participante que, em caso de utilização das amostras para pesquisas futuras, ele será contatado para novo consentimento.

RESPOSTA: Foi criado novos Termos de Consentimento para a guarda de material biológico, que serão apresentados aos participantes de pesquisa no momento que assinarem os TCLEs para coleta de material biológico. Foi adicionado aos TCLEs de coleta que as amostras serão armazenadas e que em caso de nova pesquisa o participante será contratado para novo

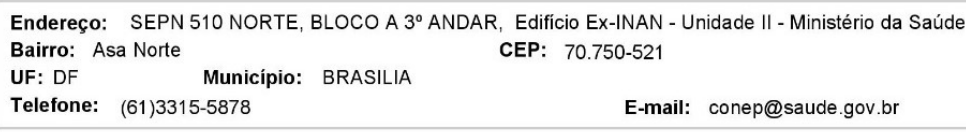




\section{COMISSÃO NACIONAL DE ÉTICA EM PESQUISA}

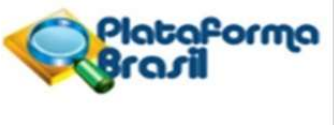

Continuação do Parecer: 2.183 .633

consentimento.

ANÁLISE: PENDÊNCIA PARCIALMENTE ATENDIDA. As informações e o consentimento para a coleta, o armazenamento e o uso do material biológico atrelado a um projeto de pesquisa deverá ser inserido no TCLE da própria pesquisa, e não em um documento separado. O documento apresenta diversos termos técnicos que podem não ser de compreensão do participante da pesquisa, interferindo em sua autonomia no momento de decisão. Solicita-se a retirada de tais termos, ou que após a citação haja uma breve explicação de seu significado. Solicita-se adequação.

RESPOSTA: As informações e o consentimento para a coleta, o armazenamento e o uso do material biológico foram inseridos nos TCLEs da própria pesquisa no item "O que será realizado com as células do participante da pesquisa?". Foram retirados também os termos técnicos. Ao final do documento foram adicionados campos para dados de contato do participante da pesquisa, para que ele possa ser contatado para uma eventual utilização de suas amostras em outras pesquisas. Todas as alterações estão destacadas em vermelho. Documentos TCLEDoadorSaudaveIV5.doc e TCLEPacientesV5.doc. Os arquivos TermoBiorepositorioDoadoresV1.doc e TermoBiorrepositorioPacientesV1.doc foram excluídos. ANÁLISE: PENDÊNCIA ATENDIDA.

4. Quanto à formação de Biorrepositório, caracterizado pela necessidade de armazenamento das amostras para realização dos ensaios celulares descritos no protocolo de pesquisa: a análise do Protocolo de Pesquisa indica que de fato haverá formação de biorrepositório. Assim sendo, todos os aspectos relativos à formação de biorrepositório ao longo da execução de uma pesquisa deverão ser seguidos, conforme explicitado na Resolução CNS 441/11 e na Portaria MS 2201/11, ainda que o armazenamento do material biológico seja temporário e sem previsão de uso futuro. Solicita-se uma revisão das referidas normativas e apresentação de:

4.1. Justificativa quanto à necessidade e oportunidade para utilização futura das amostras biológicas armazenadas no estudo (Item 2.I da Resolução CNS n 441 de 2011), se pertinente.

RESPOSTA: Foram anexados documentos para criação de biorrepositório, junto com os TCLEs que serão assinados pelos participantes da pesquisa aprovando o armazenamento de suas amostras biológicas.

ANÁLISE: PENDÉNCIA NÃO ATENDIDA. No documento "PB_INFORMAÇÕES_BÁSICAS_DO_PROJETO_748663.pdf" de 06/06/2017 lê-se: "Haverá formação de biorrepositório, no qual as amostras coletados dos participantes da pesquisa serão

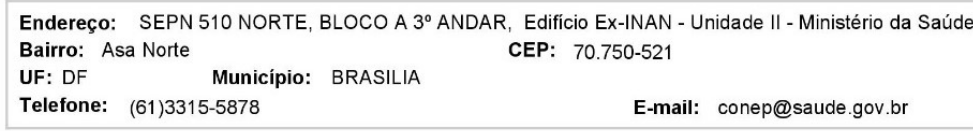




\section{COMISSÃO NACIONAL DE ÉTICA EM PESQUISA}

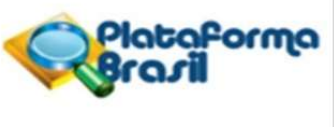

Continuação do Parecer: 2.183 .633

armazenadas PARA USO EM PESQUISAS FUTURAS" (destaque nosso). Assim sendo, conforme solicitado no Parecer Consubstanciado CONEP n² 2.057 .804 de 11/05/2017, solicita-se apresentar justificativa quanto à necessidade e oportunidade para utilização futura das amostras biológicas armazenadas no biorrepositório atrelado ao projeto de pesquisa em tela (Item 2.I da Resolução CNS nº 441 de 2011).

RESPOSTA: A criação do biorrepositório se justifica na dificuldade de obtenção de células de pacientes de leucemia e linfoma leucemizado, que por muitas vezes vêm a óbito. Desse modo, se necessário durante o curso da atual pesquisa, poderemos utilizar as células armazenadas no biorrepositório, sem precisarmos realizar uma nova coleta de células de um novo paciente. Se, por ventura, uma nova pesquisa vier a necessitar de células com tais característica, as células armazenadas no biorrepositório poderão ser utilizadas. Declaramos que toda nova pesquisa a ser realizada com material do biorrepositório precisará ser aprovada pelo CEP institucional e, quando for o caso, pelo CONEP.

ANÁLISE: PENDÊNCIA ATENDIDA.

4.2. Declaração de que toda nova pesquisa a ser realizada com o material armazenado em biorrepositório será submetida para aprovação do Comitê de Ética em Pesquisa (CEP) institucional e, quando for o caso, da Comissão Nacional de Ética em Pesquisa (CONEP) (Item 2.III, da Resolução CNS n 441 de 2011), se pertinente.

RESPOSTA: Foram anexados documentos para criação de biorrepositório, junto com os TCLEs que serão assinados pelos participantes da pesquisa aprovando o armazenamento de suas amostras biológicas.

ANÁLISE: PENDÊNCIA NÃO ATENDIDA. No documento "PB_INFORMAÇÕES_BÁSICAS_DO_PROJETO_748663.pdf" de 06/06/2017 lê-se: "Haverá formação de biorrepositório, no qual as amostras coletados dos participantes da pesquisa serão armazenadas PARA USO EM PESQUISAS FUTURAS" (destaque nosso). Assim sendo, conforme solicitado no Parecer Consubstanciado CONEP n 2.057.804 de 11/05/2017, solicita-se apresentar Declaração de que toda nova pesquisa a ser realizada com o material armazenado em biorrepositório será submetida para aprovação do Comitê de Ética em Pesquisa (CEP) institucional e, quando for o caso, da Comissão Nacional de Ética em Pesquisa (CONEP) (Item 2.III da Resolução CNS nº 441 de 2011).

RESPOSTA: Foi incluída declaração de que toda nova pesquisa a ser realizada com o material armazenado em biorrepositório será submetida para aprovação do Comitê de Ética em Pesquisa

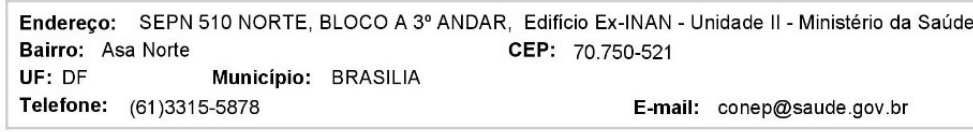




\section{COMISSÃO NACIONAL DE ÉTICA EM PESQUISA}

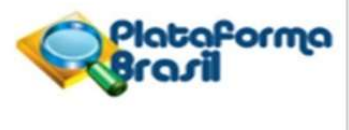

Continuaçäo do Parecer: 2.183.633

(CEP) institucional e, quando for o caso, da Comissão Nacional de Ética em Pesquisa (CONEP). Documento DeclaracaoBiorrep.docx

ANÁLISE: PENDÊNCIA ATENDIDA.

4.3. Regulamento dos laboratórios envolvidos no armazenamento do material biológico: detalhamento operacional e de infraestrutura, bem como as condições de armazenamento do material, que podem estar contidas no projeto de pesquisa detalhado ou em forma de declaração. Cabe ressaltar que o prazo de armazenamento de material biológico humano em biorrepositório deve estar de acordo com o cronograma da pesquisa correspondente e pode ser autorizado por até dez anos.

RESPOSTA: Foram anexados documentos para criação de biorrepositório, junto com os TCLEs que serão assinados pelos participantes da pesquisa aprovando o armazenamento de suas amostras biológicas.

ANÁLISE: PENDÊNCIA ATENDIDA.

4.4. Termo de Acordo em Pesquisa envolvendo mais de uma instituição, se pertinente, contemplando formas de operacionalização, compartilhamento e utilização do material biológico humano armazenado no Biorrepositório, inclusive a possibilidade de dissolução futura da parceria e a consequente partilha e destinação dos dados e materiais armazenados.

RESPOSTA: Foram anexados documentos para criação de biorrepositório, junto com os TCLEs que serão assinados pelos participantes da pesquisa aprovando o armazenamento de suas amostras biológicas.

ANÁLISE: PENDÊNCIA ATENDIDA.

4.5. No cadastro do Protocolo de Pesquisa na Plataforma Brasil, documento "PB_INFORMAÇÕES_BÁSICAS_DO_PROJETO_748663.pdf" de 28/03/2017, foi informado que não haverá retenção de amostras para armazenamento em banco. O termo "banco" é equivocadamente interpretado como "biobanco", quando, na realidade, aplica-se tanto a biobanco quanto a biorrespositório. Assim, sempre que houver coleta de material biológico em uma pesquisa, este campo da Plataforma Brasil deverá ser assinalado com a opção "SIM". Solicita-se adequação.

RESPOSTA: Foram anexados documentos para criação de biorrepositório, junto com os TCLEs que serão assinados pelos participantes da pesquisa aprovando o armazenamento de suas amostras biológicas.

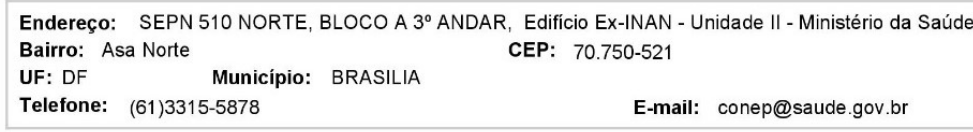




\section{COMISSÃO NACIONAL DE ÉTICA EM PESQUISA}

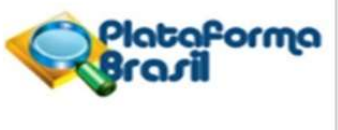

Continuação do Parecer: 2.183 .633

ANÁLISE: PENDÊNCIA ATENDIDA.

5. No documento "ProjetoPabloMocoV3.docx" postado em 28/03/2017 lê-se: "Os equipamentos utilizados já estão disponíveis nas instalações da INSTITUIÇÃO COLABORADORA, Fundação Hemocentro de Ribeirão Preto" (destaque nosso):

5.1 Solicita-se que o centro Fundação Hemocentro de Ribeirão Preto seja incluido no campo "Instituição Coparticipante", Aba 5 (Outras Informações) da Plataforma Brasil. Sua inclusão é necessária para que, após a aprovação da projeto, o protocolo seja enviado para o respectivo CEP responsável.

RESPOSTA: A Fundação Hemocentro de Ribeirão Preto foi adicionada como co-participante. O Comitê de Ética responsável pela Fundação Hemocentro é o CEP do Hospital das Clínicas da Faculdade de Medicina de Ribeirão Preto, no qual o projeto já foi aprovado (CAAE 65063217.4.0000.5440, Parecer número 1.996.240). O parecer consubstanciado do CEP foi anexado.

ANÁLISE: PENDÊNCIA ATENDIDA.

5.2 Solicita-se apresentar Termo de Anuência da instituição coparticipante.

RESPOSTA: Foi anexado o Termo de anuência da Instituição co-participante.

ANÁLISE: PENDÊNCIA ATENDIDA.

5.3. Não foram anexadas as declarações de infraestrutura do Laboratório de Biotecnologia do Hemocentro de Ribeirão Preto e do Hemocentro de Ribeirão Preto para o desenvolvimento da pesquisa. Solicita-se adequação, conforme Norma Operacional CNS n 001 de 2013, item 3.3.h.

RESPOSTA: Foi anexado a declaração de infraestrutura da Fundação Hemocentro de Ribeirão Preto onde está localizado o Laboratório de Biotecnologia.

ANÁLISE: PENDÊNCIA ATENDIDA.

Considerações Finais a critério da CONEP:

Diante do exposto, a Comissão Nacional de Ética em Pesquisa - Conep, de acordo com as atribuições definidas na Resolução CNS n 466 de 2012 e na Norma Operacional nº 001 de 2013 do CNS, manifesta-se pela aprovação do projeto de pesquisa proposto.

Situação: Protocolo aprovado.

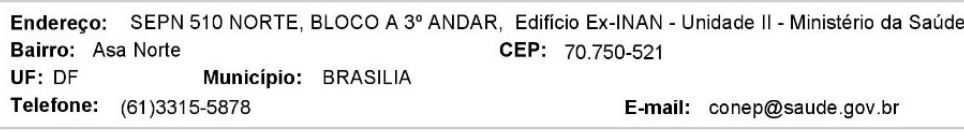




\section{COMISSÃO NACIONAL DE PloEoformo ÉTICA EM PESQUISA \\ Brasi}

Continuação do Parecer: 2.183.633

Este parecer foi elaborado baseado nos documentos abaixo relacionados:

\begin{tabular}{|c|c|c|c|c|}
\hline Tipo Documento & Arquivo & Postagem & Autor & Situação \\
\hline $\begin{array}{l}\text { Informações Básicas } \\
\text { do Projeto }\end{array}$ & $\begin{array}{l}\text { PB_INFORMAÇÕES_BÁSICAS_DO_P } \\
\text { ROJETO 748663.pdf }\end{array}$ & $\begin{array}{c}18 / 07 / 2017 \\
18: 32: 15\end{array}$ & & Aceito \\
\hline Outros & CartaRespostaAssinada.pdf & $\begin{array}{c}18 / 07 / 2017 \\
18: 31: 51 \\
\end{array}$ & Pablo Diego Moço & Aceito \\
\hline Outros & CartaResposta.docx & $\begin{array}{c}18 / 07 / 2017 \\
14: 05: 56 \\
\end{array}$ & Pablo Diego Moço & Aceito \\
\hline $\begin{array}{l}\text { TCLE / Termos de } \\
\text { Assentimento / } \\
\text { Justificativa de } \\
\text { Ausência }\end{array}$ & TCLEPacientesV5.doc & $\begin{array}{c}18 / 07 / 2017 \\
14: 05: 37\end{array}$ & Pablo Diego Moço & Aceito \\
\hline $\begin{array}{l}\text { TCLE / Termos de } \\
\text { Assentimento / } \\
\text { Justificativa de } \\
\text { Ausência }\end{array}$ & TCLEDoadorSaudavelV5.doc & $\begin{array}{c}18 / 07 / 2017 \\
14: 05: 26\end{array}$ & Pablo Diego Moço & Aceito \\
\hline $\begin{array}{l}\text { Declaração de } \\
\text { Pesquisadores }\end{array}$ & DeclaracaoBiorrep.docx & $\begin{array}{c}18 / 07 / 2017 \\
14: 05: 10 \\
\end{array}$ & Pablo Diego Moço & Aceito \\
\hline $\begin{array}{l}\text { Declaração de } \\
\text { Pesquisadores }\end{array}$ & DeclaracaoBiorrep.pdf & $\begin{array}{c}13 / 07 / 2017 \\
11: 03: 17 \\
\end{array}$ & Pablo Diego Moço & Aceito \\
\hline Folha de Rosto & folhaderosto_assin.pdf & $\begin{array}{c}06 / 06 / 2017 \\
11: 21: 43 \\
\end{array}$ & Pablo Diego Moço & Aceito \\
\hline $\begin{array}{l}\text { Declaração de } \\
\text { Manuseio Material } \\
\text { Biológico / } \\
\text { Biorepositório / } \\
\text { Biobanco } \\
\end{array}$ & biorrepositorio_assin.pdf & $\begin{array}{c}31 / 05 / 2017 \\
18: 55: 14\end{array}$ & Pablo Diego Moço & Aceito \\
\hline $\begin{array}{l}\text { Declaração de } \\
\text { Instituição e } \\
\text { Infraestrutura } \\
\end{array}$ & Termo_anuencia_assin.pdf & $\begin{array}{c}31 / 05 / 2017 \\
18: 54: 39\end{array}$ & Pablo Diego Moço & Aceito \\
\hline $\begin{array}{l}\text { Projeto Detalhado / } \\
\text { Brochura } \\
\text { Investigador }\end{array}$ & ProjetoPabloMocoV4.docx & $\begin{array}{c}31 / 05 / 2017 \\
18: 54: 22\end{array}$ & Pablo Diego Moço & Aceito \\
\hline $\begin{array}{l}\text { Declaração de } \\
\text { Instituição e } \\
\text { Infraestrutura }\end{array}$ & infraestrutura_assin.pdf & $\begin{array}{c}31 / 05 / 2017 \\
18: 54: 01\end{array}$ & Pablo Diego Moço & Aceito \\
\hline Outros & AssAprovOrc.pdf & $\begin{array}{c}22 / 02 / 2017 \\
15: 07: 20 \\
\end{array}$ & Pablo Diego Moço & Aceito \\
\hline Cronograma & Cronograma.docx & $\begin{array}{c}14 / 02 / 2017 \\
15: 32: 14 \\
\end{array}$ & Pablo Diego Moço & Aceito \\
\hline Orçamento & OrcamentoPabloMoco.docx & $\begin{array}{c}14 / 02 / 2017 \\
15: 24: 20 \\
\end{array}$ & Pablo Diego Moço & Aceito \\
\hline
\end{tabular}

Situação do Parecer:

Aprovado

Endereço: SEPN 510 NORTE, BLOCO A $3^{\circ}$ ANDAR, Edifício Ex-INAN - Unidade II - Ministério da Saúde Bairro: Asa Norte CEP: $70.750-521$

UF: DF Município: BRASILIA

Telefone: (61)3315-5878

E-mail: conep@saude.gov.br 


\section{COMISSÃO NACIONAL DE Platoformo ÉTICA EM PESQUISA

Continuaçäo do Parecer: 2.183.63

BRASILIA, 25 de Julho de 2017

Assinado por:

Jorge Alves de Almeida Venancio

(Coordenador)

Endereço: SEPN 510 NORTE, BLOCO A $3^{\circ}$ ANDAR, Edificio Ex-INAN - Unidade II - Ministério da Saúde

Bairro: Asa Norte

UF: DF Município: BRASILIA CEP: $70.750-521$

Telefone: (61)3315-5878

E-mail: conep@saude.gov.br

Pàgina 16 de 16 


\section{ANEXO C - Parecer da CIBio}

Ribeirão Preto, 17 de dezembro de 2015.

$\mathrm{O}$ projeto de pesquisa intitulado "Expansão de células dfo sistema imune geneticamente modificadas com vetor CAR anti CD19 ", em nome de Virgínia Picanço e Castro, orientada pelo Dr Dimas Tadeu Covas, foi avaliado pela Comissão Técnica Nacional de Biossegurança (CTNBio), recebendo o parecer APROVADO e registrado sob número de processo: 297/2015.010-02.

Lembramos que deverá ser apresentado a CIBio, o relatório final da pesquisa.

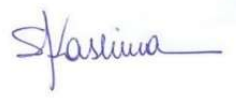

Simone Kashima Haddad

Presidente da CIBio

Fundação Hemocentro de Ribeirão Preto

FH.1.17-REV. 1 RUA TEN. CATÃO ROXO 2501 - CEP 14051-140 - RIBEIRÃO PRETO - SP - PABX: (16) 2101-9300 - FAX: (16) 2101-9309 CNPJ $60.255 .791 / 0001-22$ - INSCR. EST. : ISENTA 